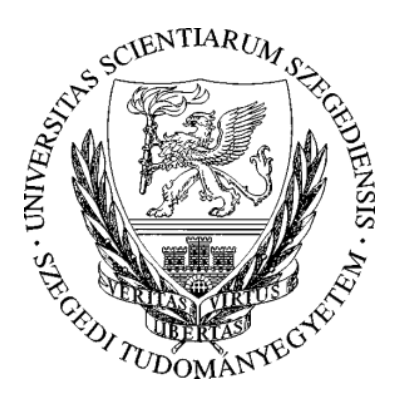

\title{
A szeléntoxicitás és nitro-oxidatív stressz kapcsolatának vizsgálata különböző növényfajokban
}

$\mathrm{PhD}$ értekezés

Molnár Árpád

Témavezetö:

SZTE TTIK

Ördögné Dr. Kolbert Zsuzsanna

Biológia Doktori Iskola

Egyetemi docens

Növénybiológiai Tanszék

2020

Szeged 


\section{Tartalomjegyzék}

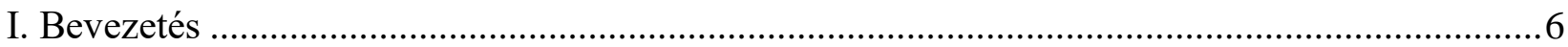

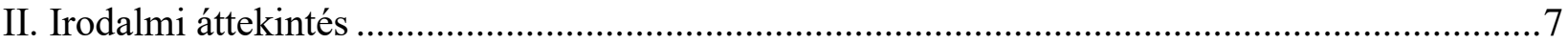

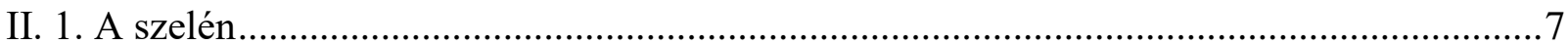

II. 2. A szelén metabolizmusa a magasabbrendü növényekben …………………………….......7

II. 3. A szelén szerepe a növényekben.................................................................................10

II. 4. Toleranciamechanizmusok növényekben .......................................................................14

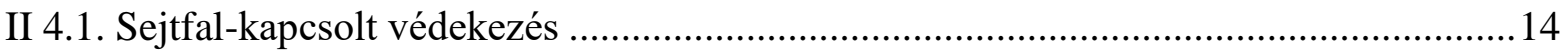

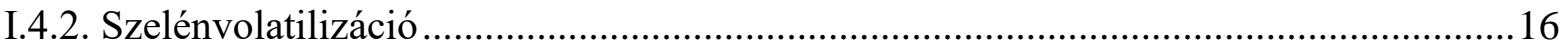

II. 5. Reaktív oxigénformák (ROF) ……………………......................................................17

II. 6. Reaktív nitrogénformák (RNF) ..................................................................................21

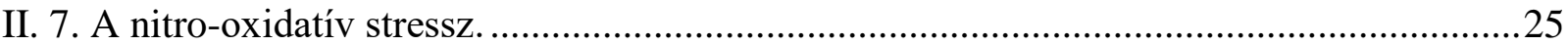

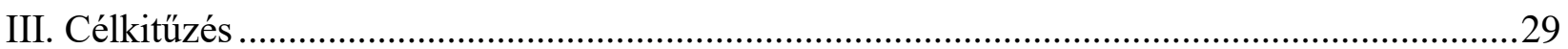

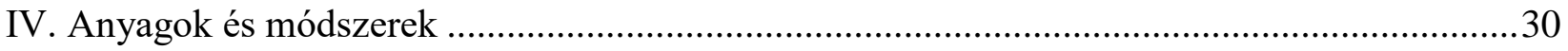

IV. 1. Növényi anyag és nevelési körülmények a különbözö rendszerekben .............................30

IV 1.1. Különböző szelénformákat összehasonlító kísérletek ................................................30

IV 1.2. Különböző szelénérzékenységü növényfajok összehasonlítása ...................................30

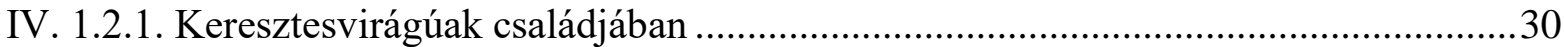

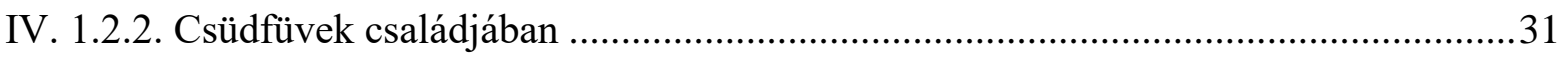

IV. 2. Csírázás, biomassza-produkció és sztómamüködés vizsgálata ..........................................31

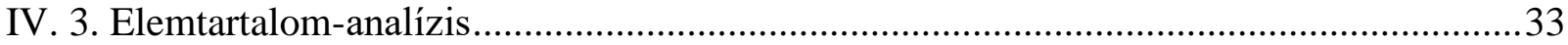

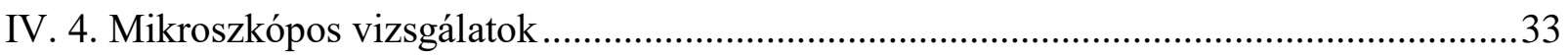

IV 4.1. Nem fluoreszcens mikroszkópos technikák...............................................................33

IV 4.2. Fluoreszcens mikroszkópos technikák......................................................................

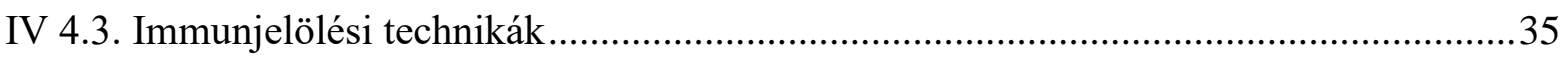

IV 4.4. A festési technikák mikroszkópos háttere ……………………………………..........36

IV. 5. Proteintirozin-nitráció vizsgálata western blot analízissel ..................................................38

IV. 6. Natív gélelektroforézishez kapcsolható módszerek .........................................................39

IV. 7. Spektrofotometriai vizsgálatok.....................................................................................

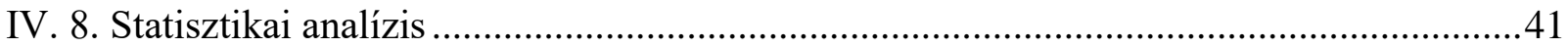




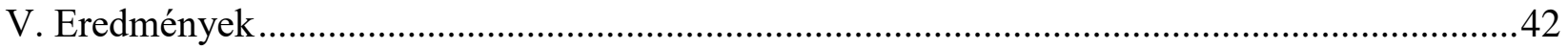

V. 1. Különböző szelénformákat összehasonlító kísérletek .......................................................42

V. 2. Különböző szelénérzékenységü növények összehasonlítása a keresztesvirágúak

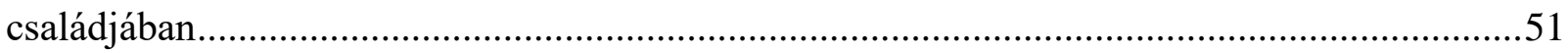

V. 3. Különböző szelénérzékenységü növények összehasonlítása a csüdfüvek családjában .....62

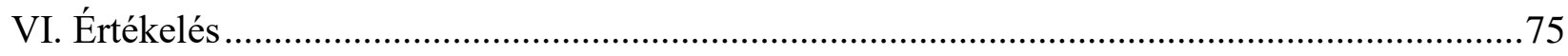

VI. 1. Különböző szelénformákat összehasonlító kísérletek ………………………………......75

VI. 2. Különböző szelénérzékenységü növények összehasonlítása a keresztesvirágúak

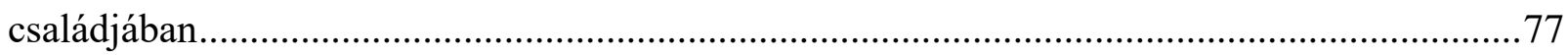

VI. 3. Különböző szelénérzékenységủ növények összehasonlítása csüdfüvek családjában .......80

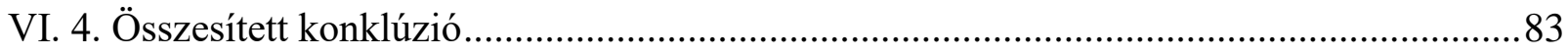

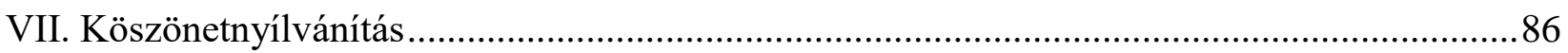

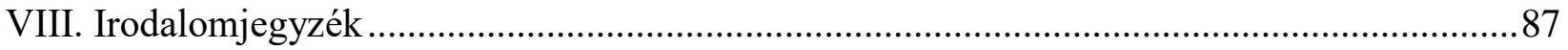

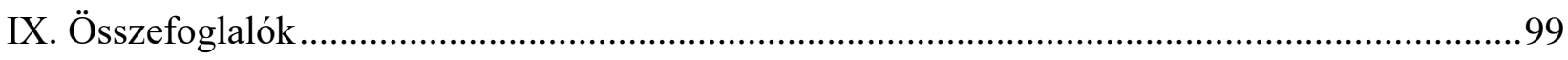

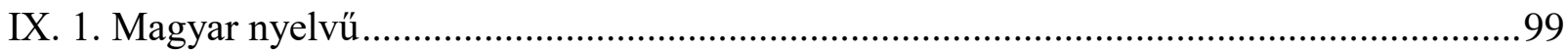

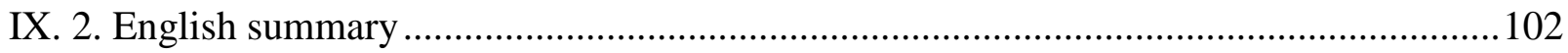

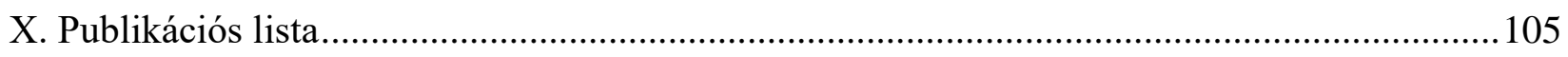

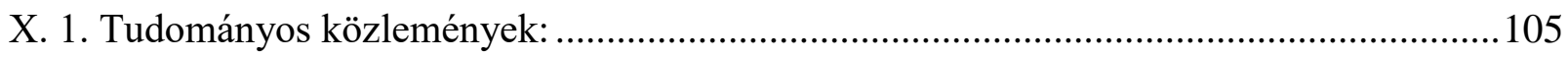

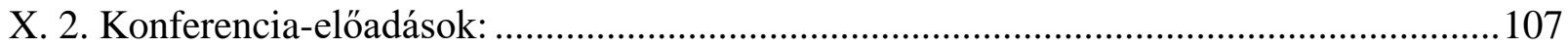

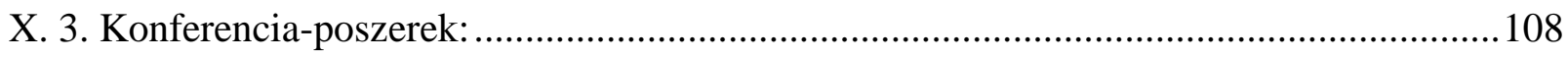




\section{Rövidítések jegyzéke}

AA -aszkorbát

ABRE-abszcizinsav válasz elem

Amplex Red-10-acetil-3,7-

dihidroxifenoxazin

APR-adenozin-foszfoszulfát reduktáz

APS-ATP szulfuriláz

APSe-adenozin-foszfoszelenát

APX -aszkorbát peroxidáz

CCCP-karbonil-cianid-m-klór-fenil-hidrazon

$\mathrm{CO}_{3}{ }^{-}-$-karbonát gyökanion

DAF-FM DA-4-amino-5-metilamino-2', 7'difluorofluoreszcein diacetát

DHA -dehidroaszkorbát

DHAR -dehidroaszkorbát reduktáz

DHE-dihidroetítium

DHR-dihidrorodamin 123

DMDSe-dimetildiszelenid

DMSe-dimetilszelenid

DMSeP-dimetildiszelenopropionát

EDTA-etilén-diamin-tetraecetsav

FDA-fluoreszcein-diacetát

FITC-fluoreszcein-izotiocianát

GPX -glutation peroxidáz
GR-glutation reduktáz

GSH -redukált glutation

GSH-Px-glutation-peroxidázok

GSNO -S-nitrozoglutation

GSNOR-S-nitrozoglutation reduktáz

GSSG -oxidált glutation

$\mathrm{H}_{2} \mathrm{O}_{2}$-hidrogén-peroxid

HAST- nagy affinitású szulfát transporter (high affinity sulphate transporter)

$\mathrm{HO}$-hidroxilgyök

HPCA1-hidrogén-peroxid-indukált $\mathrm{Ca}^{2+} 1$

$\mathrm{K}_{2} \mathrm{~S}_{2} \mathrm{O}_{5}$-kálium-metabiszulfit

KCl-kálium-klorid

MAPK-mitotikus aktivátor protein kináz

MBB-mono-bromo-bimán

MDHA -monodehidroaszkorbát

MDHAR -monodehidroaszkorbát reduktáz

MES-2-(N-Morfolino)-etán-szulfonsav

MeSeCys-metilszelenocisztein

MeSeMet-metilszelenometionin

$\mathrm{N}_{2} \mathrm{O}_{3}$-dinitrogén-trioxid

$\mathrm{Na}_{2} \mathrm{SeO}_{3}$-nátrium-szelenit

$\mathrm{Na}_{2} \mathrm{SeO}_{4}$-nátrium-szelenát 
NBT-nitro-kék-tetrazólium

NifS-cisztein-deszulfuráz proteinek

NO-nitrogén-monoxid

$\mathrm{NO}^{+}$-nitrozónium kation

$\mathrm{NO}^{-}$-nitroxil anion

$\mathrm{NO}_{2}$-nitrogén-dioxid

$\mathrm{NO}_{2}$-BSA-nitrált borjú szérum albumin

$\mathrm{NO}_{2}^{-}$-nitrit

$\mathrm{NO}_{3}{ }^{-}$-nitrát

NOFNiR-NO-formáló nitrit-reduktáz

NOS-arginin dependens NO-szintáz

NR-nitrát reduktáz

$\mathrm{O}_{2}{ }^{\circ-}$-szuperoxid gyökanion

OAS-O-acetilszerin

OASTL-O-acetilszerin tiol liáz

$\mathrm{ONOO}^{-}$-peroxinitrit

$\mathrm{ONOOCO}_{2}^{-}$-nitrozo-peroxikarbonsav

$\mathrm{ONOOH}$-peroxinitrites sav
PHT- foszfát transzporterek

PTN-protein tirozin nitráció

PVDF- Polivinilidén-fluorid

RNF-reaktív nitrogénformák

ROF-reaktív oxigénformák

$\mathrm{Se}^{0}$-elemi szelén

$\mathrm{Se}^{-2}$-szelenidek

$\mathrm{Se}^{+4}$-szelenitek

$\mathrm{Se}^{+6}$-szelenátok

SeCys-szelenocisztein

SeCysth-szelenocisztationin

SehomoCys-szelenohomocisztein

SeMet-szelenometionin

$\mathrm{SeO}_{3}{ }^{2-}$-szelenit

$\mathrm{SeO}_{4}{ }^{2-}$-szelenát

SNP-nátrium nitroprusszid

SOD -szuperoxid dizmutáz

Tris-Trisz (hidroximetil)-aminometán 


\section{Bevezetés}

Bolygónk történelme során számos változáson esett át, de ennek sebessége általában igen lassú volt az adott bioszféra szempontjából. A jelenleg is tartó folyamatok azonban gyorsuló tendenciát mutatnak, $\mathrm{s}$ ennek hátterében az állhat, hogy a természetes folyamatok mellett az antropogén tevékenységek is jelentős befolyással bírnak a környezetre. A környezetszennyezés, ipar, mezőgazdaság hatásai már észrevehetőek a talajokban és felszíni vizekben, s ez alól a nehézfémszennyezés sem kivétel.

A környezet szelén tartalma jelentős változásokon esett át a természetes egyensúlyhoz képest. A szelén átlagos koncentrációja a felszíni vizekben és tengerekben $0,2 \mathrm{mg} / \mathrm{l}$, míg a talajokban $0,4 \mathrm{mg} / \mathrm{kg}$. A Európai Unióban a talajok szelén szennyezettségének határértéke $3 \mathrm{mg} /$ kg, míg Magyarországon ez a határérték $1 \mathrm{mg} / \mathrm{kg}$. Hazánk talajaiban több alkalommal is felmérték a szelén tartalmat. Kádár (1998) a hazai természetvédelmi termőtalajokat vizsgálta, mely szelén tartalma 0,03-2 mg/kg között alakult, néhány kiugró 4-5 mg/kg-os értéket leszámítva a Bükk térségéből. A magyarországi talajok szelén hiányosnak tekinthetőek (Kovács és mtsai., 2008), de az antropogén folyamatok gyorsan megnövelhetik a szelén koncentrációt. A feldúsulás hátterében olyan tevékenységek tevékenységek állnak, mint a szén vagy olaj égetése (0,1-7 $\mathrm{mg} / \mathrm{kg})$, mezőgazdasági foszforműtrágya $(300 \mathrm{mg} / \mathrm{kg})$ és istállótrágya $(2-3 \mathrm{mg} / \mathrm{kg})$ használata, a közlekedés és a környezetszennyezés. A környezetszennyezés jelentőségére ékes példa az egykori Csepeli Vas és Fémmüvekben történt illegális galvániszap lerakás, ahol a talaj felső rétegének szelén tartalma a határérték százszorosára emelkedett.

A talajok szelén tartalmának változása kihatással van az élőlényekre. A legtöbb nehézfémhez hasonlóan, nagyobb mennyiségben a nemfémes szelén is toxikus az élő szervezetek számára, s a növényekben felhalmozódva bejuthat a táplálékláncba, így az állatokra vagy akár az emberre is veszélyt jelent. A szelén toxicitását az elmúlt években számos kutatás vizsgálta már, de a növényekben létrejövő jelátviteli folyamatok még kevésbé ismertek. Munkám során vizsgáltam a szelén terhelés és nitro-oxidatív jelátvitel közötti összefüggést, melynek feltárása elősegítheti a szelénnel kapcsolatos környezeti problémák enyhítését a jövőben. 


\section{Irodalmi áttekintés}

\section{1. $\underline{\text { A szelén }}$}

A szelén egy nemfémes elem, mely esszenciális a baktériumok, algák és állatok számára (Schiavon és Pilon-Smits, 2017). Kémiai tulajdonságai alapján az oxigén csoportba tartozik, vegyjele Se, rendszáma 34, relatív atomtömege pedig 78,96. Oxidációs állapotai alapján négy fö formája létezik a természetben: a szelenidek $\left(\mathrm{Se}^{-2}\right)$, az elemi szelén $\left(\mathrm{Se}^{0}\right)$, a szelenitek $\left(\mathrm{Se}^{+4}\right)$ és szelenátok $\left(\mathrm{Se}^{+6}\right)$. A molekula nagyfokú hasonlóságot mutat a kénnel, így élettani folyamatokban versengés alakulhat ki a kettő között (White és mtsai., 2004), de fontos megemlíteni, hogy a kénnel ellentétben a szelén oxidálódik a biokémiai folyamatok során. A makromolekulákban a kén képes diszulfid hidak kialakítására, melynek nagy szerepe van a proteinek struktúrájában, s ehhez hasonlóan a szelén képes diszelenid hidak kialakítására (Hondal és mtsai., 2013).

A szelén a környezet minden közegében megtalálható, beleértve ebbe a talajt, felszín alatti és feletti vizeket, légkört és az élő szervezeteket is. A talaj szeléntartalma 0,01-2,0 mg/kg közé esik, átlagosan $0,4 \mathrm{mg} / \mathrm{kg}$. Léteznek úgynevezett szelenifer talajok, melyek szeléntartalma igen magas, $1200 \mathrm{mg} / \mathrm{kg}$ is lehet. Az ilyen talajok általában homokkövek és krétakori agyagásványok származékai (Fordyce, 2005; Johnson és mtsai., 2010). A talajokban a legáltalánosabban elöforduló formája az elemi szelén $\left(\mathrm{Se}^{0}\right)$, mely vízoldhatatlan, így alig hasznosítható az élő szervezetek számára (Craig, 1986). A savas kémhatású reduktív tulajdonságú talajokban a leggyakrabban előforduló szelénformák a szelenid és az elemi szelén. A lúgos kémhatású, oxidatív talajokban a szelén elsősorban szelenit $\left(\mathrm{SeO}_{3}{ }^{2-}\right)$ és szelenát $\left(\mathrm{SeO}_{4}{ }^{2-}\right)$ formájában megtalálható, s mindkettő igen jó vízoldékonysággal rendelkezik. A jó vízoldékonyságuk maga után vonja, hogy a vízi környezetekben is ez a két szelénforma dominál, de a szelenit megkötése talajszemcséken csökkentheti a vízben oldott mennyiséget (Martens, 2003). A szelén környezetben lévő mennyiségét sok tényező befolyásolja, ilyenek a természetes (alapkőzet típusa, vulkanikus tevékenység) és antropogén (mezőgazdaság, ipar) faktorok.

\section{2. A szelén metabolizmusa a magasabbrendủ növényekben}

A szelén elérhetőségét a növények számára a talajokban sok tényező befolyásolja, ilyenek a hőmérséklet, kémhatás, redoxpotenciál, víz és szerves anyag tartalom, valamint a mikrobiális 
folyamatok (Skinner 1999; Adriano, 2001). A felvétele a gyökerekbe szelénformától függően több útvonalon történhet, és mivel más anyagcsere utak transzporterei játszanak szerepet, így kompetitív gátlásról beszélhetünk a szulfát és a szelenát vagy a foszfát és a szelenit között. A szelenát felvétele a szulfát transzportereken keresztül történik, melyeket öt csoportra oszthatunk fel, melyek közül az első csoport a legjelentősebb (Hawkesford, 2005). A nagy affinitású szulfáttranszporterek (high affinity sulphate transporter, HAST), mint az Arabidopsis thaliana-ban az AtSultr 1:1, AtSultr 1:2, AtSultr 1:3 katalizálják a szelenát felvétel nagy részét (Kaur és mtsai., 2014). Bizonyított, hogy az ezt a transzporter csoportot nem tartalmazó növények szelénfelvétele jelentősen kisebb (Shibagaki és mtsai., 2002), míg az első csoport HAST transzportereit túltermelő transzgénikus növények jelentős szelénakkumulációra képesek (Terry és mtsai., 2000). A szelenit felvétele a foszfát-transzporterekkel történik, melyet az irodalomban már többen dokumentáltak (Li és mtsai., 2008; Zhang és mtsai., 2014). Megemlítendő továbbá, hogy szelenitre permeábilis egy szilícium influx transzporter is, az OsNIP2;1, mely az aquaporinok nodulin 26-szerü belső membránprotein alcsaládjához tartozik (Zhang és mtsai., 2006). Elméletileg lehetséges a szelenit nem specifikus, passzív felvétele is, de Li és mtsai. (2008) munkájában búzanövények gyökereit kezelték karbonil-cianid-m-klór-fenil-hidrazon (CCCP) metabolizmus gátlószerrel és a kezelés hatására a szelén felhalmozódása is jelentősen csökkent, mely cáfolja a passzív szelenitfelvétel lehetőségét. A szerves szelénformák, mint a szelenometionin (SeMet) és szelenocisztein (SeCys) felvétele aminosav-permeázokon keresztül történik, s összehasonlítva a szervetlen formákkal egyes fajok, mint a durumbúza preferálják a szeleno-aminosavakat (Kikkert és Berkelaar, 2013), míg az indiai mustár inkább a szervetlen formákat akkumulálja nagyobb mértékben (Montes-Bayón és mtsai., 2002).

A szelén transzlokációja a hajtásban szelenát formában gyorsabb, mint szelenit formájában (Arvy 1993; De Souza és mtsai., 1998; Pilon-Smits és mtsai., 1999; Cartes és mtsai., 2005), a transzport a xilémben történik (Zayed és mtsai., 1998). A beépítés a plasztiszok kénasszimilációs útvonalán keresztül valósul meg. A szelenát bejutva a plasztiszba az ATP-szulfuriláz által adenozin-foszfoszelenáttá válik, melyet az adenozin-foszfoszulfát reduktáz szelenitté bont. A szelenit itt lép be a folyamatba, s tovább redukálódik nem enzimatikusan glutation vagy enzimatikusan szulfit-reduktáz segítségével szeleniddé $\left(\mathrm{Se}^{-2}\right)$. A szelenid O-acetilszerinnel (OAS) kapcsolódva szelenociszteint (SeCys) fog eredményezni, s itt a szeleno-aminosavak (SeMet) sorsa elágazik (Kolbert és mtsai., 2019a). A szelenociszteinből létrejöhet szelenometionin, mely a 
volatilizációs detoxifikációs útvonal egyik fontosabb lépése, a folyamat végén dimetil-szelenid (DMSe) keletkezik. A szelenociszteinből metil-szeleno-cisztein keletkezhet, vagy a ciszteindeszulfuráz proteinek (NifS) képesek elemi szelénre és alaninra bontani a szelenociszteint (Van Hoewyk és mtsai., 2005). A szeleno-aminosavak képesek beépülni fehérjékbe, így befolyásolva aktivitásukat. A szelén szöveten belüli speciációja függ a kezelésnél alkalmazott szelénformától, ahogy de Souza és mtsai. (1998) is bizonyították. Kísérleteik során a szelenáttal kezelt indiai mustár föleg szelenátot, míg a szelenittel kezelt inkább SeMet-t és szelenometionin-Se-oxidot halmozott fel. A tárolt szelénforma utalhat a növény szelénakkumulációs képességére is, mivel a hiperakkumuláló Stanleya pinnata és Astragalus bisulcatus inkább metilszelenociszteint és más szerves formákat akkumulálnak (Freeman és mtsai., 2006). Az ok abban keresendő, hogy a szerves szelénformák toxicitása kisebb, mint a szervetlen formáké (Garousi, 2015). A szelén metabolizmusát és transzportját a 1. ábra foglalja össze. 


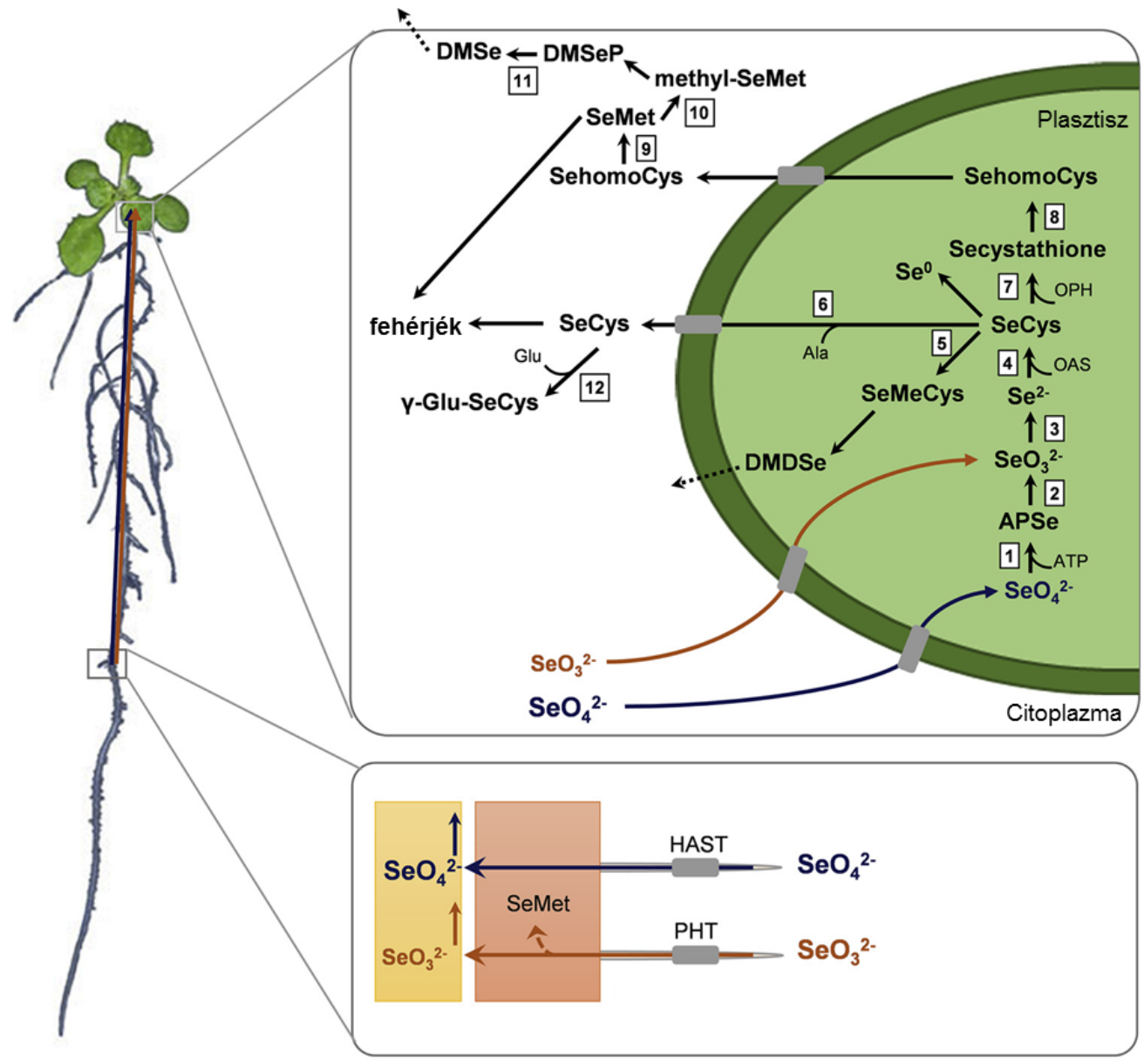

1. ábra A szelén felvétele (a) és metabolizmusa (b) a növényeken belül (Kolbert és mtsai., 2019a alapján). Az ábrán használt rövidítések: szelenit $\left(\mathrm{SeO}_{3}{ }^{2-}\right)$, szelenát $\left(\mathrm{SeO}_{4}{ }^{2-}\right)$, foszfát transzporterek (PHT), szulfát transzporterek (HAST), ATP szulfuriláz (APS), adenozin-foszfoszelenát (APSe), adenozin-foszfoszulfát reduktáz (APR), szelenid $\left(\mathrm{Se}^{2-}\right)$, O-acetilszerin (OAS), O-acetilszerin tiol liáz (OASTL), szelenocisztein (SeCys), szelenocisztationin (SeCysth), metilszelenocisztein (MeSeCys), dimetildiszelenid (DMDSe), szelenohomocisztein (SehomoCys), szelenometionin (SeMet), metilszelenometionin (MeSeMet), dimetildiszelenopropionát (DMSeP), dimetilszelenid (DMSe). Magyarázat a szövegben.

\section{3. A szelén szerepe a növényekben}

A szelén nem esszenciális a magasabbrendü növények számára, $\mathrm{s}$ általánosságban elmondható, hogy kis mennyiségben pozitív hatással bír, míg nagy mennyiségben toxikus (Xue és mtsai. 2001; Germ és mtsai., 2007; Malik és mtsai., 2011). A már korábban említett hiperakkumuláló növények igen nagy mennyiségben raktározhatnak szelént negatív hatások nélkül (Baker és mtsai., 2000); akár $1000 \mathrm{mg} / \mathrm{kg}$ felhalmozására is képesek (Bañuelos és mtsai., 
1997). A Se pozitív hatásai közé soroljuk a növekedésszabályozást, az antioxidáns és a stresszt enyhítő szerepét, valamint az öregedés gátlását. A szelén növekedést elősegítő szerepéről először Singh és mtsai., (1980) számoltak be, ahol $0,5 \mathrm{mg} / \mathrm{kg}$ szelén növelte a terméshozamot és a biomassza-produkciót indiai mustárnál. Ma már hasonló eredmények számos növényfajban bizonyítást nyertek. A kisebb koncentrációjú exogén szelénkezelés búzában, salátában és uborkában is emelte a biomassza-produkciót (Peng és mtsai., 2001; Hawrylak-Nowak, 2015; Haghini és da Silva, 2016). A teacserje biomassza-termelése megkétszereződött szelenit- és szelenátkezelés hatására a kontrollhoz képest (Hu és mtsai., 2001). Összességében elmondható, hogy a szelén-indukált növekedésserkentés részben az anyagcsere sebességének fokozásával (Malik és mtsai., 2011), részben az antioxidáns kapacitás növelésével (Han és mtsai., 2013) magyarázható.

A szelén antioxidáns tulajdonságai is bizonyítottak (Djanaguiraman és mtsai., 2010), s ezek hátterében részben a glutation-peroxidázok (GSH-Px) és thioredoxin reduktázok állhatnak. A GSH-Px antioxidáns szerepe már ismert az irodalom számára (Liu és mtsai., 2010). A már előzőekben leírt, salátán végzett kísérletek folyamán is megnövekedett a GSH-Px enzimek aktivitása, bár itt a tokoferoltartalom és szuperoxid-dizmutáz (SOD) aktivitás is változott. Ezzel részben ellentétes eredmények születtek perjében, ahol bár a GSH-Px aktivitás nőtt, számottevő változás nem állt be a másik két antioxidáns esetében (Hartikainen és mtsai., 2000). Han és mtsai. (2013) szelén-indukált lipidperoxidáció csökkenéséről számoltak be dohány növényekben, ahol a kontrollhoz képest a kezelt növények malondialdehid- (MDA) tartalma 60-80\% volt. Másik lehetséges folyamat a szelén antioxidáns hatásának hátterében a szuperoxid gyökanion $\left(\mathrm{O}_{2}{ }^{-}\right)$nem enzimatikus szelén katalizált átalakítása hidrogén-peroxiddá $\left(\mathrm{H}_{2} \mathrm{O}_{2}\right)$ (Hartikainen és mtsai., 2000; Cartes és mtsai., 2010), SOD enzim nélkül.

A szelén képes abiotikus és biotikus stresszfolyamatok hatásának enyhítésére. A nehézfémek felvételét és hajtásba történő transzlokációját képes gátolni a szelén (DomokosSzabolcsy és mtsai., 2017). A nehézfémek képesek reakcióba lépni a szelénnel nem toxikus szelén-fém komplexeket alkotva (Arnaud és Dael, 2018), de ezek a molekulák még nem lettek kimutatva a növényekben. A fent leírt antioxidáns hatások is hozzájárulnak az abiotikus stressz enyhítéséhez. Paradicsomnövényben a szelénkezelés csökkentette a kadmium-indukált növekedésgátlást, valamint az aszkorbát-peroxidáz (APX) és glutation-reduktáz (GR) enzimek 
aktivitását is növelte (Alves és mtsai., 2020). Handa és mtsai. (2019) tanulmányában az krómkezelt indiai mustárban a szelén csökkentette a $\mathrm{O}_{2}{ }^{-}$és $\mathrm{H}_{2} \mathrm{O}_{2}$ szintet az antioxidáns védelmi rendszeren keresztül. Emelkedett a klorofill és karotinoidok mennyisége, valamint a SOD, kataláz (KAT), GR és más antioxidáns enzimek átíródásának mértéke. Más abiotikus stresszfolyamatok, mint az UV (Golob és mtsai., 2018), magas hő (Malerba és Cerana, 2018), só (Elkelish és mtsai., 2019), szárazság (Jóźwiak és Politycka, 2019) esetében is kimutatták a szelén enyhítő hatását. A szelén védelmi szereppel rendelkezik biotikus stresszorok ellen is. Pilon-Smits (2019) tanulmányában bizonyították a szelénfelhalmozás növényevőket elriasztó hatását. Leírták, hogy az Astragalus bisulcatus föleg a levélszörökben tárolja a szelént (Freeman és mtsai., 2006), mely lehetséges védelmi mechanizmus (Barillas és mtsai., 2012). Olajrepcében a Sclerotinia sclerotiorum patogén gomba ellen a szelén védelmet nyújtott Liu és mtsai (2019) kísérleteiben.

A Se antiszeneszcens hatása is részben az antioxidáns folyamatokhoz kapcsolható. Kimutatták, hogy repce levelében a nátrium-szelenát kezelés hatására a nem fotokémiai kioltás csökkenése elmaradt a levelekben. A szénhidrát- és fehérjetartalom szeneszcencia folyamán csökken, de a kezelés növelte a mennyiségüket, és a levelek megtartották a zöld színüket (Rahmat és mtsai., 2017). A nitrogénhiány-indukált és fiziológiás öregedési folyamat csökkentette a fotoszintetikus apparátus hatékonyságát, melyet a szelénkezelés képes volt kompenzálni. A pozitív hatás hátterében a reaktív oxigén- és nitrogénformák szintjében, valamint az szeneszcenciához kapcsolható gének expressziójában történt változások állhatnak (Hajiboland és mtsai., 2019).

A szeléntöbblet toxikus hatással bír a növények számára (Terry és mtsai., 2000), mely a legföbb modellnövény Arabidopsis thaliana esetében $2 \mathrm{mg} / \mathrm{kg}$ Se-koncentrációnál jelentkezik (Mikkelsen és mtsai., 1989). Az akkumuláció mértékétől függően a növény maradhat tünetmentes (Kabata-Pendias, 2011), amikor csupán a biomassza-termelés csökken, vagy jelentkezhetnek toxikus tünetek, mint a klorózis, nekrózis és a levelek elhalása (Terry és mtsai., 2000). A legjellemzőbb toxikus tünet a fögyökérhossz rövidülése (Chen és mtsai., 2014; Lehotai és mtsai., 2016a), melyből megállapítható a növényi szelén tolerancia index (Fisher és mtsai., 2016; Tamaoki és mtsai., 2008; Van Hoewyk és mtsai., 2008). A szelén toxicitásának hátterében számos molekuláris folyamat található, melyeket az 2. ábrán foglaltam össze Kolbert és mtsai. (2016) alapján. A legjelentősebb makromolekula-károsító folyamat a szelenoproteinek létrejötte 
(Kolbert és mtsai., 2019a). A SeCys és SeMet képes beépülni a fehérjékbe a kéntartalmú párjaik helyére, így megváltoztatva a fehérjék másodlagos szerkezetét (Hondal és mtsai., 2013), enzim esetében az aktív centrum müködési kinetikáját (Kim és Gladyshev, 2005; Hazebrouck és mtsai., 2000) vagy kofaktor kötését (Aldag és mtsai., 2009). A toleráns növényfajok, mint a Stanleya pinnata, rendelkeznek szelenoprotein detoxifikációs útvonalakkal (Sabbagh és Van Hoewyk, 2012). Olajrepcében kimutatták, hogy a SeCys kezelés megnövelte a proteoszómális aktivitást és az ubikvitinált proteinek mennyiségét (Dimkovikj és mtsai., 2015). Ez jelen esetben a szelén tartalmú proteinek $26 \mathrm{~S}$ proteoszómális lebontását jelenti, de az endoplazmatikus retikulum által katalizált protein lebontásnak is szerepe lehet benne (Van Hoewyk, 2016). Az endoplazmatikus retikulumban folyó protein lebontásban a chaperon-kötő fehérje 2 (BIP2) feladata a nem megfelelö konformációjú proteinekhez való kapcsolódás, mely lehetővé teszi a szállításukat a citoszolba lebontásra. A lúdfü bip2-1 mutánsa nem tudott csírázni szelenocisztein kezelés hatására (Sabbagh és Van Hoewyk, 2012), bizonyítva a proteolitikus útvonal szerepét a szelenofehérjék degradációjában.

A szelén felborítja a növények természetes hormonháztartását is, s akkumulációja jelentősen befolyásolja az auxin-, citokinin- és etilénszinteket (Lehotai és mtsai., 2012, 2016b). Van Hoewyk és mtsai. (2008) kimutatták, hogy a szelén indukálja az etilén és jázmonsav jelátvitel génjeit lúdfüben, s az ezen szignalizációs folyamatokban hibás növények jelentős szelénérzékenységgel bírnak a vad-típushoz képes. A makro- és mikroelemek felvétele és asszimilációs útvonalai is károsodást szenvedhetnek a szelénterhelt növényben. A nyomelemek közül legjelentősebben a kén- $(\mathrm{S})$, foszfor- $(\mathrm{P})$, kalcium- $\left(\mathrm{Ca}^{2+}\right)$ és cink- $\left(\mathrm{Zn}^{2+}\right)$ homeosztázis borulhat fel (Filek és mtsai., 2010; Zembala és mtsai., 2010; Hawrylak-Nowak és mtsai., 2015).

A nitro-oxidatív stressz szintén hozzájárul a Se toxicitásához. Mivel kutatómunkám fókuszában a nitro-oxidatív jelátvitel állt, e molekuláris mechanizmusokat a következő fejezetekben részletesen bemutatom. 


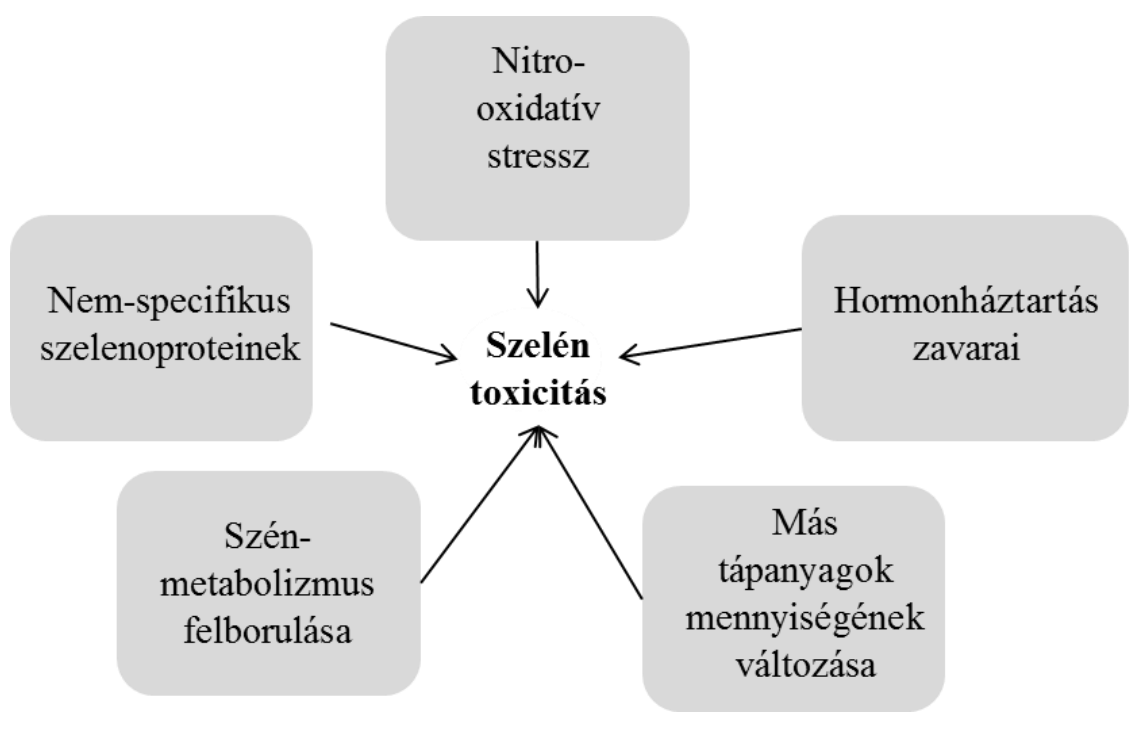

2. ábra A szelén toxicitás hátterében álló legjelentősebb molekuláris folyamatok Kolbert és mtsai. (2016) alapján.

\section{4. Toleranciamechanizmusok növényekben}

\section{4.1. Sejtfal-kapcsolt védekezés}

A növényi sejtfal jelentős szereppel rendelkezik több abiotikus stressz folyamán is (Zhao és mtsai., 2019), de a szeléntöbblet által indukált sejtfalválaszok még kevésbé ismertek. A szelén nem specifikus felvétele és metabolizmusa hasonló egyes nehézfémekhez, így a nehézfémindukált sejtfal-módosulások hasonlóak lehetnek a szelén hatására tapasztalt válaszokkal. A sejtfal egy természetes védelmi vonalként müködik a nehézfémek ellen, s a nehézfémek kizárása a citoplazmából és a sejtfalban történő tárolása már ismert folyamat (Loix és mtsai., 2017). A sejtfal poliszacharidjai képesek a nehézfémek megkötésére és tárolására (Krzeslowska, 2011; Vuletic és mtsai., 2014), de nem szabad elhanyagolni a sejtfalban lévő proteinek, aminosavak és fenolok hatásait sem. A lényege ennek a stratégiának a citoplazmában található érzékeny folyamatok védelme (Tenhaken, 2014), valamint a sejtfalban megkötött nehézfém hatása a növényre jelentősen csökken (Houston és mtsai., 2016).

A két legjelentősebb nehézfém-kötő sejtfalalkotó a pektin és a hemicellulóz (Hossain és mtsai., 2006; Loixés mtsai., 2017). Az alumíniumtöbblet hatására a sejtfalban a bór keresztkötésü 
ramnogalakuronán II tartalmú pektin mennyisége elősegítette az alumínium komplexekben való tárolását, enyhítve a növekedésgátlást és más stresszfolyamatokat (Amenos és mtsai., 2009; Horst és mtsai., 2010). Bizonyított, hogy a külső szilíciumkezelés megnövelte a sejtfal $\mathrm{Zn}^{2+}$-kötését kukoricában, csökkentve intracelluláris koncentrációját és transzlokációját (Vaculik és mtsai., 2009). A sejtfal nehézfém kötésére igen szép példa a közönséges nád, ahol a $\mathrm{Zn}^{2+}$ legnagyobb mértékben az apoplasztban tárolódott, míg a vakólum és citoplazma $\mathrm{Zn}^{2+}$-koncentrációja alacsonyabb volt (Jiang és Wang, 2008). A pektin metilészterifikációs állapota számottevően hozzájárulhat a nehézfémkötéshez (Eticha és mtsai., 2005), de érdemes megjegyezni, hogy endocitózissal az alacsony metilészterifikáltságú pektin nehézfémmel kapcsolódva bejuthat a sejtek citoplazmájába (Krzeslowska és mtsai., 2009; Baluska és mtsai., 2005). A divalens kationok kötése nagymértékben függ a különböző funkciós csoportok számától, mint a hidroxil-, tiol-, vagy karboxil csoportok (Pelloux és mtsai., 2007). Bizonyították, hogy a pektin homogalakturonán frakciója, mely kismértékü metilészterifikációval rendelkezik a szabad karboxilcsoportjain képes nagymennyiségü két- és háromértékü fémion megkötésére (Willats és mtsai., 2006). A nehézfémek képesek megnövelni a pektin szintézisét. Például az alumíniumkezelés hatására a különböző alumíniumérzékenységű rozsfajták sejtfalai más választ adtak. Az érzékeny fajta csökkentette a pektin-bioszintézist, míg ezzel ellentétben a toleráns fajta inkább növelte (El-Monein és mtsai., 2014).

Másik jelentős sejtfalalkotó a nehézfémstressz szempontjából a kallóz. A kallóz egy gyorsan szintetizálható poliszacharid, mely fizikai gátat képez patogénekkel (Luna és mtsai., 2011) vagy épp különböző nehézfémekkel szemben, mint az alumínium, kobalt, nikkel, cink és réz. A kallóz gyors sejfalba épülése képes megakadályozni az ionok citoplazmába jutását, így enyhítve azok toxicitását (Cumming és Taylor, 1990; Eticha és mtsai., 2005). Megemlítendő, hogy a sejtfalon kívül a kallóz a nehézfémek plazmodezmákon keresztüli mobilitását is csökkenti. Kartusch (2003) kísérletei vöröshagymában bizonyították, hogy akár igen kis mennyiségű nehézfém, jelen esetben 2-3 $\mu \mathrm{M}$ réz is elegendő a kallózszintézis indukciójához. Lúdfüben ólom hatására is leírták ugyanezen folyamatot (Krzeslowska és mtsai., 2010).

A harmadik, nehézfém-védelemben jelentős sejtfalalkotó a lignin, melynek szintézise megnövekszik nehézfém többlet hatására. A réz képes volt megnövelni a lignin-bioszintézist végző enzimek aktivitását, név szerint a peroxidázok és lakkázok aktivitását (Claus, 2004). 
Ginzengben hasonló folyamatokat mutattak ki réztöbblet hatására, itt a fenilalanin-ammónia-liáz és fahéjsav-alkohol-dehidrogenáz aktivitása is növekedett (Ali és mtsai., 2006). Mindkét enzim szerepet játszik a ligninszintézisében. Arzénkezelés hatására rizsnövényekben hat különböző, ligninszintézisben szerepet játszó enzim génjének átíródásának növekedését mutatták ki. Mint látható, a lignin jelentős szereppel bír a nehézfémtoleranciában, de a sejtfal-összetétel változása kihat annak rigiditására, így a nehézfém-indukált növekedésgátláshoz is hozzájárul (Le Gall és mtsai., 2015).

\section{I.4.2. Szelénvolatilizáció}

A szelénre specifikus detoxifikációs folyamat a szelénvolatilizáció, ahol a hajtásba jutó szelén a gázcsere-nyílásokon keresztül távozik különböző szerves, illékony formákban. Számos növény képes szelénvolatilizációra, de a legjelentősebbek a keresztesvirágúak és csüdfüvek családjában vannak (Guignardi és Schiavon, 2017). A legnagyobb mért volatilizációs sebességet Terry és mtsai., (1992) mutatták ki, ahol a rizs, brokkoli és káposzta volatilizációs sebessége 200$350 \mu \mathrm{g} \mathrm{Se} / \mathrm{m}^{2}$ levél terület volt. A többi vizsgált növényfaj, mint a bab, saláta vagy vöröshagyma

kevésbé jelentős, $15 \mu \mathrm{g} \mathrm{Se} / \mathrm{m}^{2}$ alatti volatilizációs sebességgel rendelkezett. A volatilizáció sebességére a növény környezetében lévő szelénforma is kihat. de Souza és mtsai. (1999) eredményei alapján a szelenit- és szelenátkezelés dózisa és a volatilizáció között koncentrációfüggő kapcsolat van indiai mustárban. Érdemes megemlíteni, hogy a szelenittel kezelt növények 10-15-ször több szelént volatilizáltak, mint a szelenáttal kezeltek. A szerves szelénformák közül a SeMet és DMSeP ennél is jelentősebb volatilizációs rátával bírtak (Terry és mtsai., 1992), mely hasonlóan alakult, mint a szelénfelhalmozódás a gyökerekben (El-Ramady és mtsai., 2015). A sebességkülönbség azzal magyarázható, hogy a szerves formák közelebb állnak az általánosan volatilizált DMSe formához, így gyorsabb a metabolizmusuk. A hiperakkumuláló növények esetében a szelenocisztein SeMeCys-en keresztül átalakul DMDSe-vé, mely a volatilizálható molekula e növények esetében (Pilon-Smits és Quinn, 2010). A volatilizáció szelénszennyezett területek megtisztítására alkalmas folyamat, de nem szabad elfeledni, hogy a környezetben számos tényezö befolyásolhatja a sebességét, mint például a magas szulfáttartalom csökkentheti a volatilizáció mértékét (Zayed és mtsai., 1998). 


\section{5. Reaktív oxigénformák (ROF)}

A környezet hatással van az élő szervezetekre, s azok is formálják élőhelyüket. A növények helyhez kötött életmódjuk miatt kiváltképp érzékenyek a stresszhatásokra. A különböző abiotikus faktorok, mint a só, szárazság, alacsony hőmérséklet, ultraibolya sugárzás, nehézfémek, biotikus patogének és a szelén többlete is képesek felborítani a ROF metabolizmusát (Xie és mtsai., 2019).

Az oxigén az elektronpályái töltöttsége miatt egy relatív semleges molekula (Elstner, 1987). Az aerob szervezetekben lejátszódó anyagcsere folyamatok során ellenben keletkezhetnek belőle gyökös és nem gyök jellegü reaktív molekulák, a ROF (Hossain és mtsai., 2015). Ezek leggyakoribb formái a $\mathrm{O}_{2}{ }^{--}, \mathrm{H}_{2} \mathrm{O}_{2}$, szinglet oxigén $\left({ }^{1} \mathrm{O}_{2}\right)$ és hidroxilgyök $\left({ }^{\bullet} \mathrm{OH}\right)$ (Xie és mtsai., 2019). Fontos hangsúlyozni, hogy a sejtorganellumokban természetes körülmények között is keletkeznek ROF, sőt egyes élettani folyamatokhoz elengedhetetlenek. Szinte minden sejtszervecskében keletkezhet ROF az elektrontranszport-láncok és metabolikus aktivitás következtében (Xia és mtsai., 2015). Kettőt emelnék ki ezek közül, a kloroplasztiszt és a peroxiszómát. A kloroplasztiszban a PSII képes szinglet oxigén képzésére az I. fotokémiai rendszer (PSI) pedig a Mehler reakción keresztül $\mathrm{O}_{2}{ }^{-}-\mathrm{t}$ termel (Karuppanapandian és mtsai., 2011). A peroxiszómákban jelentős mennyiségü $\mathrm{H}_{2} \mathrm{O}_{2}$ keletkezik a flavin-oxidázok aktivitása során (del Ríó és mtsai, 2006; Palms és mtsai., 2009). Felmerülhet a kérdés, hogy mi a jelentőségük természetes körülmények között a sejtekben. Példaképp a $\mathrm{H}_{2} \mathrm{O}_{2}$-nak szerepe van a sztómamozgásban (Rodrigues és mtsai., 2017), a stresszalkalmazkodásban (Lv és mtsai., 2018), a sejtciklusban (Pokora és mtsai., 2017), a fotoszintézisben (Exposito-Rodriguez és mtsai., 2017), a sejtfal-rigiditásban (Li és mtsai., 2017), a szeneszcenciában (Jajic és mtsai., 2015) és az antioxidáns védelmi rendszerre is hatással van (Liu és mtsai., 2016).

A ROF termelődése és kioltása között egy folyamatos egyensúlyi állapot áll fent, melyet az őket semlegesítő antioxidáns védelmi rendszer biztosít (Caverzan és mtsai., 2016). A környezeti faktorok változása, valamint a stresszfolyamatok felboríthatják a ROF metabolizmusát. A folyamatot régebben oxidatív stresszként említették, mivel csupán a makromolekula-károsító hatása volt bizonyított. Az újabb eredmények alapján Foyer és mtsai. (2017) az oxidatív jelátvitel fogalmat javasolták, mivel a ROF fontos szerepet tölt be a védelmi válasz jelátvitelében is. 
Növényi enzimek, mint a peroxidázok és NADPH oxidáz szintén képesek ROF termelésre, s e molekulák koncentrációinak gyors emelkedése az oxidatív robbanás (Sharma és mtsai., 2012).

A legtöbb abiotikus stressz kiváltja az oxidatív jelátvitelt növényekben, mivel valamilyen prooxidáns vagy elektrontranszportlánc-gátló hatással rendelkeznek (Schützendübel és Polle, 2002). A természetesen termelődő ROF egyensúly felborulása pedig makromolekula-károsodást vonhat maga után. Az oxidatív károsodás leggyakrabban vizsgált biomarkere a lipidperoxidáció, ami a membránlipidek zsírsavoldalláncait érinti (Diezt és mtsai., 1999). A reakció iniciációs fázisában a többszörösen telítetlen zsírsavoldallánc egy ${ }^{\bullet} \mathrm{OH}$-el vagy $\mathrm{O}_{2}{ }^{-}$-al lép reakcióba, zsírsav-gyököt eredményezve (Smirnoff, 1995). Ez a folyamat képes láncreakcióként végighaladni a membránon, megváltoztatva annak fluiditását és permeabilitását, valamint az integrált membránproteinek funkcióját. A súlyos lipidperoxidáció sejthalállal végződik (Sharma és mtsai., 2012). A lipideken kívül más makromolekulák is károsodnak az oxidatív stressz során. A proteinek aktív centruma, töltése, kofaktorok redox állapota, valamint a molekula szerkezete is jelentős változásokat szenvedhet el oxidatív károsodások hatására. Az ilyen molekulákat a sejtek képesek lebontani és újonnan szintetizált proteinekkel helyettesíteni, akár a fotoszintézis D1 fehérjéje esetén, de nagyobb mennyiségben ez a károsodás igen jelentős lehet. A nukleinsavak is károsodhatnak a ROF által, mely olyan számottevő módosításokat okozhat, mint a báziscsere, kettősszál-törés vagy deléció. A DNS oxidatív károsodásait nehezebb javítani, így jóval kisebb mértékben is indukálhatja a sejthalált (Tuteja és mtsai., 2010).

A növények helyhez kötött életmódjukból adódóan gyakran szenvednek valamilyen abiotikus stresszfaktor hatásait, így nem meglepö, hogy a növényi sejt antioxidáns védelmi mechanizmusai komplexebbek, mint az állati sejté (Scandalios 1997). Az ROF-metabolizmus kiegyenlítésére és az oxidatív makromolekula-károsodások megakadályozására alakult ki az antioxidáns védelmi rendszer, melyet két csoportra oszthatunk: enzimatikus és nem enzimatikus antioxidánsok. Az enzimatikus antioxidánsok közé tartozik a KAT (EC 1.11.1.6.), a GR (EC 1.6.4.2.), az APX (EC 1.11.1.11.), a SOD (EC 1.15.1.1.), a dehidroaszkorbát-reduktáz (DHAR, EC 1.8.5.1.), a gvajakol-peroxidáz (GPX, EC 1.11.1.7.) és a monodehidroaszkorbát-reduktáz (MDHAR, EC 1.6.5.4.) (De Vos és mtsai., 1992; Wang és mtsai., 2004; Lombardi és Sebastiani, 2005). A nem enzimatikus antioxidánsokat oldékonyságuk alapján két csoportra osztjuk: zsíroldékony és vízoldékony antioxidánsok. A legfontosabbak ezek közül a tokoferol, azaz E- 
vitamin és a flavonoidok, melyek fontosak a membránok védelmében. A vízoldékony antioxidánsok közül az aszkorbát, valamint a glutation a legfontosabbak (Drazkiewicz és mtsai., 2003). Az antioxidáns védelmi rendszer és ROF kapcsolatait az 3. ábrán mutatom be, míg a növényi sejtekben való eloszlásuk a 4. ábrán látható.

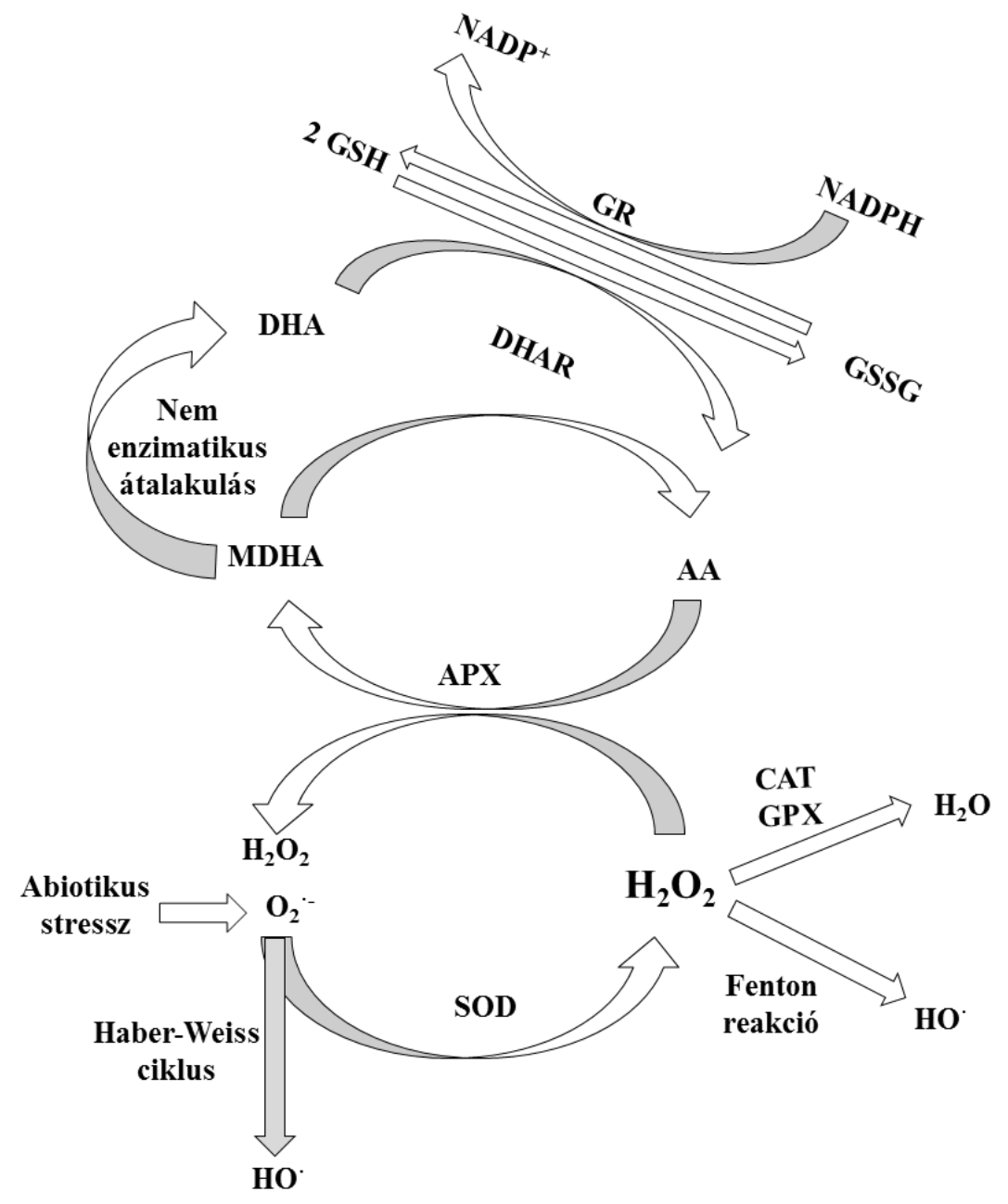

3. ábra Az antioxidáns védelmi rendszer kapcsolatai, valamint az általuk katalizált reakciók Tuteja és mtsai. 2010 alapján. Rövidítések: szuperoxid gyökanion $\left(\mathrm{O}_{2}{ }^{-}\right)$, hidroxilgyök $\left(\mathrm{HO}{ }^{\bullet}\right)$, hidrogén-peroxid $\left(\mathrm{H}_{2} \mathrm{O}_{2}\right)$, oxidált glutation (GSSG), redukált glutation (GSH), glutation peroxidáz (GPX),szuperoxid-dizmutáz (SOD), aszkorbát-peroxidáz (APX), aszkorbát (AA), monodehidroaszkorbát (MDHA), dehidroaszkorbát (DHA), monodehidroaszkorbátreduktáz(MDHAR), dehidroaszkorbát reduktáz (DHAR), glutation-reduktáz (GR) . 


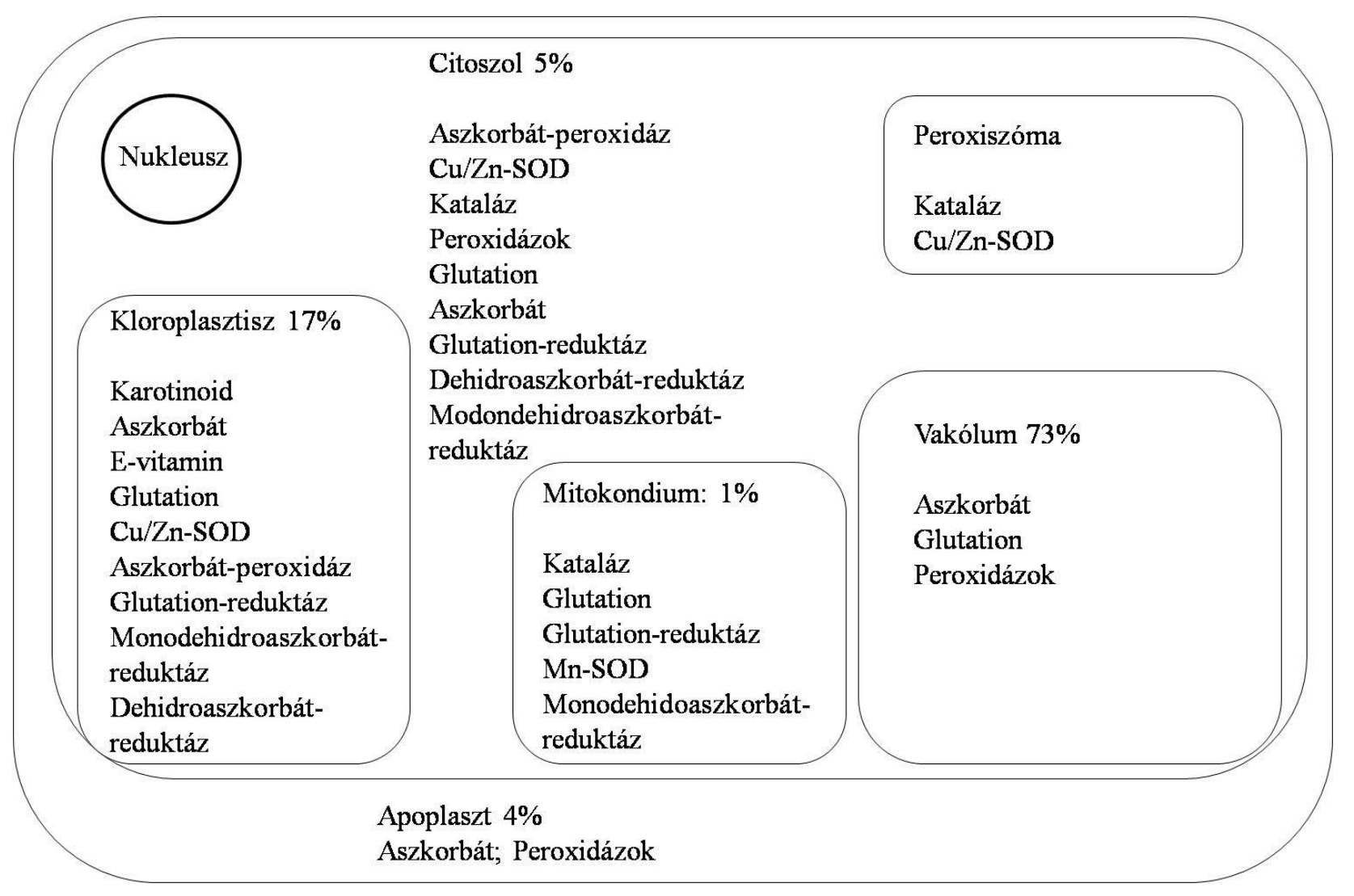

4. ábra Az antioxidáns védelmi rendszer eloszlása a növényi sejteken belül kontroll körülmények között (Scandalios és mtsai., 2005 alapján)

Az oxidatív jelátvitel és ROF érzékelése több különböző molekuláris jelátviteli folyamaton keresztül valósul meg, bár nemrég kimutattak egy specifikus receptor fehérjét is. A $\mathrm{H}_{2} \mathrm{O}_{2}$-indukált intracelluláris $\mathrm{Ca}^{2+}$-felszabadulás zárósejtekben régről ismert (Price, 1990), de a receptor $\mathrm{Wu}$ és mtsai. (2020) kutatásáig ismeretlen volt. A kísérleteik szerint a $\mathrm{H}_{2} \mathrm{O}_{2}$-t a sejtmembrán extracelluláris részén lévő HPCA1 (hidrogén-peroxid indukált $\mathrm{Ca}^{2+} 1$ ) fehérje érzékeli. A protein egy leucinban gazdag ismétlődéseket tartalmazó receptor kináz, melynek extracelluláris oldalán cisztein aminosavak találhatóak, így képes érzékelni a molekulát, mely a zárósejtek $\mathrm{Ca}^{2+}$ csatorna nyitását okozza. A sejt a redox homeosztázist különböző fehérjék tiolcsoportjain keresztül érzékeli, melyek trankripciós faktorokon keresztül aktiválják a védelmi rendszert. Az AP 1 és NF- $\mathrm{B}$ trankszripciós faktorok aktiválódnak a redoxváltozás hatására, és abszcizinsav-válasz elemhez (ABRE) kötődve stresszhez kapcsolt gének átíródását kezdeményezik (Dalton és mtsai., 1999). Megemlítendő, hogy a redukált glutation (GSH)/oxidált glutation (GSSG) is hasonló funkcióval bír. Ennek változása jó indikátora a sejt redoxhomeosztázisának (Foyer és Noctor, 2011). Az oxidatív stressz szignalizációja megvalósulhat 
még továbbá a mitogén-aktivált protein-kinázok aktivátor protein kináz (MAPK) kaszkádon keresztül is (Zhang és Klessing, 2001).

A szelén képes prooxidánsként viselkedni, indukálva az oxidatív stresszt. A citoplazmában a szelenit gyorsan reakcióba lép glutationnal, és szeleniddé alakul, $\mathrm{s}$ a reakció során $\mathrm{O}_{2}{ }^{--}$szabadul fel (Chen és mtsai., 2007). Ez a folyamat aktiválja az antioxidáns védelmi rendszert (Dimkovikj és Van Hoewyk, 2014), valamint az antioxidáns védelmi rendszer transzkripcióját (Van Hoewyk és mtsai., 2008). A nagyobb mennyiségü szelénkezelés képes kimeríteni a glutationrendszert és így megváltoztatni a sejt redox állapotát (Hugouvieux és mtsai., 2009; Grant és mtsai., 2011). A hosszú távon okozott oxidatív károsodások jól leírtak az irodalomban (Geoffery és mtsai., 2007; Freeman és mtsai., 2010; Grant és mtsai., 2011), és nem különböznek jelentősen más abiotikus stressz által okozott gátló hatásoktól. Vallentine és mtsai. (2014) kimutatták, hogy a szelén képes megnövelni a mitokondriális $\mathrm{O}_{2}{ }^{-}$-tartalmat, mely kihat az elsődleges metabolizmusra, de hatással lehet a kloroplasztiszban található vas-kén komplexeket tartalmazó proteinekre is (Fisher és mtsai., 2016).

\section{6. Reaktív nitrogénformák (RNF)}

A nitrogén-monoxid (NO) az elsőként felfedezett gáz halmazállapotú jelátviteli molekula (Palmer és mtsai., 1987). A szerepét és sokszínűségét jól bizonyítja, hogy 1992-ben a Science folyóirat az év molekulájává választotta, valamint Robert F. Furchgott, Louis J. Ignarro és Ferid Murad élettani és orvostudományi Nobel-díjat kapott 1998-ban az élettani hatásainak és jelátvitelének felfedezéséért.

Az NO egy kétatomos szabadgyök, 30,006 g/mol-os molekulasúllyal rendelkezik, mely relatíve kicsi. Erősen lipofil, így igen jó diffúziós értékekkel rendelkezik a plazmamembránokon keresztül (Goretski és Hollocher, 1988). Az átlagos féléletideje 2-30 s között változik (Safia és Asif, 2011), de kis koncentrációban ez számottevően megnőhet (Stöhr és Ullrich, 2002), mely ideális jelátviteli molekulává teszi. A kémiai tulajdonságát tekintve a molekulák közötti kettős kötés egy páratlan elektront eredményez a $2 p-\pi$ pályán. Ezen elektron eltávolításával nyerhető a nitrozónium kation $\left(\mathrm{NO}^{+}\right)$, míg az elektronfelvétel nitroxil aniont $\left(\mathrm{NO}^{-}\right)$eredményez. Az $\mathrm{NO}$ 
reakciói más molekulákkal a párosítatlan elektronból fakadnak, így igen jól reagál más szabadgyökökkel (Lancaster, 2015), de más molekulákkal is képes reakcióra.

A NO keletkezése állati rendszerekben fơként argininfüggő NO-szintáz (NOS) izoformákkal történik, mely argininből NADPH jelenlétében képes a citrullin és a NO szintézisére (Nappi és mtsai., 2000). Ezzel ellentétben a magasabbrendü növényeknél több különböző útvonalat különböztethetünk meg. Az állatihoz hasonló NOS enzim aktivitás jelenléte növényekben kérdéses. Az enzimaktivitást Corpas és mtsai. (2009) kimutatták, de a genomban mindmáig nem találták meg a hozzá illő proteint (Hancock és Neill, 2019). Habár NOS-szerü enzimet már felfedeztek algákban (Foresi és mtsai., 2010; Correa-Aragunde és mtsai., 2018), a magasabbrendü növényekben valószínüsíthetően inkább proteinek együttmüködéséből eredeztethető az arginin-függő NO termelés (Corpas és Barroso, 2017). A poliaminok mint redukált $\mathrm{N}$ vegyületek oxidatív lebontása is eredményezhet NO-képződést, ennek pontos mechanizmusa azonban még nem ismert (Wimalasekera és mtsai., 2011). Az enzimatikus útvonalak közül a reduktív folyamatok a növényi nitrogén asszimilációhoz kötöttek (Sanz-Luque és mtsai., 2013). A nitrát-reduktáz (NR) katalizálja a nitrit NO-vá alakítását, bár ennek aktivitása a nitrát redukcióhoz képest csupán 1\% körüli (Rockel és mtsai., 2002). A NR indirekt szereppel is rendelkezik az NO keletkezésében, mivel képes NAD(P)H-ról elektronok átvitelére egy NOformáló nitrit-reduktáz (NOFNiR) enzimre. Ez az enzim nitritet alakít át NO-vá, de a szerepét magasabbrendü növényekben még vizsgálni kell (Chamizo-Ampudia és mtsai., 2016). A gyökérben a specifikus nitrit:NO reduktáz (NiNOR) enzim katalizálja az NO keletkezését nitritböl (Stöhr és mtsai., 2001). A nem enzimatikus útvonalak speciális körülmények között jöhetnek létre. A karotinoidok képesek in vitro nitrogén-dioxid $\left(\mathrm{NO}_{2}\right)$ redukciójára fény hatására, mely NO felszabadulással járt (Cooney és mtsai., 1994). A nitrifikációs és denitrifikációs ciklusok közben az dinitrogén-oxid $\left(\mathrm{N}_{2} \mathrm{O}\right)$ is oxidálódhat NO-t eredményezve. A nitrit kémiai redukciója savas kémhatású környezetben is leírt folyamat (Bethke és mtsai., 2004), de ez lejátszódhat redukálószer nélkül is (Stöhr és Ullrich, 2002).

Valamennyi jelmolekulánál teljesítendő követelmény, hogy a szintje szabályozott legyen, és szükség esetén lebontó folyamatok aktiválódjanak. A NO lebontási folyamatai magukba foglalják az oxigénnel történő reakciót, mely eredményeképp nitrit és nitrát keletkezik. Különböző ROF-k szintén csökkentik a NO mennyiségét, mint például a $\mathrm{O}_{2}-\mathrm{s}$ a reakció során 
ONOO- $^{-}$keletkezik. Az NO szint csökkenésében szerepet játszhat a húgysav is (Alamillo és Garcia-Olmedo, 2001). Az NO képes reakcióba lépni a növényekben található nem szimbiotikus hemoglobinokkal, mely során nitrát keletkezik (Hebelstrup és mtsai., 2006). Az irodalom alapján ez a reakció főleg anoxia és hipoxia során játszik fontos szerepet (Dordas 2003; 2004; Hebelstrup és mtsai., 2006). Az összetett enzimatikus reakciók közül az S-nitrozoglutation- (GSNO) rendszert érdemes megemlíteni, mely egy mobilis NO raktár, valamint közvetíti az egyik biokémiai jelátviteli folyamatot (Corpas és mtsai., 2013).

A növényi sejtekben a NO nem rendelkezik specifikus receptorral, így a jeltovábbításért más folyamatok felelősek. Az RNF közvetlen reakciói makromolekulákkal poszttranszlációs módosításokat eredményeznek, melyek háromféle folyamatra oszthatóak fel: a fém-nitroziláció, az $S$-nitroziláció és a nitráció. A makromolekula-nitráció a nitro-oxidatív stressz egyik legáltalánosabb folyamata, így ennek tárgyalása a következő fejezetrészben történik meg. A protein $S$-nitroziláció során a GSNO specifikus cisztein aminosavak tiol oldalláncaira -NO csoportot kapcsol. A reakció reverzibilis és széleskörüen elterjed a magasabbrendű növényekben, így a nitrozatív jelátvitel egyik kulcsreakciójáról beszélhetünk. Az érintett proteinek kimutatása folyamatosan zajlik, de elmondható, hogy mind fiziológiás, mind stressszhelyzetben jelentős folyamatról van szó (Lindenmayr és mtsai., 2005; Fares és mtsai., 2011; Puyaubert és mtsai., 2014; Sehrawat és Deswal, 2014; Gietler és mtsai., 2016; Kolbert és mtsai., 2019c). Hu és mtsai., (2015) 926 S-nitrozilációra érzékeny proteint mutattak ki lúdfüben, melyek 28.96\%-a a metabolizmushoz volt köthető. A kimutatott proteinek között vannak a redox homeosztázisban fontos szerepüek, mint például a CAT 1-3, APX 1, DHAR 1 és 2, SOD 2. Érdemes továbbá megemlíteni, hogy a reakció reverzibilitása miatt az $S$-nitrozilációt elszenvedett proteinek képesek NO felszabadítására (Begara-Morales és mtsai., 2018). A NO másik jeltovábbító reakciója a fém nitroziláció, mely során az NO molekula metalloproteinek átmeneti fémjével hoz létre komplexet. A növényeknél ez a jelátvitelt módosító mechanizmus még nem bizonyított, de állati rendszerekben hemproteinekben, mint a guanilát-cikláz vagy citokróm-c-oxidáz már bizonyított a szerepe (Henry and Guissani 1999, Zhang et al. 2016). A növényi sejtre az NO két, általánosabb jelátviteli útvonalon keresztül is hat. Kimutatták az $\mathrm{NO}$ és $\mathrm{Ca}^{2+}$ jelátvitel kölcsönhatásait is. A $\mathrm{Ca}^{2+}$-szint növekedését indukálhatja az $\mathrm{NO}$, valamint a $\mathrm{Ca}^{2+}$ is képes elősegíteni az NO termelést (Jeandroz és mtsai., 2013). Leírták továbbá az NO és a MAPK 
kaszkád kapcsolatát uborkában (Pagnussat és mtsai., 2004), ahol az NO kezelés aktiválta az MAPK kaszkádot.

Az NO keletkezése, kioltása és jelátviteli kapcsolatai összefoglalásra kerültek a 5. ábrán.

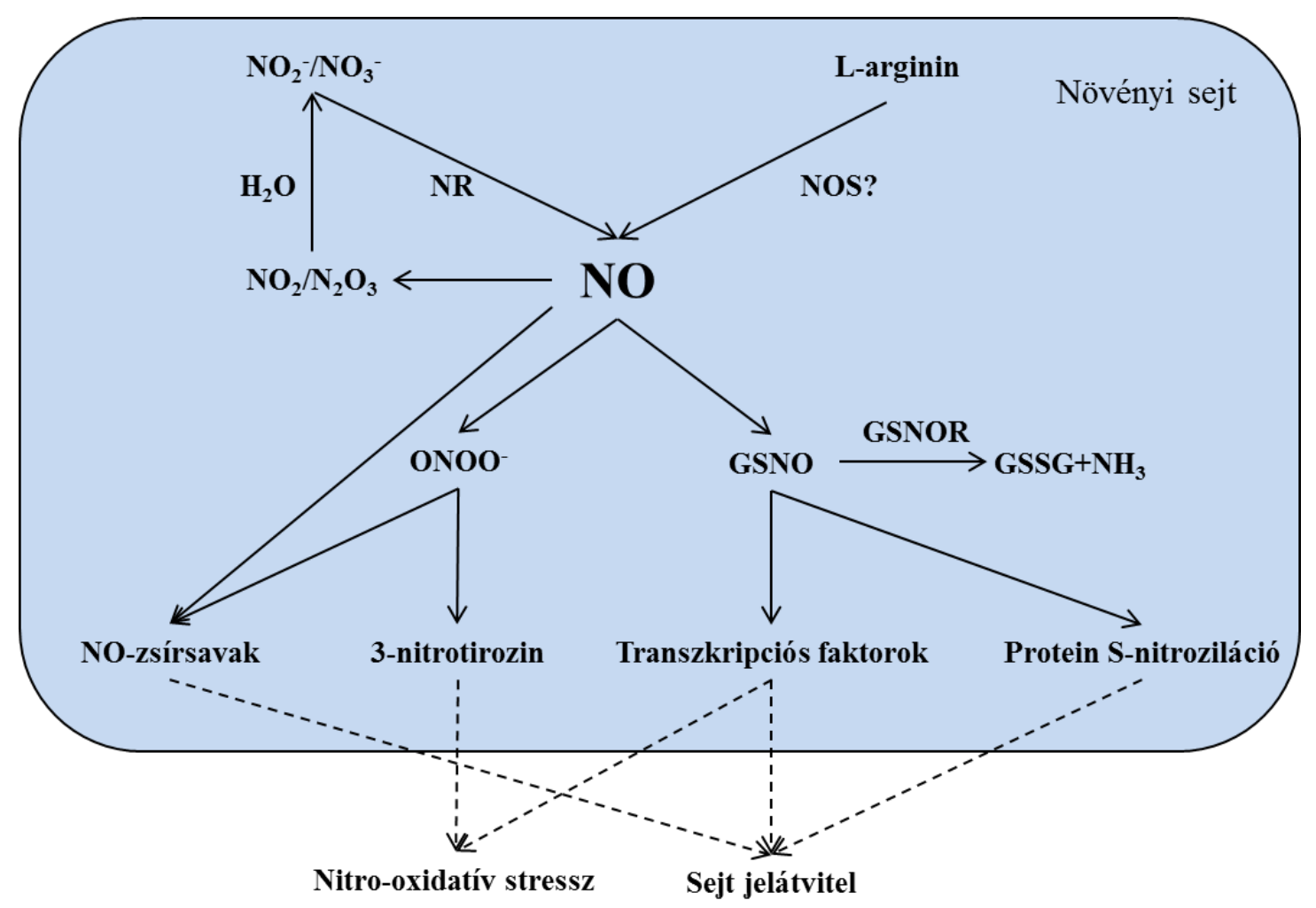

5. ábra Az NO metabolizmus sematikus összefoglalása a növényi sejtekben Corpas és mtsai., 2018 alapján. Rövidítések: nitrit $\left(\mathrm{NO}_{2}{ }^{-}\right)$, nitrát $\left(\mathrm{NO}_{3}{ }^{-}\right)$, nitrát reduktáz $(\mathrm{NR})$, nitrogén-dioxid $\left(\mathrm{NO}_{2}\right)$, dinitrogén-trioxid $\left(\mathrm{N}_{2} \mathrm{O}_{3}\right)$, Larginin dependens nitrogén-monoxid szintáz szerủ aktivitás (NOS?), nitrogén-monoxid (NO), peroxinitrit ( $\left.\mathrm{ONOO}^{-}\right)$, S-nitrozoglutation (GSNO), S-nitrozoglutation reduktáz (GSNOR), oxidált glutation (GSSG).

Az RNF és a szelén többlet kapcsolatát jelenleg is aktívan vizsgálják, így az irodalom gyérebb, mint az oxidatív stresszel kapcsolatban. Kutatócsoportunk az elsők között kezdte meg a RNF szerepének vizsgálatát szelén terhelt növényekben. Lehotai és mtsai. (2012) munkájában a NO szint lúdfü csíranövényekben a rövidtávú szelén kezelés hatására egy koncentrációfüggő csökkenést mutatott, míg hosszabb távon a toxikus szelén koncentrációk megnövelték a NO szintet. Az NR mutáns nialnia2 vonal érzékenynek bizonyult a szelénnel szemben, míg a GSNO túltermelö gsnorl-3 toleráns volt a vad-típushoz képest. Mivel mindkét vonalban csökkent 
endogén NO szint van, így feltételezhető, hogy az NO/GSNO arány játszhat szerepet a toleranciában. Más kísérletekben a lúdfü gyökerek NO tartalma szelén hatására jelentősen csökkent (Lehotai és mtsai., 2016a), de a szelén itt a citokinin jelátvitelen keresztül csökkentette az NO-szintet. Brassica rapa gyökerekben (Chen és mtsai., 2014) egy szeléntoxicitással összefüggő NO-akkumulációt írtak le, mely oxidatív robbanást is eredményezett. Az endogén NO szint emelése nátrium nitroprusszid (SNP) donorral rizsben foszfát és szulfát transzporterek túltermelését eredményezte, mely megemelte a növények SeCys és SeMet szintjét (Xiao és mtsai., 2017). Így feltételezhető, hogy a szelén képes hatni az NO metabolizmusára, az NO pedig hat a szelén felvételére, mely egy összetett jelátviteli kapcsolatról tanúskodik a Se és a NO között.

\section{7. A nitro-oxidatív stressz}

A nitro-oxidatív stressz a növénybiológiai szakirodalomban egy újabb kifejezés, melyet Corpas és Barroso (2013) javasolt először. A ROF és RNF metabolizmus nagymértékben kihat egymásra, és általánosságban a legtöbb stresszfolyamat mindkét jelátvitelt módosítja. A különböző stresszfolyamatok hatására egyszerre létrejövő nitrozatív és oxidatív stresszt számos abiotikus stresszornál leírták, mint a só (Valderrama és mtsai., 2007), szárazság (Signorelli és mtsai, 2013), szelén (Lehotai és mtsai, 2016b), cink (Feigl és mtsai., 2015), alacsony hőmérséklet (Airaki és mtsai., 2012). Néhány kísérlet során a hatáshoz a ROF és NO megfelelő egyensúlyban váltottak ki csupán hatást: szója sejtszuszpenzióban nagymértékű NO-termelődés mellett oxidatív robbanás nélkül a sejthalál elmaradt (Delledonne és mtsai., 2001).

A két molekulacsoport kölcsönhatását legjobban az GSNO-n keresztül lehet szemléltetni. Az GSNO egy mobilis NO raktárként viselkedik a növényekben, melyet az NO és GSH közvetett reakciója hoz létre. A reakció folyamán vagy $\mathrm{N}_{2} \mathrm{O}_{3}$ és GSH vagy glutionilgyök és NO reagál (Keszler és mtsai., 2010; Broniowska és mtsai., 2013). A kutatások szerint a GSNO szint összemérhető az oxidált glutation mennyiségével (Airaki és mtsai., 2011), mely így szintén kihat a sejt redox homeosztázisára. A bontásáért a GSNO-reduktáz (GSNOR) felelős, mely NADPHfüggő úton a GSNO-t GSSG-re és ammóniára bontja (Jahnová és mtsai., 2019). Ez a reakció közvetlenül befolyásolja az NO szintet és a GSH/GSSG arányt, így a sejt redox homeosztázisát 
(Chaki és mtsai., 2009; Yun és mtsai., 2011; Espunya és mtsai., 2012). Az enzim egy gén (At5g43940) által kódolt lúdfüben, és kimutatták a citoplazmában és a sejtmagban (Xu és mtsai., 2013). Bablevelekben jelen van a citoplazmában, mitokondriumban, kloroplasztiszban és peroxiszómákban is (Barroso és mtsai., 2013). Felépítése szerint a proteinben sok cisztein található, melyekhez két $\mathrm{Zn}^{2+}$ atom kapcsolódik (Lindermayr, 2018). Az enzim a katalitikus helyén lévő cisztein aminosavakkal képes reakcióba lépni a $\mathrm{H}_{2} \mathrm{O}_{2}$-dal, mely inaktiválódással és $\mathrm{Zn}^{2+}$ felszabadítással jár (Kovács és mtsai., 2016). Megfigyelték továbbá a GSNOR $S$ nitrozilációját, mely szintén inaktiválta az enzimet (Guerra és mtsai., 2016). A GSNO/GSNOR rendszer valószínúleg a kulcsa a ROF és RNF metabolizmus kapcsolatának, s a szoros kölcsönhatásuk részben ezen a molekulán keresztül valósul meg.

A másik jelentős kapcsolat a molekulacsaládok között a ONOO- képződése, ami az NO és $\mathrm{O}_{2}{ }^{-}$reakciójának az eredménye, és képes más molekulák kovalens módosítására. Az általa katalizált reakció a nitráció, mely során különböző makromolekula-oldalláncokat nitro $\left(-\mathrm{NO}_{2}\right)$ csoporttal lát el. Ez létrejöhet lipidekben, nukleinsavakban, de a növényekben leginkább vizsgált a fehérjenitráció. A fehérjék nitrációja több aminosavon jöhet létre, ilyen a tirozin, metionin, cisztein és triptofán (Kolbert és mtsai., 2017). A legnagyobb fiziológiai jelentőségü ezek közül a proteintirozin-nitráció (PTN), melyet régóta a nitrozatív jelátvitel markereként alkalmaznak (Corpas és mtsai., 2007). A PTN-t először Ichiropoulos és mtsai. (1992) mutatták ki in vivo. A makromolekula-módosítás biokémiailag két lépésre osztható: az első lépésben a Tyr ortho állású szénatomján oxidáció történik, és a molekula tirozilgyökké válik. Ez a tirozilgyök a peroxinitritből származó nitráló ágenssel egy addíciós reakción keresztül 3-nitrotirozint alkot (Kolbert és mtsai., 2017)(6. ábra). A módosítás a fehérjén megváltoztathatja annak térbeli konformációját, s legtöbbször inaktiválja az érintett fehérjét. Az APX és MDHAR enzimekről bizonyított, hogy a nitráció inaktiválja öket, míg a GR aktivitására a PTN-nak nem volt számottevő hatása (Begara-Morales és mtsai., 2014,2015). 


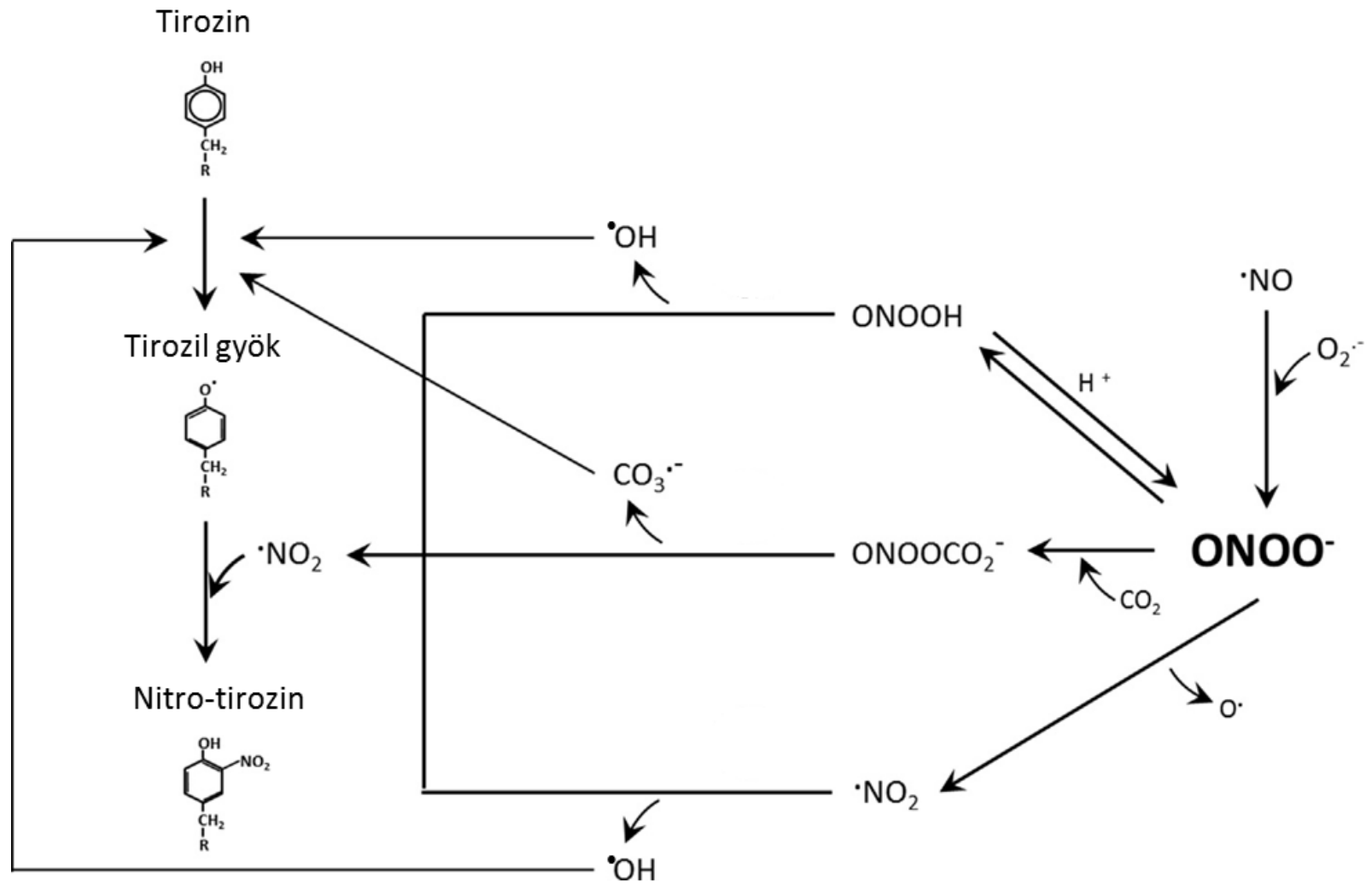

6. ábra A proteintirozin-nitráció biokémiai mechanizmusa Kolbert és mtsai. (2017) alapján. A tirozil-gyök kialakításában direkt oxidánsok vesznek részt, míg a végtermék kialakítása egy addíciós reakción keresztül történik. Rövidítések: hidroxilgyök $\left({ }^{\bullet} \mathrm{OH}\right)$, peroxinitrites sav $(\mathrm{ONOOH})$, karbonát gyökanion $\left(\mathrm{CO}_{3}{ }^{-}\right)$, nitrogén-monoxid (NO), nitrogén-dioxid ( $\left.\mathrm{NO}_{2}\right)$, szuperoxid gyökanion $\left(\mathrm{O}_{2}{ }^{-}\right)$, peroxinitrit $\left(\mathrm{ONOO}^{-}\right)$, nitrozo-peroxikarbonsav $\left(\mathrm{ONOOCO}_{2}^{-}\right)$.

A PTN fiziológiás körülmények között is lejátszódik a növényekben (Kolbert és mtsai., 2017), de a nitrációs mintázat megváltozik különböző abiotikus és biotikus stresszek hatására, mint a só (Valderrama és mtsai., 2007), patogének (Cecconi és mtsai., 2009), szárazság (Signorelli és mtsai., 2013), $\mathrm{Zn}^{2+}$ (Feigl és mtsai., 2015), szelén (Lehotai és mtsai., 2016b). Az így módosuló aktív fehérje-pool számottevő toxicitást jelenthet a növények számára. Az irodalomban már több tanulmányban is azonosítottak a nitráció hatására módosuló proteineket (Castillo és mtsai., 2015; Szuba és mtsai., 2015; Takahasi és mtsai., 2015; Begara-morales és mtsai., 2019; Signorelli és mtsai., 2019), de a vizsgálatok még jelen pillanatban is folyamatban vannak. Fontos megemlíteni, hogy jelentős anyagcsereutak fehérjéi, mint a szén homeosztázisban szerepet játszó ferredoxin-NADPH reduktáz és szénsav andhidráz is inaktiválódik nitráció hatására (Chaki és mtsai., 2011, 2013). A nitráció az inaktiváláson kívül megzavarhatja a fehérjék 
foszforilációját is, így a két poszttranszlációs módosítás közötti kompetíciót sem szabad kizárni (Souza és mtsai., 2008).

A nitrált fehérjék hosszútávú sorsa a növényekben néhány folyamatot foglal magába. A nitro csoport redukálódhat amino-tirozin gyökké, de ezt még nem sikerült azonosítani növényekben. Állati rendszerekben beszámoltak már a denitrációról, de ezt növényekben szintén nem sikerült azonosítani. A legáltalánosabb és növényekben is kimutatott a nitrált proteinek poliubikvitinációja és proteoszómális degradációja (Castillo és mtsai., 2015).

A peroxinitrit és nukleotidok reakciója két terméket eredményezhet a 8-oxoguanint és a 8nitroguanint (Sodum és Fiala, 2001; Jena és Mishra, 2007). A 8-nitroguanin megjelenését a RNS és mRNS-ban dokumentálták már Phytophtora infestans fertőzött burgonyában (Izbianska és mtsai., 2018). A feldúsulása az mRNS poolban tranziens volt a programozott sejthalál kezdetekor, így feltételezhető, hogy a biotikus stressz során müködő jelátvitelben volt szerepe. Alma csíranövényekben szintén detektálható volt az RNS nitráció növekedése a nyugalmi állapot elhagyásakor (Andryka-Dudek és mtsai., 2019). A folyamat teljes megértésétől még messze vagyunk, de a kutatások alapján valószínüsíthető, hogy a nukleinsav nitrációnak fontos szerepe van a sejt jelátvitelének finomhangolásában.

A fentieken kívül új kísérletek kimutatták a növényekben a nitrált zsírsavakat is. A lipidnitráció folyamán a zsírsav-oldalláncokhoz kapcsolódik a nitrocsoport. Ezidáig lúdfüben Mata-Pérez és mtsai. (2016a) nitro-linolénsavat, míg repce csíranövényekben Vollár és mtsai. (2020) nitro-olajsavat mutattak ki. Érdemes megemlíteni, hogy mindkét molekula képes NO felszabadításra (Mata-Pérez és mtsai., 2016b; Vollár és mtsai., 2020), de a pontos hatásuk még nem ismert. 


\section{Célkitüzés}

A fentebb leírtak alapján a korábbi kutatási eredmények bebizonyították, hogy a szelén terhelés és a nitro-oxidatív jelátvitel egymással kapcsolt folyamatok. A kutatás kezdetekor viszont nem volt még ismert a nitro-oxidatív stressz és szelén tolerancia kapcsolatának háttere és mértéke, valamint a reaktív nitrogénformák metabolizmusának változásai szelén stressz esetén. Ebből adódóan munkám során a szelén terhelés háttérfolyamatait vizsgáltam több, egymástól különböző kísérleti elrendezésben. A kutatómunka során megvizsgáltam a különböző szelénformák hatására az eltérő szeléntoleranciájú növényekben kialakuló toxicitás háttérfolyamatait. Megvizsgáltam a biomasszaprodukció változásait, a kialakuló nitro-oxidatív jelátvitel különbségeit és a növényfajok által alkalmazott toleranciamechanizmusokat is. Kísérleti rendszereimben a modellnövény lúdfüvet (Arabidopsis thaliana), a fitoremediációs és mezőgazdasági szempontból jelentős indiai mustárt (Brassica juncea), a gyógyászatban használt kínai csüdfüvet (Astragalus membranaceus) és a szelén hiperakkumuláló Astragalus bisulcatus-t alkalmaztam.

Kísérleteimmel a következő kérdésekre kívántam fényt deríteni:

1. A növények szelénfelvétele milyen mértékü, milyen a transzlokáció hatékonysága a szervek között a különböző kísérleti rendszerekben, valamint milyen mértékü akkumuláció jöhet létre egyes növényfajokban?

2. A különböző koncentrációjú szelénterhelés hogyan hat a növények növekedésére és biomassza-produkciójára?

3. Milyen mértékben képesek a vizsgált növényfajok türni a szeléntöbblet káros hatásait, s ehhez milyen toleranciamechanizmusokat alkalmaznak?

4. A szelénformák alkalmazott koncentrációi hogyan változtatják meg a növények ROF- és RNF-metabolizmusát, kialakul-e oxidatív robbanás, nitrozatív robbanás és nitro-oxidatív stressz?

5. Milyen összefüggést lehet feltételezni a nitro-oxidatív stressz mértéke és a szeléntolerancia/-érzékenység között? 


\section{Anyagok és módszerek}

\section{1. Növényi anyag és nevelési körülmények a különböző rendszerekben}

\section{1.1. Különböző szelénformákat összehasonlító kísérletek}

Az első kísérleti rendszerben a nehézfémek iránt toleráns indiai mustárt (Brassica juncea L. Czern. cv. Negro Caballo) vizsgáltuk. A magok felszínét 5 (v/v) \%-os nátrium-hipoklorit oldattal fertötlenítettük, majd a növények perlittel töltött Eppendorf csövek felszínére kerültek. A csövek a Hoagland tápoldat felszínén lebegtek, melynek összetétele: $5 \mathrm{mM} \mathrm{Ca}\left(\mathrm{NO}_{3}\right)_{2}, 5 \mathrm{mM}$ $\mathrm{KNO}_{3}, 2 \mathrm{mM} \mathrm{MgSO}_{4}, 1 \mathrm{mM} \mathrm{KH} \mathrm{PO}_{4}, 0,01 \mathrm{mM}$ Fe-EDTA, $10 \mu \mathrm{M} \mathrm{H}_{3} \mathrm{BO}_{3}, 1 \mu \mathrm{M} \mathrm{MnSO}_{4}, 5 \mu \mathrm{M}$ $\mathrm{ZnSO}_{4}, 0,5 \mu \mathrm{M} \mathrm{CuSO}_{4}, 0,1 \mu \mathrm{M}\left(\mathrm{NH}_{4}\right)_{6} \mathrm{Mo}_{7} \mathrm{O}_{24}$ és $10 \mu \mathrm{M} \mathrm{AlCl}_{3}$. A növények hidropónikusan egy 9 napos előnevelési periódussal rendelkeztek, majd átkerültek a levegőztetett kezelőoldat felszínére. A növények szelénkezelése a tápoldaton keresztül történt, mely 0 (kontroll), 20, 50 vagy $100 \mu \mathrm{M}$ nátrium-szelenitet $\left(\mathrm{Na}_{2} \mathrm{SeO}_{3}\right)$ vagy nátrium-szelenátot $\left(\mathrm{Na}_{2} \mathrm{SeO}_{4}\right)$ tartalmazott. $\mathrm{A}$ mintavétel minden kezelés esetében két hét múlva történt. A növények ellenőrzött körülmények között nevelkedtek: $150 \mu \mathrm{mol} \mathrm{m}{ }^{-2} \mathrm{~s}^{-1}$ fényintenzitás, 12 órás nappali és 12 órás sötét periódus, 55$60 \%$ páratartalom, $25 \pm 2{ }^{\circ} \mathrm{C}$ hömérséklet (7. ábra a).

\section{1.2. Különböző szelénérzékenységü növényfajok összehasonlítása}

\section{1.2.1. Keresztesvirágúak családjában}

A keresztesvirágúak családjába számos mezőgazdaságilag és tudományosan is fontos növény tartozik. A kísérleti rendszerben a szelénterhelés hatását vizsgáltuk a nehézfémtoleráns indiai mustáron (Brassica juncea L. Czern, cv. Negro Caballo) és a növénybiológia legfontosabb modellnövényén, a lúdfün (Arabidopsis thaliana L. Heynh, Columbia-0). A lúdfümagokat ültetés elött sterileztük, majd 0,7 (w/v) \% agart tartalmazó, feles erösségü Murashige-Skoog táptalajt tartalmazó Eppendorf csövek felszínére kerültek, melyek a tápoldaton lebegtek. Kísérleteinkben az előzőekhez hasonlóan hidropónikus rendszerben neveltük a növényeket. Az indiai mustár 9 napos előnevelési periódus után került kezelésre, míg a lúdfünek több idő kellett, hogy elérje a hasonló biomassza méretet, így itt az elönevelés 21 napig folyt. Mindkét növényfaj egy hét kezelési periódussal rendelkezett, a kezelés jelen esetben 0 (kontroll), 20, 50 vagy $100 \mu \mathrm{M}$ 
nátrium-szelenittel történt $\left(\mathrm{Na}_{2} \mathrm{SeO}_{3}\right)$. A növények állandó tápoldat-levegőztetés mellett nevelkedtek a mintavétel napjáig, a fent leírt ellenőrzött körülmények között (7. ábra b).

\section{1.2.2. $\underline{\text { Csüdfüvek családjában }}$}

A csüdfüfélék családjában számos különleges szelénmetabolizmussal bíró növényfajjal találkozhatunk. Szeretném kiemelni ezek közül a kísérleteinkhez használt szelénérzékeny Astragalus membranaceus L. Fisch, Bunge és a szelén-hiperakkumuláló Astragalus bisulcatus L. Hook, A. Gray fajokat. A magok felszíne 20 (v/v) \%-os nátrium-hipoklorit oldatban lett sterilezve, melyet négyszeri steril desztillált vizes öblítés követett. A magok felszíne steril fémrácsokon került szárításra, majd P400-as dörzspapírral a felső maghéj egy része eltávolításra került a csírázás lehetővé tételéhez. A magok ezután $0,8(\mathrm{w} / \mathrm{v}) \%$ agar tartalmú feles erősségü Murashige-Skoog táptalajra kerültek $12 \times 12 \mathrm{~cm}$ oldalú, szögletes, müanyag Petri-csészékben, melyet a következő kezelésekkel láttunk el: 0 (kontroll), 50 vagy $100 \mu \mathrm{M}$ nátrium-szelenát $\left(\mathrm{Na}_{2} \mathrm{SeO}_{4}\right)$. Mindkét növényfaj két hétig nevelkedett a fent leírt, ellenörzött körülmények között (7. ábra c).
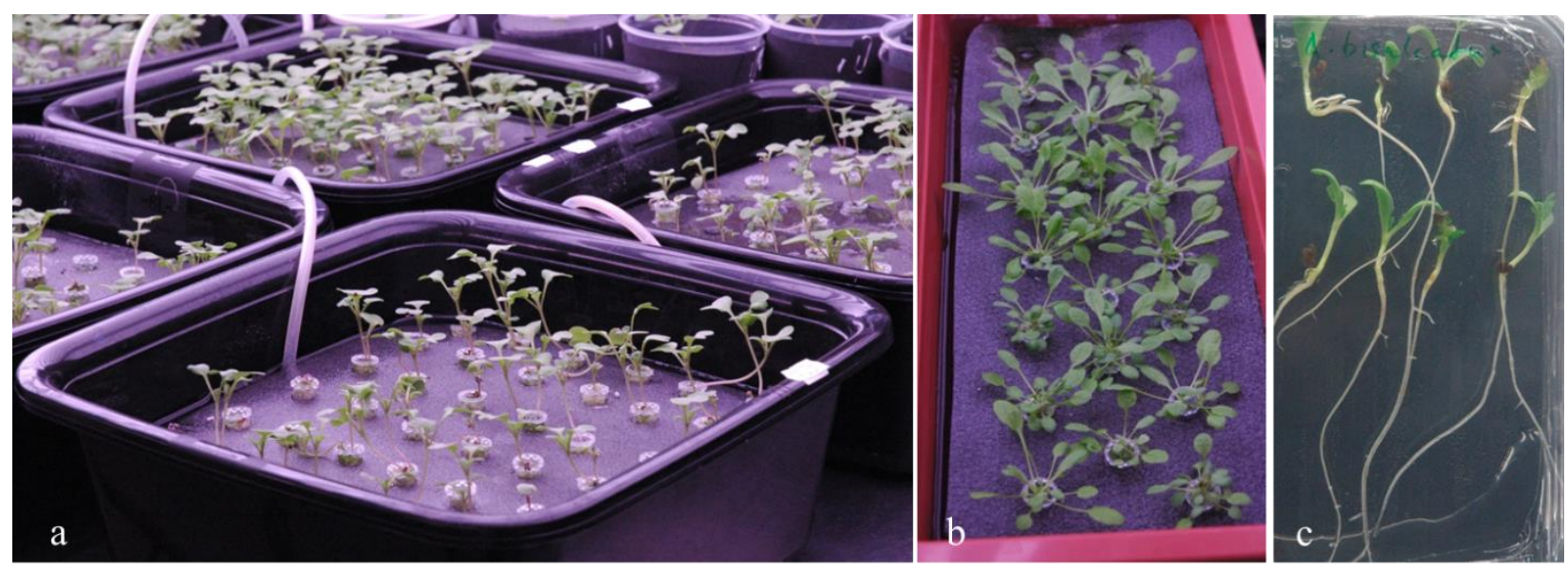

7. ábra A növénynevelés körülményei különböző kísérleti rendszereinkben. Indiai mustár (Brassica juncea) növények a hidropónikus nevelésük közben (a). Arabidopsis thaliana növények a 21 napos elönevelési periódusuk végén (b). Astragalus bisulcatus növények kontroll táptalajon növekedve a mintavétel napján (c).

\section{2. Csírázás, biomassza-produkció és sztómamüködés vizsgálata}

A csüdfüvek csírázási százalékának megállapításához minden Petri-csészében összeszámoltuk a csírázott magok számát, majd elosztottuk az összes kiültetett mag számával. Az 
eredményt százalékban ábrázoltuk. (A kísérleti mintaszáma a harmadik kísérleti rendszerben $\mathrm{n}(\mathrm{III})=15$ volt, 3 biológiai ismétléssel).

A gyökér és szár friss tömegének megállapítása analitikai mérleggel történt minden esetben. A száraz tömeg meghatározásához a mérés előtt a minta $70{ }^{\circ} \mathrm{C}$-on száradt 72 órán keresztül, majd a mérés ezután történt ugyanazzal az analitikai mérleggel, mint a friss tömegnél. A növények biomassza produkcióját milligrammban ábrázoltuk $(\mathrm{n}(\mathrm{I}, \mathrm{III})=15, \mathrm{n}(\mathrm{II})=20,3$ ism. $)$.

A fögyökérhosszmérés minden alkalommal vonalzóval történt, a toleranciaindex kiszámításához pedig a következő képletet használtuk:

$$
\text { Tolerancia index }(\%)=\frac{\text { Kezelt fögyökérhossz }}{\text { Átlagos kontroll fögyökérhossz }} \times 100
$$

$(\mathrm{n}(\mathrm{I})=15, \mathrm{n}(\mathrm{II})=20, \mathrm{n}(\mathrm{III})=10,3$ ism. $)$

A látható oldalgyökérszám meghatározása mustár és lúdfü növényeknél a főgyökér teljes hosszában történt, ahol manuálisan megszámoltuk a látható oldalgyökereket. Az adatokat db/gyökér egységben fejeztük ki $(n(I)=15, n(I I)=20, n(I I I)=10,3$ ism.).

Növényiszövet-keresztmetszethez a gyökér vagy sziklevél darabokat 4 (w/v) \%-os paraformaldehid oldatban fixáltuk Barroso és mtsai. (2006) alapján. A minták mosása desztillált vízzel történt, majd 5 (w/v) \%-os bakteriológiai agarba lettek ágyazva, Zelko és mtsai. (2012) módszerét enyhén módosítva. A mintákból $100 \mu \mathrm{m}$ vastagságú metszetek vibratómmal (VT 1000S, Leica) készültek.

Vizsgáltuk továbbá csüdfü keresztmetszeteken a sztéle, kortex és maga a teljes gyökér szélességét is. A vizsgálatok fénymikroszkópos felvételeken történtek és minden esetben mikrométerben adtam meg az adatokat $(\mathrm{n}(\mathrm{III})=6,2$ ism. $)$.

Sztómák sürüségének és nyitottságának meghatározásához epidermisz nyúzatot készítettünk lúdfü és indiai mustár fonákjáról, melyet $10 \mathrm{mM}$ 2-(N-Morfolino)-etán-szulfonsav (MES)/ 50 mM kálium-klorid $\mathrm{KCl}(\mathrm{pH}$ 6,15) pufferrel tárgylemezre helyeztem. A növényi mintáról 10- és 40-szeres nagyítással mikroszkópos felvételeket készítettünk a további 
vizsgálatokhoz. A 10-es nagyítású képeken öt $200 \mu \mathrm{m}$ átmérőjű kört helyeztem el egyenlő távolságra, s ezekben számoltam meg a sztómákat. A sürüséget darab $/ \mathrm{mm}^{2}$ egységben fejeztem ki A 40-szeres nagyítású fotókon a sztómanyílás méretét vizsgáltam, s az eredményeket mikrométerben ábrázoltam ( $(\mathrm{II})=200,3$ ism.).

\section{3. Elemtartalom-analízis}

A gyökér- és hajtásmintákat a vizsgálat napján először lemostuk desztillált vízzel, amit 70 ${ }^{\circ} \mathrm{C}$-on történő 72 órás szárítás követett. A száraz növényi anyagból $100 \mathrm{mg}$-ot porítottunk és 65 (v/v) \%-os salétromsavval két órán át inkubáltunk. Az inkubációs idő után 30 (w/v) \%-os $\mathrm{H}_{2} \mathrm{O}_{2}$ oldattal kezeltük a mintát és $200{ }^{\circ} \mathrm{C}$-on $1600 \mathrm{~W}$-on 15 percig roncsolásra kerültek (Mars Xpress CEM zárt mikrohullámú roncsoló készülék). A roncsolás befejeztével a mintákat megfelelő térfogatra higítottuk ki desztillált vízzel, és induktív csatolt plazma tömegspektrometriával megállapításra került az elemtartalom. A Brassica és Arabidopsis minták a Szegedi Tudományegyetem Szervetlen és Analitikai Kémiai Tanszékén lettek vizsgálva (Agilent 7700

Series, Santa Clara, Egyesült Államok), míg az Astragalus minták a Növénybiológiai Tanszéken kerültek elemzésre (Thermo Scientific XSeries II, Asheville, USA) (n(I,II,III)=3, 2 ism.).

\section{4. Mikroszkópos vizsgálatok}

\section{4.1. Nem fluoreszcens mikroszkópos technikák}

A gyökerek pektintartalmát ruténium vörös festékkel mutattuk ki Durand és mtsai. (2009) nyomán. A gyökereket 0,1 (w/v) \%-os desztillált vízben készült festékoldatba helyeztük 15 percre, majd ezt egy mosási lépés követte. A tárgylemezekre szintén desztillált vízzel történt a kirakás, a vizsgálatot pedig fénymikroszkóppal végeztük(n(II)=20, 3 ism.).

A növényi sejtfalban található peroxidázok aktivitását $0,2(\mathrm{w} / \mathrm{v}) \%$-os pirogallol oldattal mutattuk ki. Az oldat $10 \mathrm{mM}$-os foszfát pufferben készült $(\mathrm{pH} 7,0)$ és tartalmazott $0,03 \%(\mathrm{w} / \mathrm{v})$ $\mathrm{H}_{2} \mathrm{O}_{2}$ is. 15 perc festési idő után barnás elszíneződés jelentkezett az enzimaktivitás hatására, melyet fénymikroszkóppal vizsgáltunk (Eleftheriou és mtsai., 2015) $(\mathrm{n}(\mathrm{II})=10,3$ ism.).

A lipidperoxidáció során keletkezett reaktív aldehideket Arasimowicz-Jelonek és mtsai. (2009) nyomán mutattuk ki. A gyökereket 20 percre Schiff-reagens oldatba helyeztük, majd ezt 
cseréltük le ismét 20 percre $0,5(\mathrm{v} / \mathrm{v}) \%$-os $\mathrm{K}_{2} \mathrm{~S}_{2} \mathrm{O}_{5}$ oldatra a lilásrózsaszín szín stabilizálása érdekében $(\mathrm{n}(\mathrm{II})=10,3$ ism.).

A növények sziklevelében a $\mathrm{O}_{2}{ }^{--}$detektálása nitro-kék-tetrazólium (NBT) festéssel történt. A sziklevelek $5 \mathrm{ml}$ NBT oldatban $(1 \mathrm{mg} / \mathrm{ml}, 10 \mathrm{mM}$ foszfát pufferben, $\mathrm{pH}$ 7,4) 30 percig lettek festve fényen, majd ezután $80(\mathrm{v} / \mathrm{v}) \%$-os etanolban 30 percig $70{ }^{\circ} \mathrm{C}$-on kivonásra kerültek a pigmentek, láthatóvá téve a lilás elszíneződést (n(III)=10, 2 ism.).

\section{4.2. Fluoreszcens mikroszkópos technikák}

A gyökérszövetek életképességét fluoreszcein-diacetát (FDA) fluorofórral mutattuk ki Lehotai és mtsai. (2011) alapján. A gyökércsúcsokat $10 \mu \mathrm{M}$-os festékoldatban (10/50 mM $\mathrm{MES} / \mathrm{KCl}$ puffer, $\mathrm{pH}$ 6,15) fél óráig inkubáltuk sötétben, szobahőmérsékleten, majd négyszeri mosás után tárgylemezre helyeztük és mikroszkóp alatt fotóztam $(\mathrm{n}(\mathrm{I}, \mathrm{III})=15, \mathrm{n}(\mathrm{II})=10,3$ ism.).

A növényi sejtfal kallóz tartalmának kimutatására anilinkék festékanyagot használtunk. A gyökércsúcsokat $0,1(\mathrm{w} / \mathrm{v})$ \%-os festékoldatba (desztillált vízben készítve, tartalmazott $1 \mathrm{M}$

glicint) inkubáltuk 5 percig szobahőmérsékleten (Cao és mtsai., 2011), majd egyszer mostam desztillált vízzel. A tárgylemezekre desztillált vízzel történt a kirakás, majd fluoreszcens mikroszkóppal vizsgáltuk a mintákat (n(II)=10, 3 ism.).

A csüdfügyökér-keresztmetszeteket egy csepp vízzel tárgylemezre helyeztünk, majd a vizet 0,5 (w/v) \%-os anilinkék oldatra cseréltük. A növényi metszeteket öt perc után mostuk desztillált vízzel. A metszeteket fluoreszcens mikroszkóppal vizsgáltunk a kallóztartalom detektálásához, valamint látható fényben is készültek képek, melyeken a sztéle és egyéb sejtsorok szélességét mértünk Arduini és mtsai. (1995) alapján (n(III)=6, 2 ism.).

A csüdfügyökér-szövetek lignin- és szuberinberakódását 0,01 (w/v) \% Auramin O festékkel (10 mM Tris- $\mathrm{HCl}$ pufferben készítve, $\mathrm{pH}$ 7,4) vizsgáltuk (Rahoui és mtsai., 2017). A metszetek a festékoldattal lettek kezelve 10 percig, majd a zöld fluoreszcenciát mikroszkóp alatt detektáltuk. $(\mathrm{n}(\mathrm{III})=6,3$ ism. $)$

A NO molekula jelölésére DAF-FM DA (4-amino-5-metilamino-2',7'-difluorofluoreszcein diacetát) oldatot használtunk $10 \mu \mathrm{M}$-os koncentrációban $10 \mathrm{mM}$-os Tris- $\mathrm{HCl}$ pufferben $(\mathrm{pH}$ 7,4) 
készítve (Kolbert és mtsai., 2012). A gyökércsúcsokat 30 percen át sötétben festettük az oldatban, majd kétszeri mosás után tárgylemezen vizsgáltuk őket $(\mathrm{n}(\mathrm{I}, \mathrm{II})=10,3$ ism.; $\mathrm{n}(\mathrm{III})=10,2$ ism.).

A $\mathrm{ONOO}^{-}$detektálására dihidrorodamin (DHR) 123 festéket alkalmaztunk. A gyökércsúcsokat $10 \mu \mathrm{M}$-os festékoldatban $(10 \mathrm{mM}$ Tris- $\mathrm{HCl}$ puffer, $\mathrm{pH}$ 7,4) inkubáltuk. A 30 perces inkubáció sötétben történt, ezt követően kétszeri mosás következett pufferrel, majd a mintát mikroszkóp alatt vizsgáltunk (Sarkar és mtsai., 2014) (n(I,II)=10, 3 ism.; $n(I I I)=10,2$ ism.).

A gyökerek $\mathrm{O}_{2}$-szintjének kimutatására dihidroetídium (DHE) fluorofórt használtunk Kolbert és mtsai. (2012) alapján. A gyökércsúcsokat 30 percre $10 \mu \mathrm{M}$-os festékoldatba merítettük, amelyet $10 \mathrm{mM}$-os Tris- $\mathrm{HCl}$ pufferben $(\mathrm{pH}$ 7,4) készítettünk. A festési lépés után kétszer mostuk pufferrel a mintát, majd tárgylemezen vizsgáltuk (n(I,II)=10, 3 ism.; $n(I I I)=10,2$ ism.).

A $\mathrm{H}_{2} \mathrm{O}_{2}$ jelölésére Amplex Red (10-acetil-3,7-dihidroxifenoxazin) reagenst használtunk (Lehotai és mtsai., 2012). A festékanyagot $50 \mu \mathrm{M}$-os koncentrációban oldottuk $50 \mathrm{mM}$-os nátrium foszfát pufferben ( $\mathrm{pH} 7,5)$, majd a gyökereket 30 percig festettük benne. Ezt egyszeri mosási lépés és mikroszkópos vizsgálat követte ( $\mathrm{n}(\mathrm{II})=10,3$ ism.; $\mathrm{n}(\mathrm{III})=10,2$ ism.).

A növényi gyökércsúcsi merisztéma glutationtartalmát mono-bromo-bimán (MBB) festékmolekulával határoztuk meg. A $100 \mu \mathrm{M}$-os, desztillált vízben készült festékoldat egy órán keresztül volt a növényi gyökereken, majd egyszeri desztillált vizes mosás után a gyökereket fluoreszcens mikroszkóp alatt fotóztuk (Lehotai és mtsai., 2016a) (n(I,II)=10, 3 ism.).

IV 4.3. Immunjelölési technikák

A fentiekben leírt növényi metszeteket használtuk a következő két immunjelöléshez is. A GSNO tartalmat Corpas és mtsai. (2008) módszerét követve mutattuk ki, kisebb módosításokkal. A metszeteket 1:2500 arányban higított patkányból származó GSNO elleni antitesttel (VWR Chemicals, Poole, Anglia) jelöltük egy éjszakán át. Az antitestet TBSA-BSAT pufferben (pH 7,2) higítottuk ki, mely tartalmazott: $5 \mathrm{mM}$ Tris, 0,9 (w/v) \% nátrium-klorid, 0,05 (w/v) \% nátrium-azid, 0,1 (w/v) \% borjú szérum albumin, 0,1 (v/v) \% Triton X-100. A metszeteket 3-szor mostuk TBSA-BSAT pufferben 5 percig mosási lépésenként, majd 1:1000 higítású nyúlból 
származó, patkány elleni fluoreszcein-izotiocianát kapcsolt antitesttel (Agrisera, Vännäs, Svédország) inkubáltuk egy órán keresztül. A minták ezután fluoreszcens mikroszkóp alatt lettek fotózva (n(III)=5-6, 2 ism.).

A proteintirozin-nitráció láthatóvá tételére szintén immunjelölést használtun Valderrama és mtsai. (2007) alapján. A metszeteket 3 napon keresztül $4{ }^{\circ} \mathrm{C}$-on inkubáltuk 1:300-as higítású, nyúlban termelt 3-nitrotirozin (Sigma-Aldrich, St. Louis, Amerikai Egyesült Államok) elleni antitesttel. Ezt háromszor öt perces mosási lépés követte TBSA-BSAT pufferben, mely után 1:1000 higítású kecskében termelt nyúl elleni FITC kapcsolt másodlagos antitest (Agrisera, Vännäs, Svédország) oldatot mértünk a metszetekre. A metszetek egy óra szobahőmérsékleten történt inkubáció után tárgylemezre kerültek, és mikroszkóp alatt vizsgáltuk őket (n(III)=5-6, 2 ism.).

\section{4.4. A festési technikák mikroszkópos háttere}

A gyökércsúcsok vizsgálata minden esetben $\sim 0,5 \mathrm{~cm}$ hosszú gyökérszegmenseken történt, amelyekből módszerenként legalább 10 került festésre. A mikroszkópos vizsgálatok minden esetben Zeiss Axiowert 200M inverz mikroszkóppal (Carl Zeiss, Jena, Németország) történtek, amihez egy digitális kamera csatlakozik (Axiocam HR, HQ CCD, Carl Zeiss, Jena, Németország). A mikroszkóp különböző szürőkombinációi különböző excitációs és emissziós tartománnyal rendelkeznek, így minden fluoreszcens molekulához a megfelelőt alkalmaztuk. A 49-es filterszett (excitáció: $365 \mathrm{~nm}$, emisszió: 445/50 nm) az anilinkék és MBB emisszió kimutatásra volt alkalmas. A filter 9 (excitációs hullámhossz tartománya: 450-490 nm, emissziós

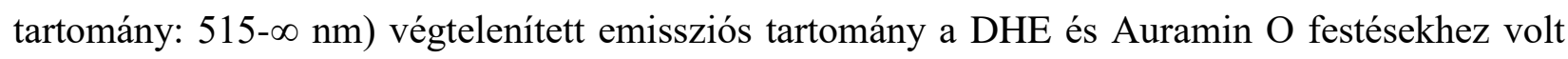
ideális. A filter 10 (excitációs hullámhossz tartománya: 450-490 nm, emissziós tartomány: 515 $565 \mathrm{~nm}$ ), mely a filter 9-hez képest végpontosított emissziós tartománnyal rendelkezik az FDA, DAF-FM DA, DHR 123 és FITC kapcsolt immunjelöléseknek felelt meg. A filter 20 HE (excitációs hullámhossz tartománya: 546/12 nm, emissziós tartomány: 607/80 nm) pedig a vörösen fluoreszkáló Amplex red reagenshez volt kiváló. Az gyökércsúcsok osztódási zónájáról készített fluoreszcens felvételeken az Axiovision Rel. 4.8 szoftverrel detektáltuk a pixelintenzitást. Minden mérésnél 100 mikrométer átméröjü körökben határoztuk meg a pixelintenzitást, mely egyenesen arányos a jelölt molekula mennyiségével. 
A festési módszereket az 1. táblázatban foglaltam össze.

\begin{tabular}{|c|c|c|c|c|}
\hline $\begin{array}{c}\text { Vizsgált } \\
\text { molekula }\end{array}$ & Festékanyag & Puffer & $\begin{array}{c}\text { Mikroszkópos } \\
\text { filter }\end{array}$ & $\begin{array}{c}\text { Irodalmi } \\
\text { hivatkozás }\end{array}$ \\
\hline Pektin & Ruténium vörös & Desztillált víz & fénymikroszkópia & $\begin{array}{l}\text { Durand és mtsai., } \\
2009\end{array}$ \\
\hline Sejtfali peroxidázok & Pirogallol & $\begin{array}{c}10 \mathrm{mM} \text { foszfát } \\
\text { puffer }\end{array}$ & fénymikroszkópia & $\begin{array}{l}\text { Eleftheriou és } \\
\text { mtsai., } 2015\end{array}$ \\
\hline Lipid peroxidáció & Schiff reagens & $\mathrm{K}_{2} \mathrm{~S}_{2} \mathrm{O}_{5}$ & fénymikroszkópia & $\begin{array}{c}\text { Arasimowicz- } \\
\text { Jelonek és mtsai., } \\
2009\end{array}$ \\
\hline Életképesség & FDA & $\begin{array}{l}10 / 50 \mathrm{mM} \\
\mathrm{MES} / \mathrm{KCl}\end{array}$ & Zeiss Filter 10 & $\begin{array}{l}\text { Lehotai és mtsai., } \\
\qquad 2011\end{array}$ \\
\hline Kallóz & Anilinkék & Desztillált víz & Zeiss Filter 49 & Cao és mtsai., 2011 \\
\hline Lignin és szuberin & Auramin $\mathrm{O}$ & $10 \mathrm{mM}$ Tris- $\mathrm{HCl}$ & Zeiss Filter 9 & $\begin{array}{c}\text { Rahoui és mtsai., } \\
2017\end{array}$ \\
\hline $\mathrm{NO}$ & DAF-FM DA & $10 \mathrm{mM}$ Tris- $\mathrm{HCl}$ & Zeiss Filter 10 & $\begin{array}{l}\text { Kolbert és mtsai., } \\
\qquad 2012\end{array}$ \\
\hline $\mathrm{ONOO}^{-}$ & DHR 123 & $10 \mathrm{mM}$ Tris- $\mathrm{HCl}$ & Zeiss Filter 10 & $\begin{array}{c}\text { Sarkar és mtsai., } \\
2014\end{array}$ \\
\hline $\mathrm{O}_{2}^{--}$ & DHE & $10 \mathrm{mM}$ Tris- $\mathrm{HCl}$ & Zeiss Filter 9 & $\begin{array}{l}\text { Kolbert és mtsai., } \\
2012\end{array}$ \\
\hline
\end{tabular}




\begin{tabular}{|c|c|c|c|c|}
\hline \multirow{2}{*}{$\mathrm{H}_{2} \mathrm{O}_{2}$} & Amplex Red & $\begin{array}{c}50 \mathrm{mM} \text { Na-foszfát } \\
\text { puffer }\end{array}$ & Zeiss Filter 20 & $\begin{array}{c}\text { Lehotai és mtsai., } \\
2012\end{array}$ \\
\hline Glutation & MBB & Desztillált víz & Zeiss Filter 49 & $\begin{array}{c}\text { Lehotai és mtsai., } \\
2016\end{array}$ \\
\hline GSNO & Antitest & TBSA-BSAT & Zeiss Filter 10 & $\begin{array}{c}\text { Corpas és mtsai., } \\
2008\end{array}$ \\
\hline 3-nitrotirozin & Antitest & TBSA-BSAT & Zeiss Filter 10 & Valderrama és \\
& & & & mtsai., 2007 \\
\hline
\end{tabular}

1. táblázat A munkám során használt különböző festési technikák összefoglaló bemutatása.

\section{5. Proteintirozin-nitráció vizsgálata western blot analízissel}

A növényi proteinkivonat készítéséhez $250 \mathrm{mg}$ gyökér- vagy hajtásminta lett homogenizálva $500 \mu$ extrakciós pufferrel $(50 \mathrm{mM}$ Tris- $\mathrm{HCl}$ puffer $\mathrm{pH}$ 7,6-7,8, mely tartalmazott: 0,1 mM EDTA, 0,1 (v/v) \% Triton X-100, 10 (v/v) \% glicerol), majd a homogenizátumot 9300 g-n 20 percig $4{ }^{\circ} \mathrm{C}$-on centrifugáltuk. A felülúszóhoz 1 (v/v) \% növényi proteázinhibitor-koktélt (Sigma-Aldrich, katalógus szám: P9599) mértünk, majd felhasználtuk a natív és denaturáló gélelektroforézishez. A minták fehérjetartalmát Bradford (1976) módszere alapján határoztuk meg borjú szérum albumint használva kontrollként.

A proteintirozin-nitráció vizsgálatához western blot analízist alkalmaztunk. $25 \mu \mathrm{g}$ fehérjét tartalmazó hajtás- vagy gyökérkivonatot 12 (w/v) \%-os denaturáló poliakrilamid gélelektroforézisnek vetettem alá. Az így szeparált fehérjéket az akrilamid gélből tank transzfer segítségével transzfereltük PVDF membránra (16 h, 25 mA). Az így kapott PVDF membránok először 5 (w/v) \%-os tejfehérje oldatban blokkolva lettek, mely TBST pufferben készült (20 mM Tris, $178 \mathrm{mM} \mathrm{NaCl}, 0,05 \%$ Triton $\mathrm{X}-100, \mathrm{pH} 7,8$ ), a nem specifikus antitest kötés elkerülése végett, majd 1:2000 arányban higított nyúl 3-nitrotirozin elleni antitesttel (Sigma-Aldrich, 
katalógus szám: N0409) jelöltük őket. Három mosási lépés után 1:10000 arányban higított kecske nyúl IgG elleni antitestet (Sigma-Aldrich, katalógus szám: A3687) alkalmaztunk, mely alkalikus foszfatázt hordozott detektáláshoz. A nitrált fehérjék láthatóvá tételére BCPIP/NBT reakciót használtunk, ahol az antitesttel jelölt fehérjéknél fekete színü formazán keletkezik. A reakció pozitív kontrolljaként nitrált borjú szérum albumint vittünk fel a gélre (Sigma-Aldrich, katalógus szám: N8159) (n(I,II,III)=3, 2 ism.).

Loading kontrollként a membránokat Coomassie R 250 festéssel vizsgáltuk Welinder és Ekblad (2011) alapján, kisebb módosításokkal. A membránokat kétszer mostuk TBST pufferben, majd festékoldatba $(0,1(\mathrm{w} / \mathrm{v}) \%$ Coomaisse R 250, $50(\mathrm{v} / \mathrm{v}) \%$ metanol) merítettük 1 percig. A membránok mosása $10(\mathrm{v} / \mathrm{v}) \%$ ecetsavat és $50(\mathrm{v} / \mathrm{v}) \%$ etanolt tartalmazó oldattal történt 10 percig.

A denaturáló és natív gélekben a fehérjék megfelelő futásának vizsgálatára ezüstfestést alkalmaztünk Blum és mtsai. (1987) módszerét használva, kisebb módosításokkal. A gélek egy éjszakán át fixálóban (10 (w/v) \% ecetsav, $50(\mathrm{v} / \mathrm{v}) \%$ metanol) voltak, majd három desztillált vizes mosás után szenzitizáló oldatba $(0,00216(\mathrm{w} / \mathrm{v}) \%$ nátrium-tioszulfát desztillált vízben oldva) kerültek. A következő lépés az ezüst oldat $(0,2$ (w/v) \% ezüst-nitrát, 0,075 (v/v) \% formaldehid) majd egy mosás után az előhívás (5 (w/v) \% nátrium-karbonát, 0,05 (v/v) \% formaldehid, 0,000048 (w/v) \% nátrium-tioszulfát) következett.

\section{6. Natív gélelektroforézishez kapcsolható módszerek}

A NADPH-oxidáz izoenzimek vizsgálata López-Huertas és mtsai. 1999-es módszere alapján történt, kisebb módosításokkal. A növényi fehérjekivonatot 10 (w/v) \%-os natív poliakrilamid gélelektroforézissel elválasztottuk, majd a gélt reakció pufferbe helyeztük (10 mM Tris-HCl, mely tartalmazott 0,2 mM NADPH és 0,2 NBT) 20 percre, sötétben. A NAPDH-oxidáz enzim aktivitása lila szín formájában detektálódott a gélen. A NADPH-oxidáz aktivitás specifitásának igazolására az enzimre specifikus gátlószert, difenilén-jodóniumot használtunk $(\mathrm{n}(\mathrm{III})=3,2$ ism. $)$.

A SOD enzim aktivitását és izoformáit a fentiekhez hasonlóan 10 (w/v) \%-os nem denaturáló, natív gélelektroforézis után határoztuk meg (Beauchamp and Fridovich, 1971). Az 
elválasztott géleket elöször kálium-foszfát pufferben kétszer mostuk (50 mM, pH 7,5) majd sötétben 20 percig 2,45 mM-os NBT oldatban inkubáltuk. Ezt az oldatot cseréltük egy foszfát pufferben elkészített $28 \mathrm{mM}$ TEMED és $2,92 \mu \mathrm{M}$ riboflavint tartalmazó oldalra, melyben 15 percet inkubálódtak. A gélek ismételt kétszeri mosása után fény hatására láthatóvá váltak a SOD enzimek. Az izoformák detektálására az első mosási lépések után a géleket gátlószerekkel kezeltem: a kálium-cianid csak a réz/cink SOD gátlására képes, míg a $\mathrm{H}_{2} \mathrm{O}_{2}$ a réz/cink, valamint a vas kofaktorral rendelkező SOD izoformákat is inaktiválja, így csupán a mangán SOD lesz detektálható. $(\mathrm{n}(\mathrm{III})=3,2$ ism.)

A GSNO-reduktáz enzim aktivitását Seymour és Lazarus 1989-es módszere nyomán határoztuk meg, kisebb módosításokkal. A növényi mintát 6 (w/v) \%-os Tris-borát-EDTA (8,9 mM Tris, 8,9 mM bórsav, 0,2 mM Na2EDTA, pH 8) géleken választottam el, majd 15 percre 100 mM-os nátrium-foszfát pufferben $(\mathrm{pH} 7,4)$ készített 2 mM-os NADH oldatba merítettük. Ezután 3 mM-os GSNO oldatot vittünk fel a gélekre, majd géldokumentációs rendszerrel (Image System Felix 1000/2000, Biostep, Burkhardtsdorf, Németország) detektáltuk a NADH autofluoreszcencia eltűnését az enzimaktivitás függvényében ( $(\mathrm{III})=3,2$ ism.).

\section{7. Spektrofotometriai vizsgálatok}

A Brassica levelek antociántartalmának vizsgálatához 25 mg növényi mintát 100 (v/v) \%os acetonnal eldörzsöltünk, majd $4{ }^{\circ} \mathrm{C}$-on inkubáltuk 24 órán keresztül. Az inkubáció után a mintát centrifugáltam 9300 g-n, $4{ }^{\circ} \mathrm{C}$-on 10 percig, majd a felülúszót leszívtuk róla. A maradék növényi anyagra $80(\mathrm{v} / \mathrm{v}) \%$-os acetont mértünk és ismét extraháltuk 24 órán keresztül. A fentiekhez hasonlóan ismét egy centrifugálási lépés következett, majd a felülúszót hozzáadtuk az elöző felülúszóhoz és fotométerrel meghatároztam a pigmentkivonat abszorpcióját 534, 634 és $661 \mathrm{~nm}$-en. Az antocianintartalmat a következő képlettel határoztuk meg és mg/ml-ben ábrázoltuk (n(II)=6, 2 ism.).

Antocianin $=0,0821 * \mathrm{~A}_{534}-0,00687 * \mathrm{~A}_{643}-0,002423^{*} \mathrm{~A}_{661}$

A SOD enzim aktivitásának fotometriás vizsgálatára Dhindsa és mtsai. (1981) által leírt módszert alkalmaztuk. A felhasznált enzimkivonathoz 250 mg növényi mintát dörzsöltünk el 1 $\mathrm{ml}$ extraháló pufferben $(50 \mathrm{mM}$ foszfát puffer $\mathrm{pH}$ 7,0,1 mM EDTA hozzáadásával) $10 \mathrm{mg}$ 
polivinil-polipirrolidonnal. A homogenizált növényi anyagot 9300 g-n $4{ }^{\circ} \mathrm{C}$-on 20 percig centrifugáltuk és a méréshez a felülúszót használtuk fel. A módszer alapjául szolgál, hogy a SOD enzim képes gátolni az NBT fotokémiai redukcióját formazánná. Az enzimaktivitást aktivitásegység/gramm friss tömegben ábrázoltuk, ahol egy egység az NBT fotokémiai redukciójának felét akadályozza meg $(\mathrm{n}(\mathrm{III})=3,3$ ism.).

\section{8. Statisztikai analízis}

Az eredmények statisztikai elemzése Microsoft Excel 2010, Systat Sigmaplot 12 és Statistica 9 programokkal történt. A szignifikancia megállapítására többek között Student-féle T próbát alkalmaztunk, ahol a statisztikailag jelentős eltéréseket * $\mathrm{P} \leq 0,05 ; * * \mathrm{P} \leq 0,01 ; * * * \mathrm{P} \leq$ 0,001 jelölésekkel mutattuk be. Az adatok elemzése történhetett ezen kívül Duncant teszttel $(\mathrm{P} \leq$ 0,05), Kruskal-Wallis ANOVA segítségével $(\mathrm{P} \leq 0,05)$ és Mann-Whitney U-teszttel történt $(* \mathrm{P} \leq 0,05, \quad * * \mathrm{P} \leq 0,01, * * * \mathrm{P} \leq 0,001)$. A grafikonokon az átlageredményeket ábrázoltuk a mintacsoportok standard hibájának ábrázolásával. 


\section{Eredmények}

\section{1. Különböző szelénformákat összehasonlító kísérletek}

A szelénstressz hatásának elemzéséhez elöször a felvételét kellett bizonyítani. ICP-MS műszerrel vizsgáltuk a $B$. juncea szervek szelénmennyiségét a különböző szelénformákkal történő kezelések hatására. A szelenátkezelés koncentráció-függő módon, jelentősen növelte minden kezelési koncentrációban a gyökér, valamint kimagaslóan a hajtás szeléntartalmát. Ezzel összehasonlítva, a szelenit szintén megnövelte a gyökér szeléntartalmát, de a hajtásba történő transzlokációja jóval gyengébb volt (8. ábra).

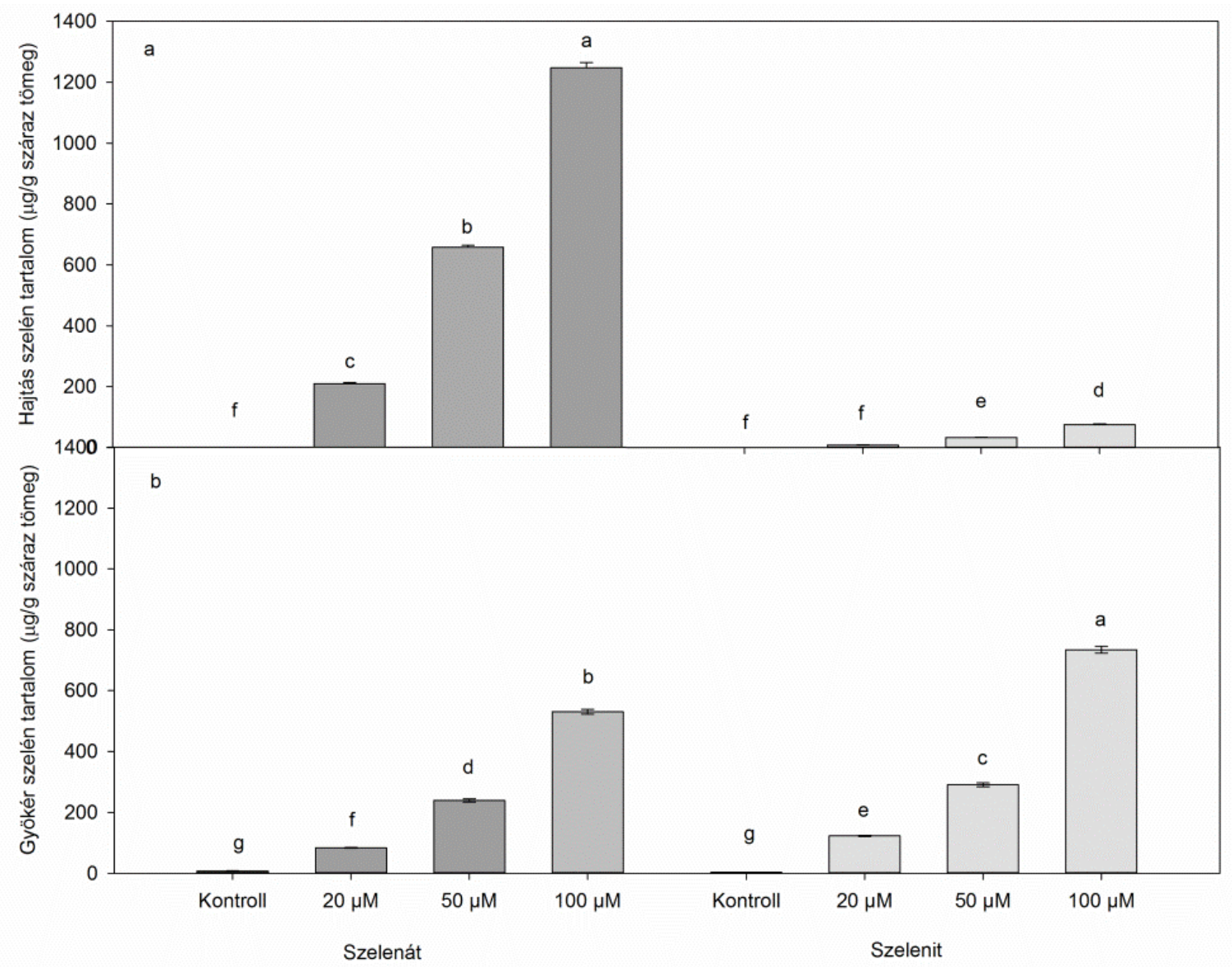

8. ábra Szelénkoncentrációk különböző szelénformákkal kezelt Brassica juncea szervekben 14 nap kezelési periódus után. A hajtás (a) és gyökér (b) szeléntartalma $\mu \mathrm{g} / \mathrm{g}$ száraz tömegben ábrázolva. A különböző betűk szignifikánsan különböző adatsorokat jelentenek a Duncan teszt alapján ( $\mathrm{n}=3, \mathrm{P} \leq 0,05)$. 
A felvett szelénformák hatással voltak a növényi növekedésre és biomassza produkcióra. A szelenátkezelés $20 \mu \mathrm{M}$-os koncentrációban szignifikáns növekedést indukált a növényi friss és száraz biomasszában mindkét szervben. Ezzel szemben a két magasabb kezelési koncentráció jelentősen csökkentette a növények biomasszáját gyökérben és hajtásban egyaránt. A szelenitkezelés koncentráció-függően csökkentette mindkét szerv friss és száraz tömegét, de itt nem volt mérhető pozitív növekedési válasz a szelenáttal ellentétben (9. ábra). 

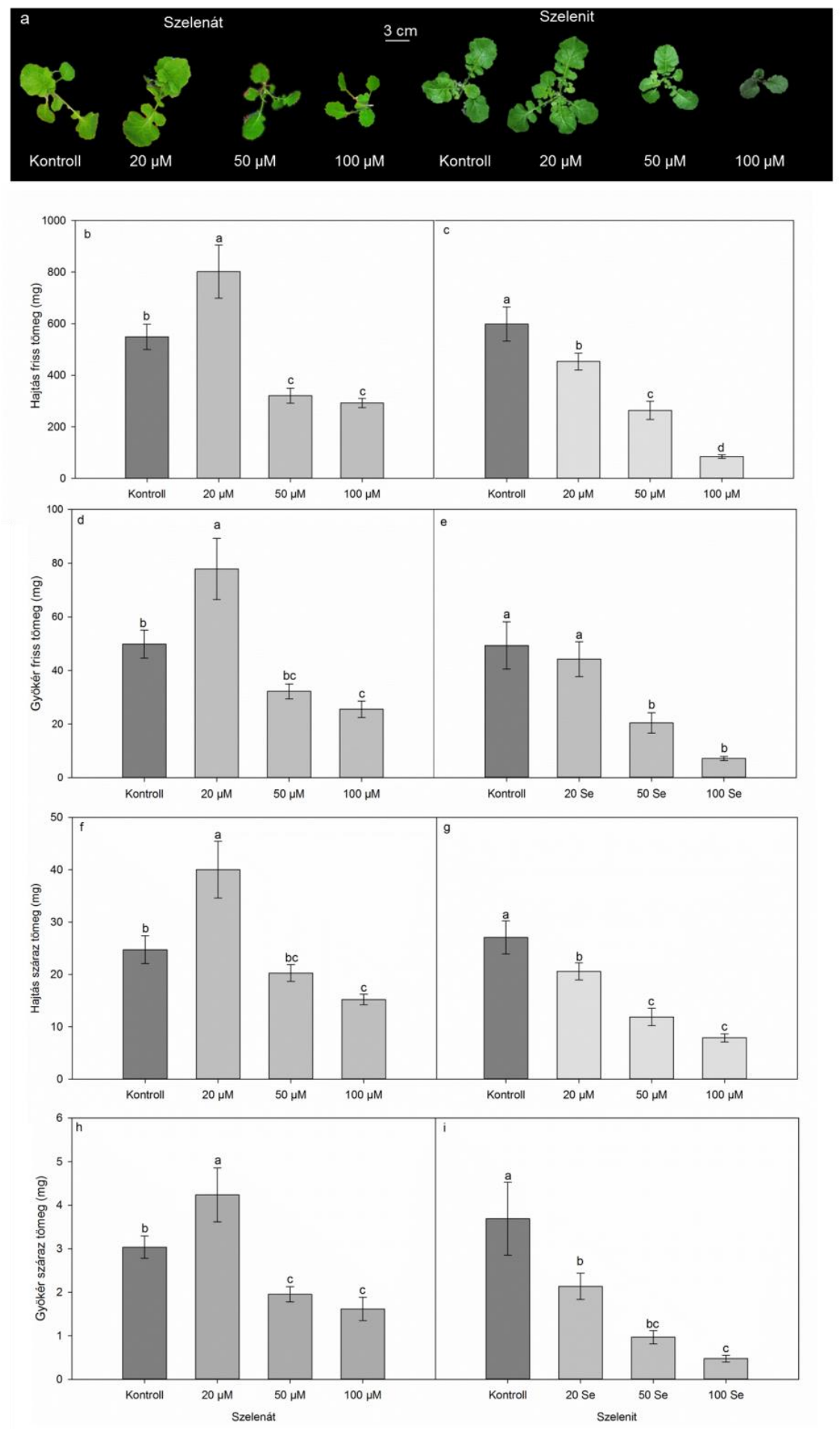

9. ábra Különböző koncentrációjú szelénformákkal 14 napig kezelt Brassica juncea növények növekedési paraméterei. A hajtásokról készült reprezentatív fotók $(\mathrm{a}$, mérce $=3 \mathrm{~cm})$ hajtás $(\mathrm{b}, \mathrm{c})$ és gyökér friss tömeg $(\mathrm{d}, \mathrm{e})$, valamint a hajtás (f,g) és gyökér száraz tömegei (h,i). A különböző betük statisztikailag szignifikánsan különbözö adatsorokat jelölnek a Duncan teszt alapján $(n=15, P \leq 0,05)$. 
A növények toleranciaindexe - mely a fögyökér kezelés hatására bekövetkező rövidüléséből számolandó - csökkent minden kezelés hatására a kontrollhoz képest, bár a csökkenés mértéke jelentősen kisebb mértékü szelenátkezelés esetén (10. ábra a). A gyökérmerisztéma életképessége hasonlóan alakult, hiszen a szelenátkezelés a merisztéma életképességének 17-22\%-os csökkenését vonta maga után, de ez nem bizonyult szignifikáns különbségnek a kontrollhoz képest egyik kezelési koncentrációban sem. A szelenitkezelés 50 és $100 \mu \mathrm{M}$-os koncentrációban szignifikánsan csökkentette a növények életképességét. (10. ábra $b, c)$. 

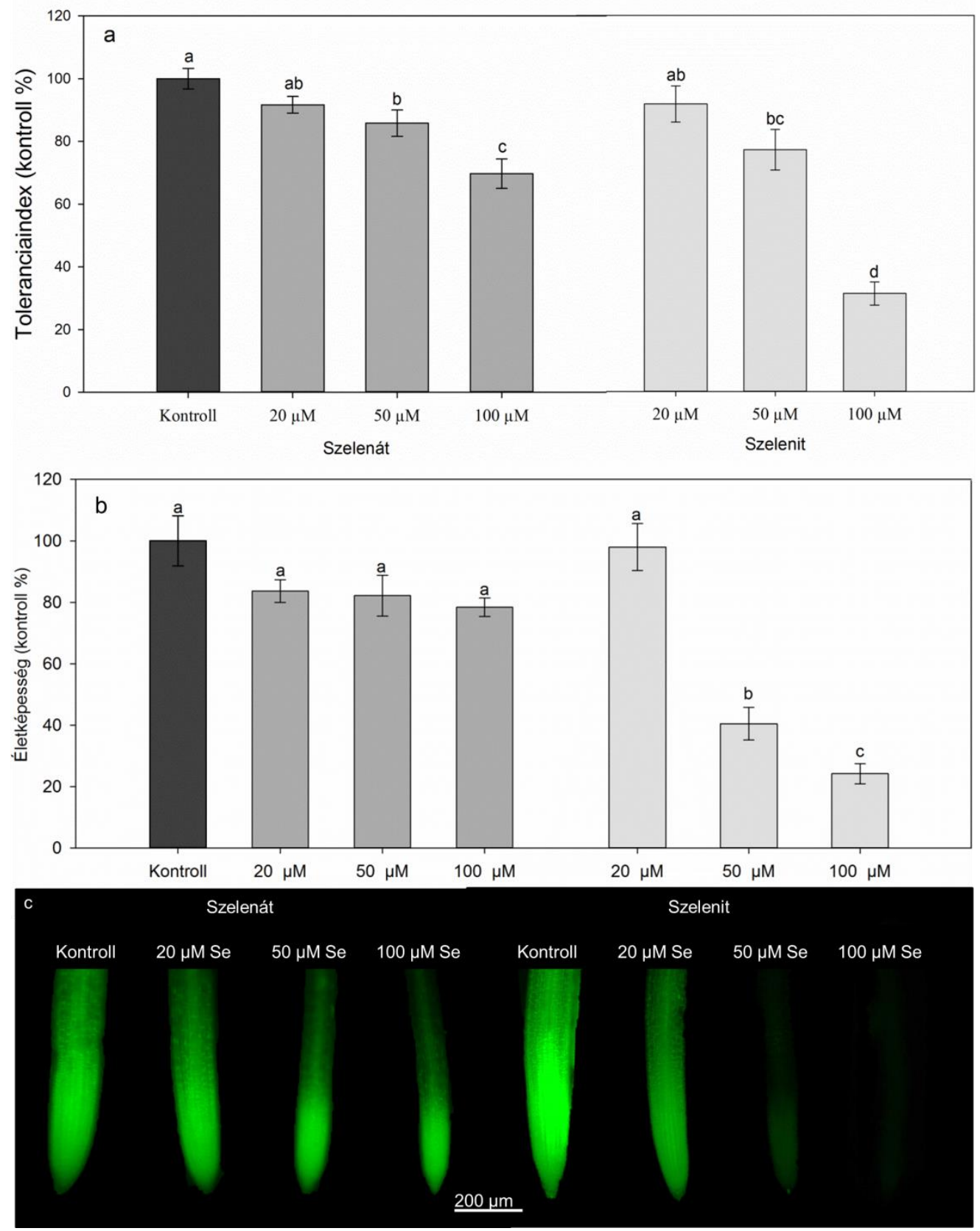

10. ábra Különböző szelénformákkal, 14 napig kezelt Brassica juncea növények toleranciaindexe (\%, a), valamint a gyökérmerisztéma életképessége (kontroll \%, b). A különbözö betük statisztikailag szignifikánsan különbözö adatsorokat jelölnek a Duncan teszt alapján ( $\mathrm{n}=15, \mathrm{P} \leq 0,05)$. (c) Reprezentatív mikroszkópos felvételek FDA-jelölt, kontroll és szelénkezelt Brassica juncea gyökércsúcsokról. Mérce $=200 \mu \mathrm{m}$.

A nitro-oxidatív jelátvitel endogén molekulái közül a NO szintje nem változott statisztikailag szignifikáns módon a gyökércsúcsokban egyik kezelés hatására sem (11. ábra a,b). A $\mathrm{O}_{2}{ }^{-}$-szint szelenátkezelés hatására szintén nem változott, de a $100 \mu \mathrm{M}$ szelenitkezelés egy jelentős növekedést okozott a $\mathrm{O}_{2}{ }^{-}$szintjében (11. ábra c,d). A két molekula reakciójából jöhet 
létre a $\mathrm{ONOO}^{-}$, mely szelenát hatására 50 és $100 \mu \mathrm{M}$-os kezelési koncentrációk esetén statisztikailag szignifikáns módon csökkent a kontrollhoz képest, míg a szelenit terhelés koncentrációfüggő növekedést okozott és a két nagyobb kezelési koncentráció szignifikánsan megnövelte a $\mathrm{ONOO}^{-}$szintet a kontrollhoz képest (11. ábra e,f,g). 

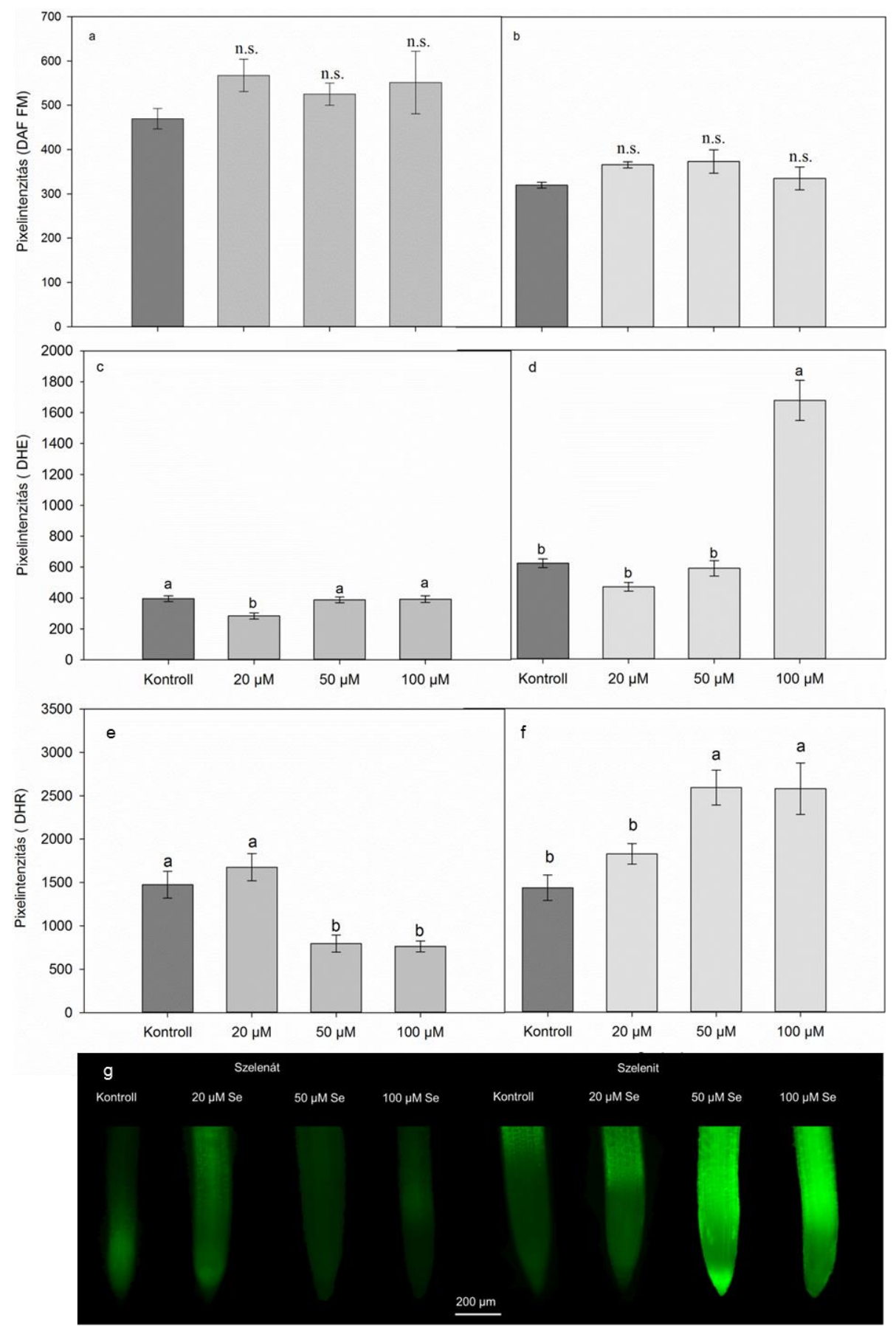

11. ábra A nitrogén-monoxid (a,b), szuperoxid gyökanion (c,d), peroxinitrit (e,f) szintjének alakulása 14 napos szelenit- és szelenátkezelések hatására Brassica juncea gyökerekben. A különböző betűk statisztikailag szignifikánsan különböző adatsorokat jelölnek a Duncan teszt alapján, míg az n.s. nem szignifikáns különbséget jelöl (n=10, P $\leq 0,05)$. (g) Reprezentatív mikroszkópos felvételek a DHR-jelölt Brassica juncea gyökércsúcsokról. Mérce $=200 \mu \mathrm{m}$.

A gyökérmerisztéma glutationszintje megváltozott a ROF metabolizmusának változásával. A szelenátkezelés statisztikailag nem szignifikáns csökkenést okozott a glutationszintben, míg a 
szelenitkezelés esetében minden kezelési koncentráció csökkentette az antioxidáns szintjét, melyek közül az 50 és $100 \mu \mathrm{M}$-os kezelés esetén statisztikailag szignifikáns csökkenés volt detektálható kontroll értékekhez képest (12. ábra).

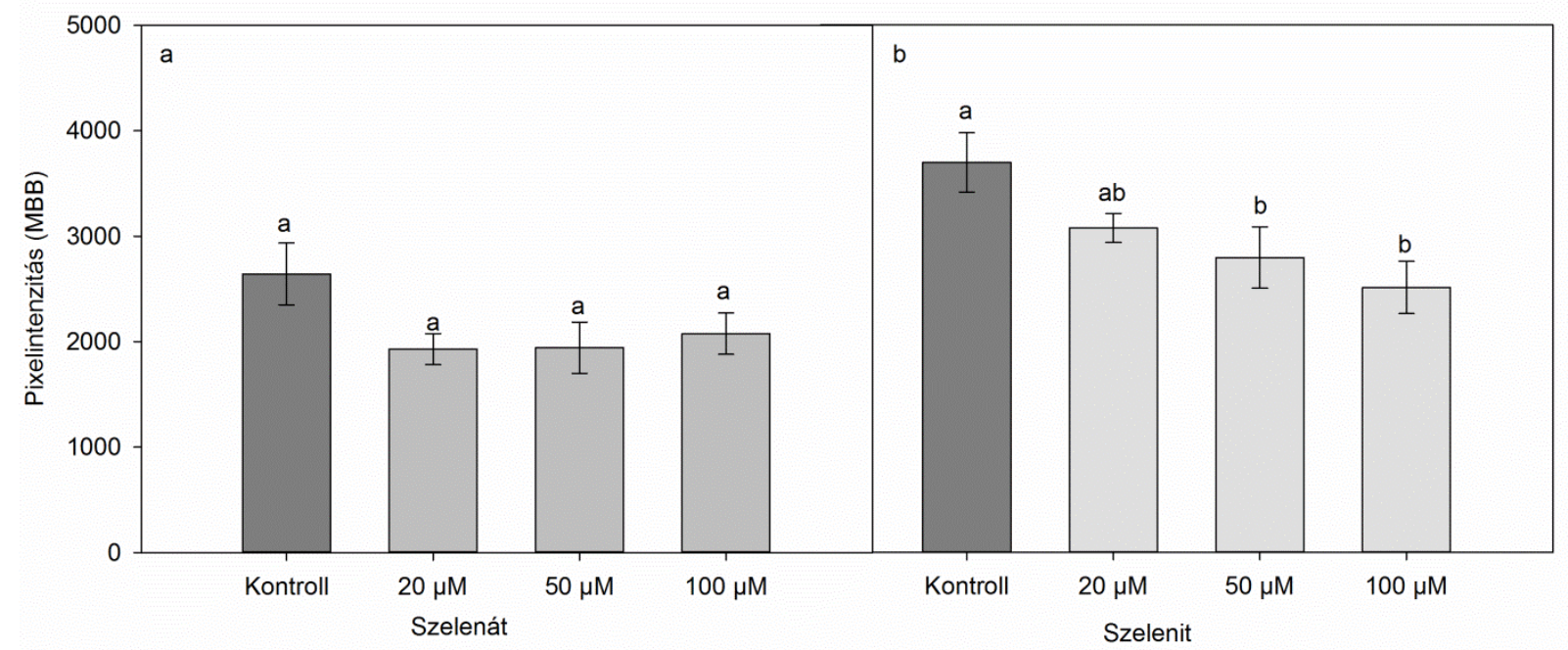

12. ábra A szelenát (a) és szelenit (b) kezelést kapott Brassica juncea növények gyökér merisztémájában detektált glutation mennyisége monobromobimán (MBB) festéssel kimutatva. A különböző betük statisztikailag szignifikánsan különböző adatsorokat jelölnek a Duncan teszt alapján (n=10, $\mathrm{P} \leq 0,05)$.

A nitro-oxidatív jelátvitel leggyakrabban vizsgált fehérje szintü következménye a proteintirozin-nitráció (PTN). A PTN mintázat levélben szelenát hatására nem változott jelentősen a nagymennyiségü akkumulált szelén ellenére sem, míg a szelenitkezelés jelentősen megnövekedett nitrációt okozott a kezeletlen növényekhez képest. Megváltozott továbbá a nitrációs mintázat is, mivel két fehérjesáv nitrációja csökkent, melyet fehér nyíllal jelöltünk, míg $100 \mu \mathrm{M}$-os kezelés hatására egy megközelítőleg $60 \mathrm{kDa}$ méretü új fehérjesáv is megjelent. Gyökérben a szelenátkezelés csupán a két nagyobb kezelési koncentráció esetében növelte meg a PTN-t a kontrollhoz képest, itt az $50 \mu \mathrm{M}$-os kezelés bizonyult jelentősebbnek. Szelenit esetében minden kezelési koncentráció megnövelte a nitrált fehérjék mennyiségét (13. ábra). 

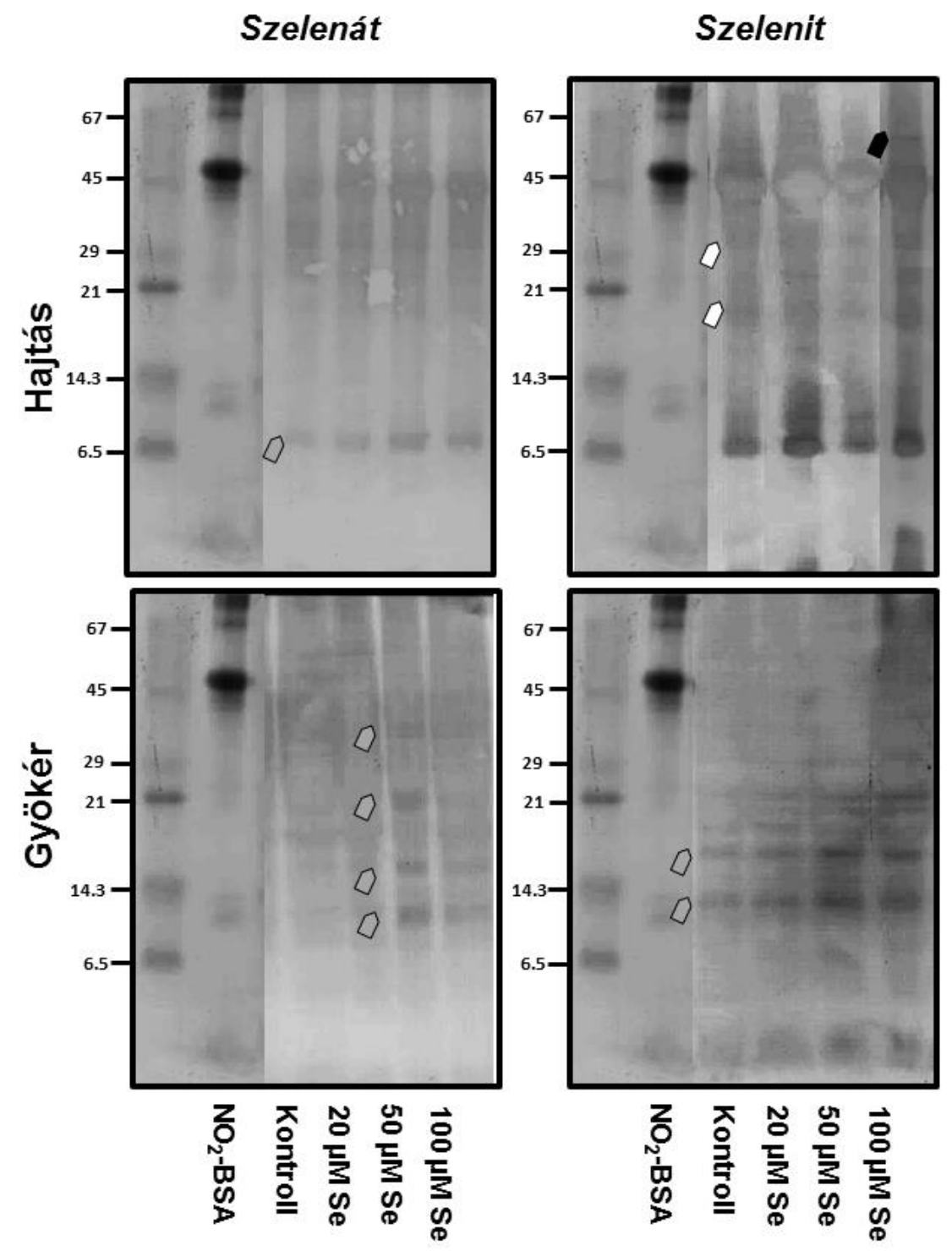

13. ábra Különbözö Brassica juncea szervek proteintirozin-nitrációs mintázata 14 nap, különböző mennyiségű és típusú szelénnel végzett kezelés után. A szürke nyilak a kezelés hatására megnövekedett immunopozitivitást mutató nitrált fehérjesávokat jelölnek, míg a fehér nyilak a kezelés hatására csökkenő nitrációt mutató fehérjesávokat jelölnek. A fekete nyíl egy újonnan nitrálódott fehérjesávot mutat. Kontrollként kereskedelmi nitrált borjú szérum albumint alkalmaztunk, aminek segítségével megfigyelhető, hogy az előhívási reakció hatására a nitrált fehérjék környezetében fekete formazán rakódott le a membránon. 


\section{2. Különböző szelénérzékenységü növények összehasonlítása a}

\section{keresztesvirágúak családjában}

Az alkalmazott második kísérleti rendszerben célunk volt összevetni két, eltérő szelén érzékenységü, Brassicaceae családba tartozó növényfaj, az Arabidopsis thaliana modell, és a Brassica juncea szelénre (7 napos szelenát kezelés) adott válaszait, különös tekintettel a nitrooxidatív jelátvitelre.

A szelén nem esszenciális mikroelem a magasabbrendü növények számára, így az előző kísérleti rendszerhez hasonlóan az első fontos vizsgálandó paraméter a növények szelénfelvétele volt. Az Arabidopsis thaliana és a Brassica juncea is képes volt nagy mennyiségü szelént felvenni a gyökerébe minden kezelési koncentráció esetében, de a hajtásba történő transzlokációjuk gyenge volt. Megemlítendő, hogy a legtöbb szelént a $100 \mu \mathrm{M}$ szelenittel kezelt mustár raktározta a gyökerében (14. ábra).
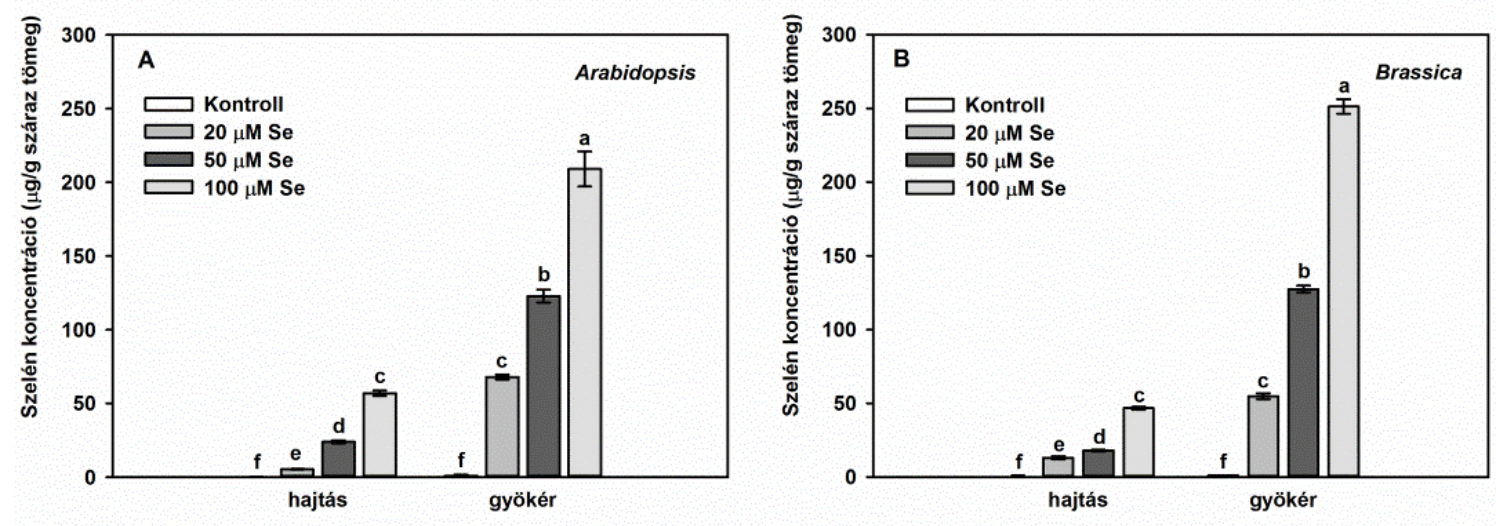

14. ábra Arabidopsis thaliana (a) és Brassica juncea (b) növények hajtásának és gyökerének szeléntartalma 7 nap szelenitkezelés hatására. A Duncan teszt alapján statisztikailag különböző adatokat külön betüvel jelöltem $(\mathrm{n}=6$, $\mathrm{P} \leq 0,05)$.

A felvett szelén hatással volt a növények biomassza-termelésére. A modellnövény esetében (15. ábra a,c,e) a $20 \mu \mathrm{M}$-os szelenit kezelés nem okozott számottevő változást egyik szervben sem, ezzel szemben az 50 és $100 \mu \mathrm{M}$-os kezelés csökkentette a hajtás és gyökér friss tömegét, bár statisztikailag csupán a gyökérnél volt szignifikáns a változás. A hajtásban, bár a friss tömeg nem mutatott szignifikáns változást, a levelek száraztömege csökkent a nagyobb kezelések hatására. 
Indiai mustárban a hajtás esetében sem a $20 \mu \mathrm{M}$-os, sem az $50 \mu \mathrm{M}$-os szelenitkezelés nem okozott jelentős változást, alátámasztva a növény erősebb stressztürését. A gyökérrendszerben a két nagyobb dózisú kezelés csökkentette számottevően a biomasszát, s a száraztömeg is csökkent a $100 \mu \mathrm{M}$-os kezelés hatására (15. ábra b,d,e).
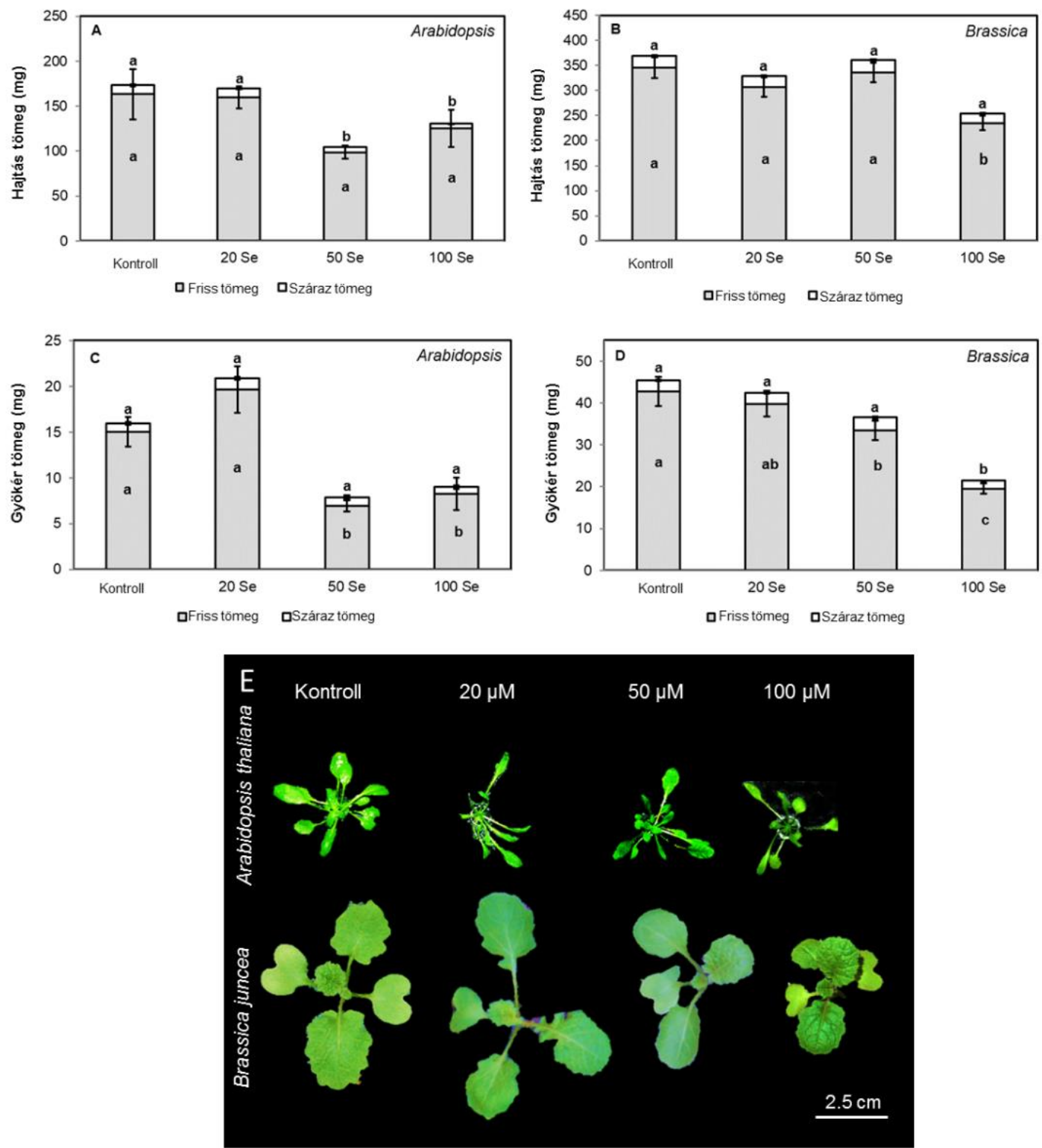

15. ábra A vizsgált növényfajok (Arabidopsis thaliana és Brassica juncea) hajtás $(\mathrm{a}, \mathrm{b})$ valamint gyökér $(\mathrm{c}, \mathrm{d})$ friss- és száraztömege 7 nap szelenit kezelés hatására, valamint a növények hajtásáról készült reprezentatív fotók (mérce $=2,5$ $\mathrm{cm}$, e). A statisztikailag szignifikánsan különböző adatokat külön betủvel jelöltük, az alkalmazott vizsgálat a Duncan teszt. $(n=20, P \leq 0,05)$ 
Lúdfü esetében az főgyökérhossz koncentrációfüggően csökkent a kezelés hatására, melyhez a nagyobb kezeléseknél csökkent oldalgyökérszám is társult, jól ábrázolva a növényfaj szelénérzékenységét (16. ábra a). Ezzel szemben indiai mustárnál a $20 \mu \mathrm{M}$-os kezelési koncentráció pozitív hatásúnak bizonyult, megnövelve a növények fögyökér hosszát az oldalgyökérszám változása nélkül. A két nagyobb kezelési koncentráció csökkentette a főgyökérhosszt és az oldalgyökerek száma enyhén megnött (16. ábra b). A gyökérmerisztéma életképessége mindkét növénynél csökkent a kezelések hatására, kivéve az indiai mustár $20 \mu \mathrm{M}$ os kezelési koncentrációjánál, ahol kontroll közeli maradt. Megemlítendő, hogy a $100 \mu \mathrm{M}$-os kezelés csak 50\% körüli életképesség csökkenéssel járt a mustárnál, míg a lúdfü ennél sokkal számottevőbb csökkenést szenvedett el (16. ábra c,d,e).
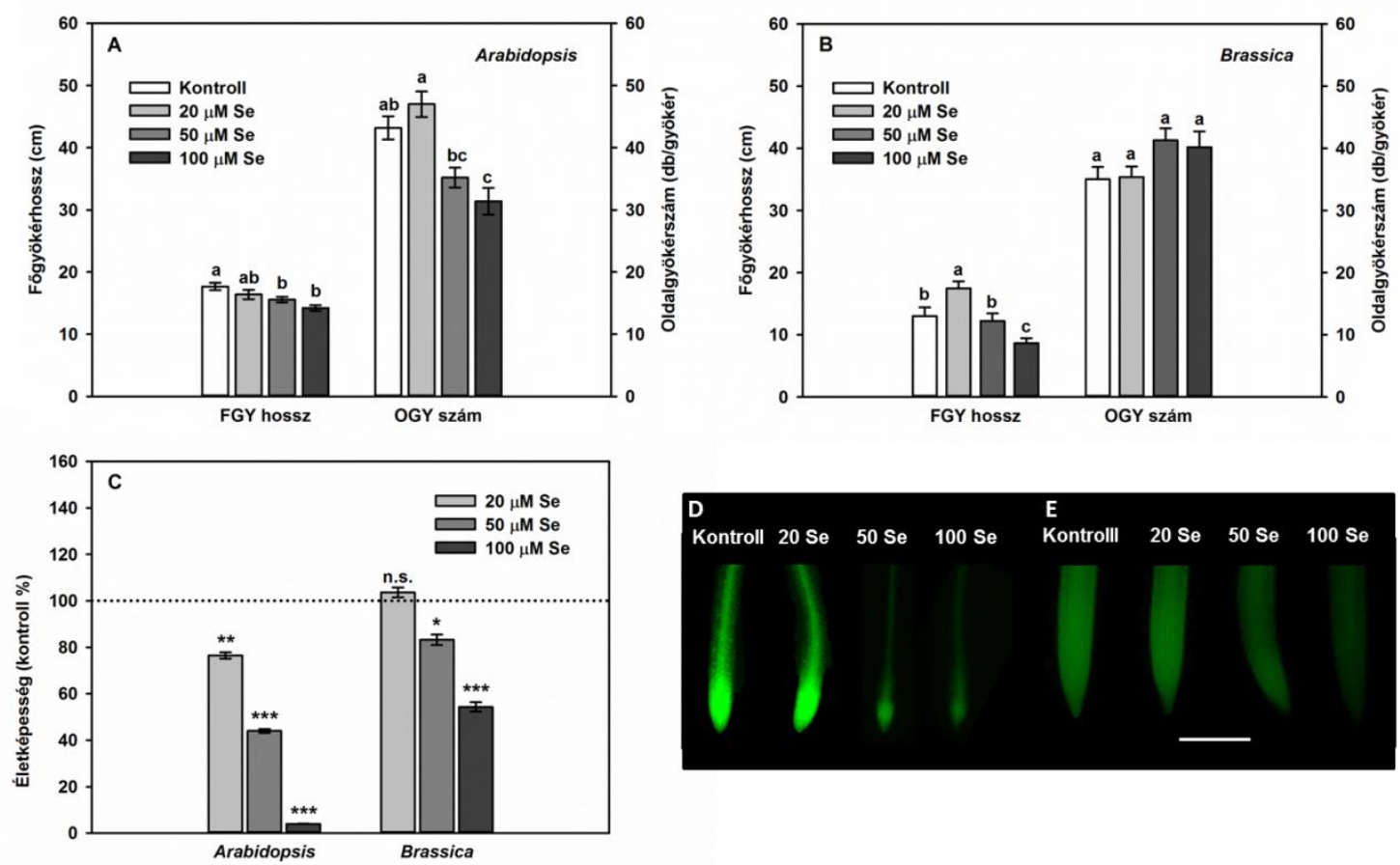

16. ábra A vizsgált növényfajok (Arabidopsis thaliana, Brassica juncea) fögyökérhossza, valamint az oldalgyökérszáma $(\mathrm{a}, \mathrm{b}) 7$ nap szelenitkezelés hatására. Duncan teszttel bizonyított statisztikailag szignifikáns adatsorokat különböző betüvel jelöltem $(n=20, P \leq 0,05)$. A gyökerek csúcsi merisztémájának életképessége (kontroll\%, c), valamint az ezekhez tartozó reprezentatív, mikroszkópos fotók az FDA-festett gyökércsúcsokról (mérce $=200 \mu \mathrm{m}, \mathrm{d}, \mathrm{e})$. Az adatok Student féle T-próbával lettek elemezve, melynél a statisztikailag szignifikánsan különböző adatokat csillaggal jelöltem $(n=10, * P \leq 0,05, * * P \leq 0,01, * * * P \leq 0,001)$.

A sztómamüködés különösen fontos szelénstressz esetén, hiszen nemcsak a fotoszintézishez szükséges gázokat biztosítja, de a volatilizációval a szeléndetoxifikáció egyik útvonala is lehet. Lúdfüben a sztómaszám minden kezelési koncentráció hatására csökkent, míg a gázcserenyílások 
nyitottsága ezzel párhuzamosan jelentősen nőtt (17. ábra a,c). Ezzel szemben indiai mustárnál mind a sztómaszám, mind a gázcserenyílások nyitottsága megnőtt a kontrollhoz képest, főként a 20 és $100 \mu \mathrm{M}$-os kezelési koncentrációk esetében, ahol a kontrolltól való eltérés statisztikailag szignifikáns volt (17. ábra b,d). A Brassica levelek esetében megfigyelt rózsaszín levélfonák is elemzésre került, s adataink alapján ezt antocián feldúsulás okozhatta (17. ábra i,j), mely főleg az epidermiszsejtekben volt megfigyelhetö. 

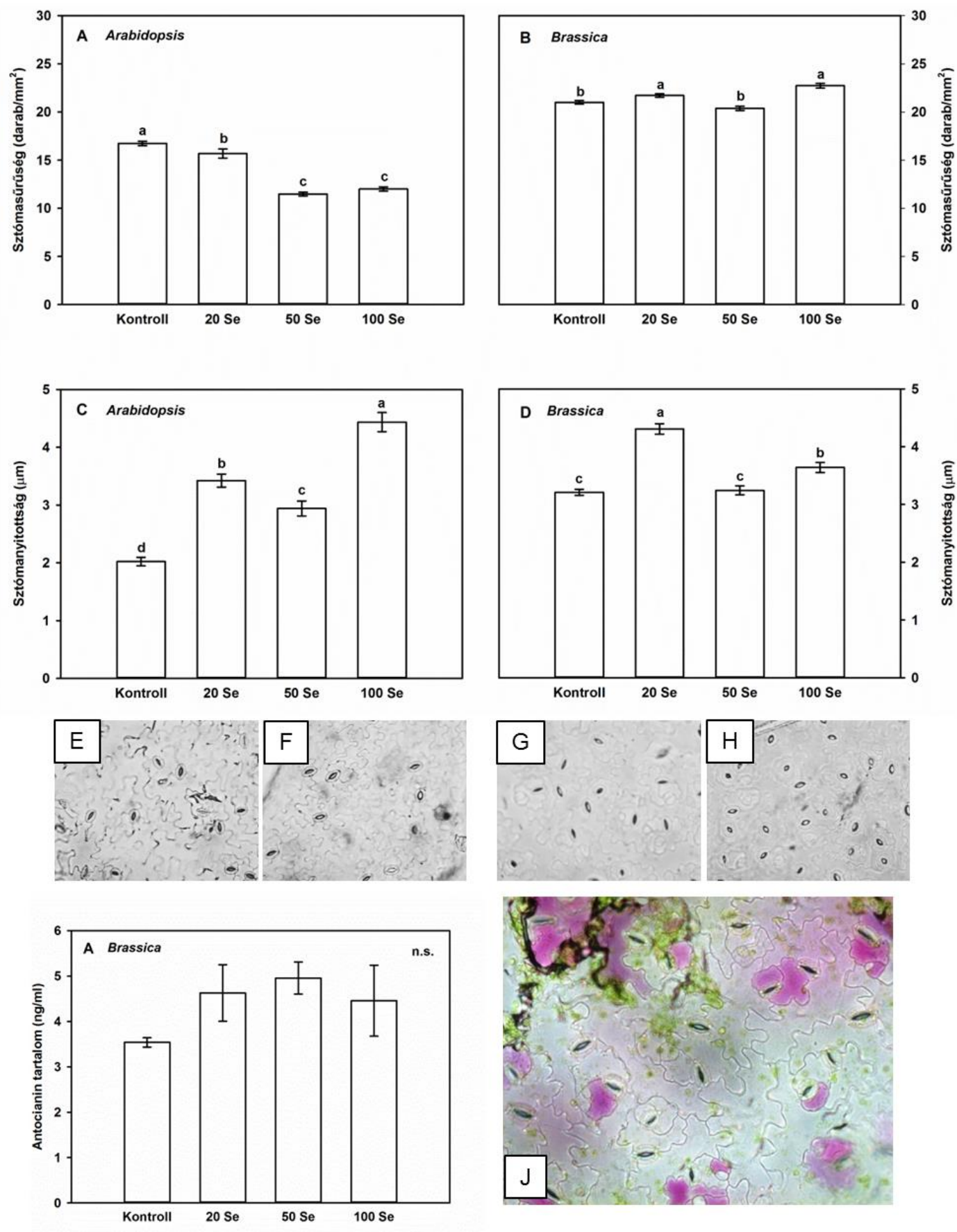

17. ábra Szelenittel kezelt Arabidopsis thaliana és Brassica juncea növények sztómasürüsége (a,b) és a sztómanyílás mérete (c,d). Bemutató felvételek a kontroll (e) és $100 \mu \mathrm{M}$ szelenittel kezelt Arabidopsis thaliana (f), valamint kontroll $(0 \mu \mathrm{M})(\mathrm{g})$ és $100 \mu \mathrm{M}(\mathrm{h})$ kezelést kapott mustárnövények epidermisz nyúzatairól. Az indiai mustár leveleinek antociántartalma (i), valamint egy reprezentatív fotó, mely bemutatja a rózsaszín antociánfeldúsulást a levélepidermiszben (j). A különbözö betük Duncan teszt alapján statisztikailag különbözö adatokat jelölnek, míg az n.s. jelölés statisztikailag nem szignifikáns különbségeket mutat ( $\mathrm{n}=20(\mathrm{a}-\mathrm{d}), \mathrm{n}=6(\mathrm{i}), \mathrm{P} \leq 0,05$, mérce $=50 \mu \mathrm{m})$. 
A növényi sejtfalnak jelentős szerepe van a nehézfémek megkötésében, így összetételét illetve abban beálló változásokat megvizsgáltuk a szelénstressz hatására. Lúdfüben a gyökércsúcsok pektintartalma csupán az $50 \mu \mathrm{M}$-os kezelési koncentrációnál változott meg, ahol a gyökérsüveg- és merisztémazónákban volt egy kisebb felhalmozódás, amit a rózsaszín elszíneződés jelez (18. ábra a). Ezzel szemben indiai mustárnál a $20 \mu \mathrm{M}$-os kezelés minden gyökérzónában jelentősen megnövelte a pektintartalmat, de ez az 50 és $100 \mu \mathrm{M}$-os kezelésnél inkább az elongációs zónára korlátozódott (18. ábra b). A lúdfügyökerek kallóztartalma minden kezelés hatására jelentősen megnövekedett, ezzel szemben az indiai mustár csupán a legnagyobb kezelési koncentráció hatására növelte meg e sejtfalalkotó mennyiségét (18. ábra c).

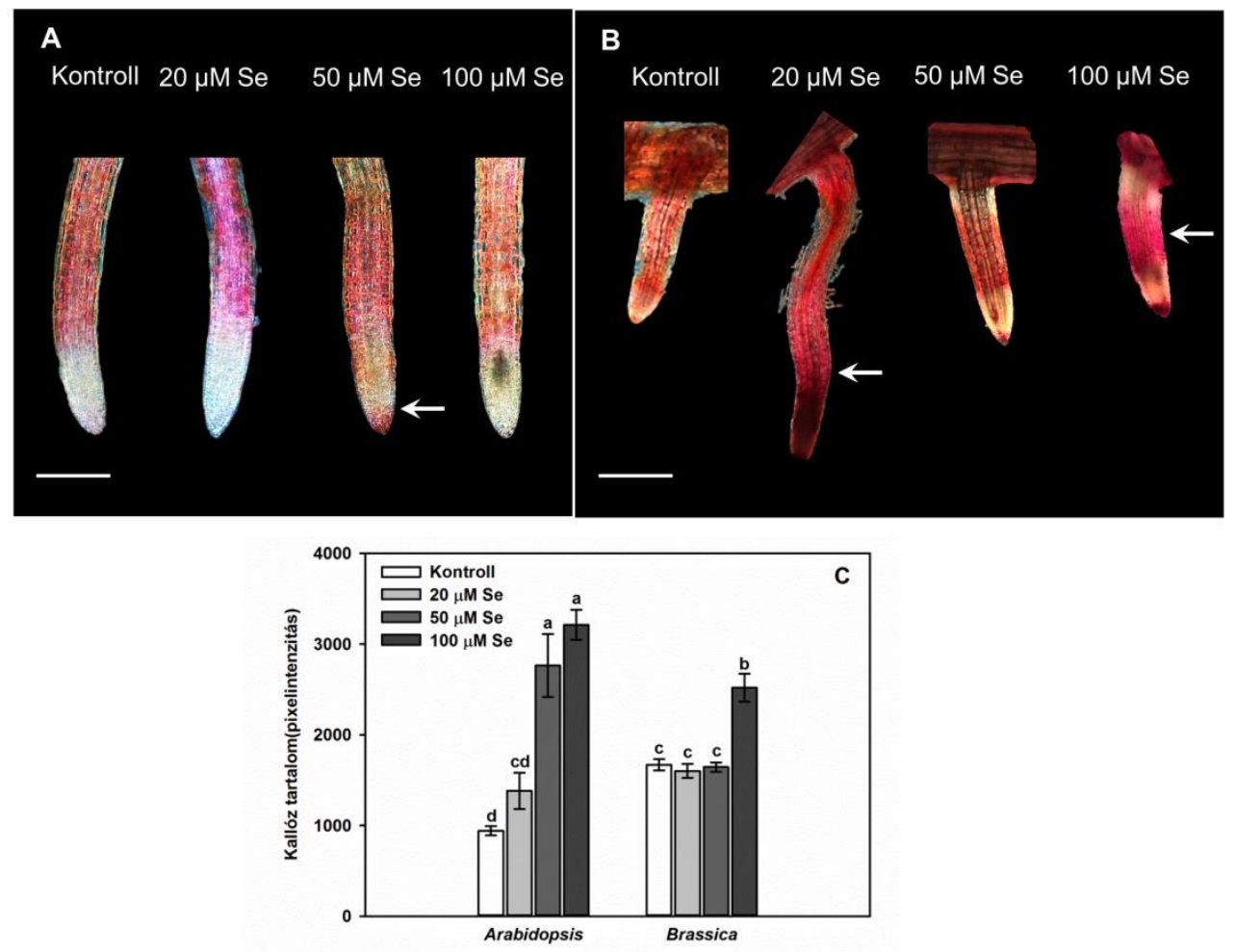

18. ábra Pektinakkumuláció Arabidopsis thaliana (a) és Brassica juncea (b) növények gyökércsúcsában Ruténium vörössel kimutatva. A fehér nyilak kontroll növényekhez mérten jelentős pektin akkumulációt jelölnek (mérce $=150$ $\mu \mathrm{m})$. A növényi gyökérmerisztéma kallóztartalma (c) anilinkék festékkel kimutatva. A különböző betük Duncan teszt alapján szignifikánsan különböző adatsorokat jelölnek ( $\mathrm{n}=10, \mathrm{P} \leq 0,05)$.

A ROF és az oxidatív stresszjelátvitel jelentős sejtélettani változásokat okozhat, így ez is vizsgálataink tárgyát képezte. $\mathrm{A} \mathrm{O}_{2}{ }^{-}$-szint szignifikánsan nőtt a lúdfü esetében minden kezelési koncentráció esetében, ezzel ellentétben a mustárnál csupán a $100 \mu \mathrm{M}$-os kezelés okozott jelentős 
emelkedést (19. ábra a,b). A $\mathrm{H}_{2} \mathrm{O}_{2}$ szint szintén megváltozott a kezelések hatására. Mindkét növényfajban minden koncentráció $\mathrm{H}_{2} \mathrm{O}_{2}$-szint-emelkedést indukált, mely statisztikailag szignifikánsnak csupán a nagyobb kezelési koncentrációknál bizonyult (19. ábra c,d). A növények glutationtartalma lúdfünél csak a legnagyobb, míg indiai mustárnál már az $50 \mu \mathrm{M}$-os kezelés hatására is csökkent, sugallva a jelentős oxidatív stresszt, mely a szelén hatására kialakult (19. ábra e,f). A peroxidázok szerepe sokrétü a sejtfal összetételének befolyásolásánál, de képesek nagy mennyiségü ROF elbontására, így fontos szerepük van az oxidatív stressz esetében is. A peroxidáz aktivitás mindkét növényfajban jelentősen nőtt, főleg a nagyobb kezelési koncentrációknál. Megemlítendő, hogy indiai mustárban az aktiválódás sokkal intenzívebb volt, mint lúdfüben (20. ábra a,b). A lipid peroxidáció mindkét növényfajban minden kezelési koncentráció hatására létrejött, ezzel is bizonyítva a növényekben lezajló jelentős oxidatív stresszt (20. ábra c,d). 

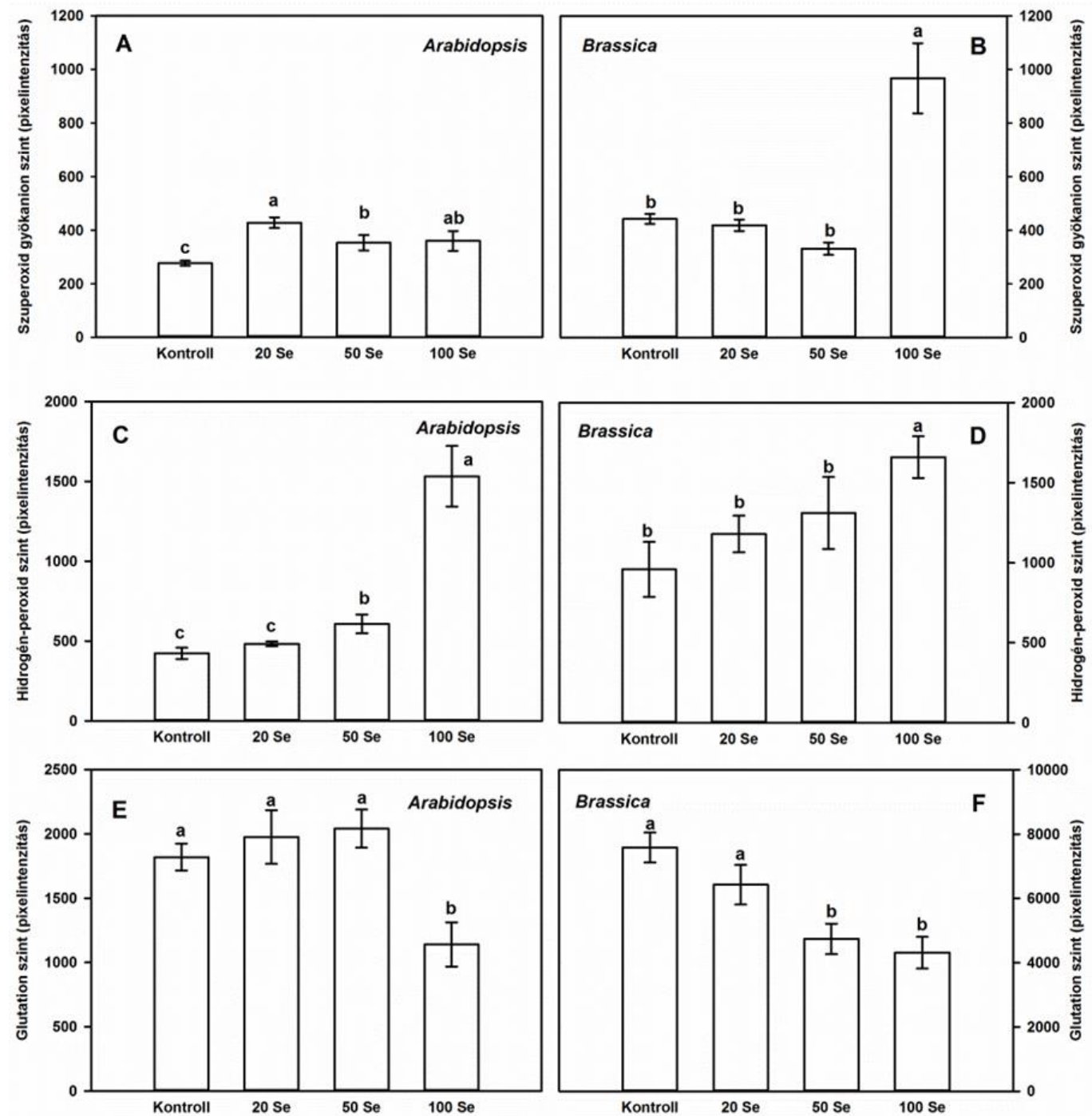

19. ábra Szuperoxid gyökanion- (a,b), hidrogén-peroxid- (c,d) és glutationszint (e,f) Arabidopsis thaliana és Brassica juncea gyökerekben 7 napos szelenitkezelést követően. A statisztikailag szignifikáns adatsorokat Duncan teszttel vizsgáltam, és a különböző adatsorokat különböző betűvel jelöltem ( $\mathrm{n}=10, \mathrm{P} \leq 0,05)$. 

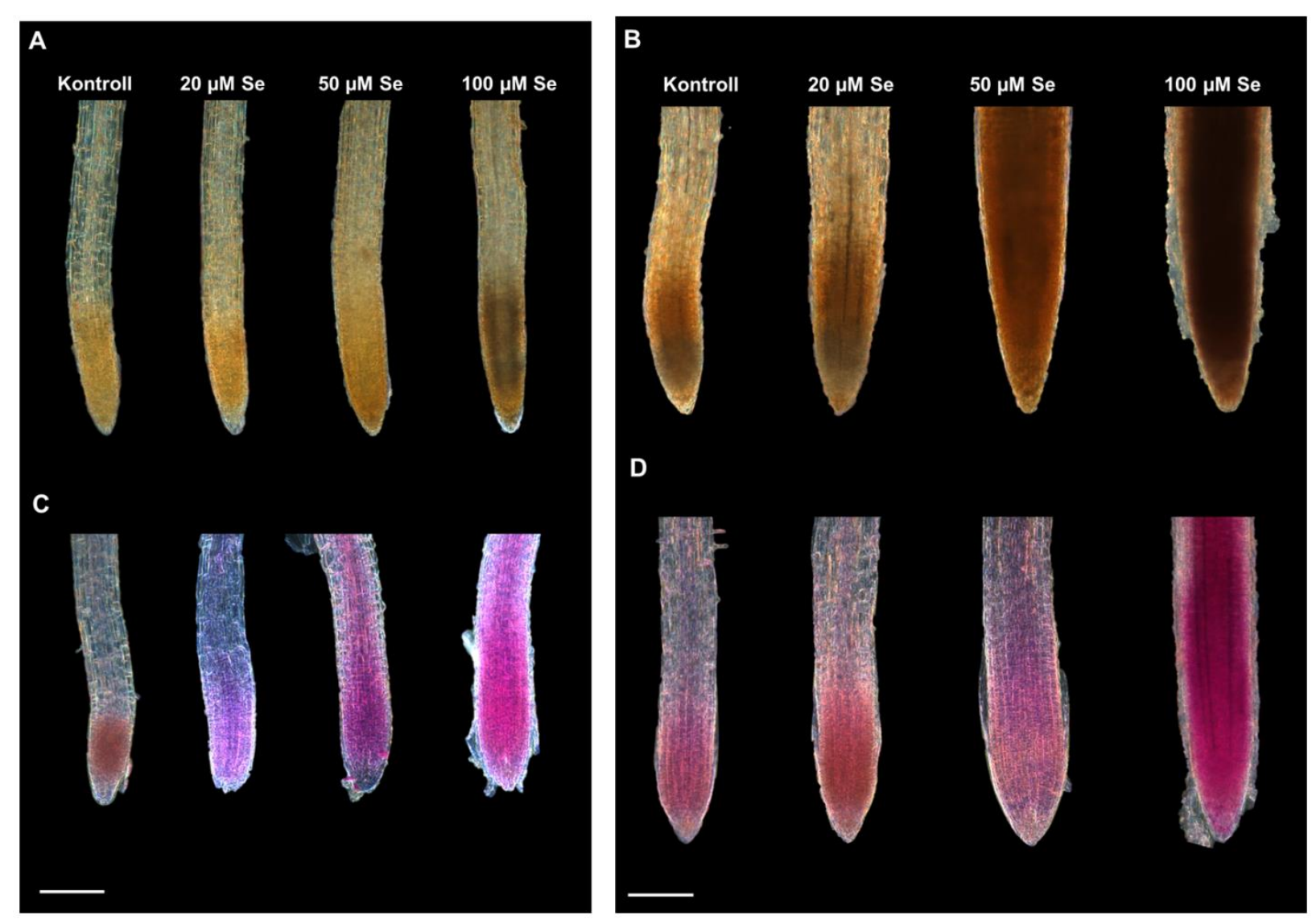

20. ábra Sejtfali peroxidázaktivitás kimutatása pirogallollal Arabidopsis thaliana (a) és Brassica juncea (b) gyökércsúcsokban. Lipidperoxidáció Arabidopsis thaliana (c) és Brassica juncea (d) gyökércsúcsokban. Mércék= $150 \mu \mathrm{m}$.

A RNF jelátvitele és a PTN is fontos, ám szelénterhelés hatására eddig ismeretlenek a másodlagos stresszfolyamatok, így vizsgáltuk az ezekben beálló változásokat. A NO-szint lúdfü esetében 20 és $50 \mu \mathrm{M}$-os szelenitkezelés hatására szignifikánsan csökkent a kontrollhoz képest, míg a legnagyobb kezelési koncentráció kontroll közeli szintet eredményezett. Mustár esetében nem voltak jelentősebb változások a NO-szintben egyik kezelési koncentrációnál sem (21. ábra a,b). A $\mathrm{ONOO}^{-}$-szint minden kezelési koncentráció hatására mindkét növényben emelkedett, s legjelentősebb mennyiségben mustárban volt (21. ábra c,d). A ONOO- által okozott PTN a kontrollnövényekhez viszonyítva mindkét fajban megváltozott. Lúdfü levelében két proteinsáv nitrációja növekedett, mely legjelentősebb az $50 \mu \mathrm{M}$ szelenitkezelés hatására volt. Indiai mustár esetében hét ilyen proteinsáv volt detektálható, valamint összességében is egy jelentősebb nitrációról beszélhetünk kontrollhoz képest. A lúdfü és mustár gyökerében is hat proteinsáv 
intenzitása nőtt meg a kezelések hatására, de itt is elmondható, hogy a mustár szelenit-indukált fehérje nitrációja jelentősebb volt, mint a lúdfüé (22. ábra).
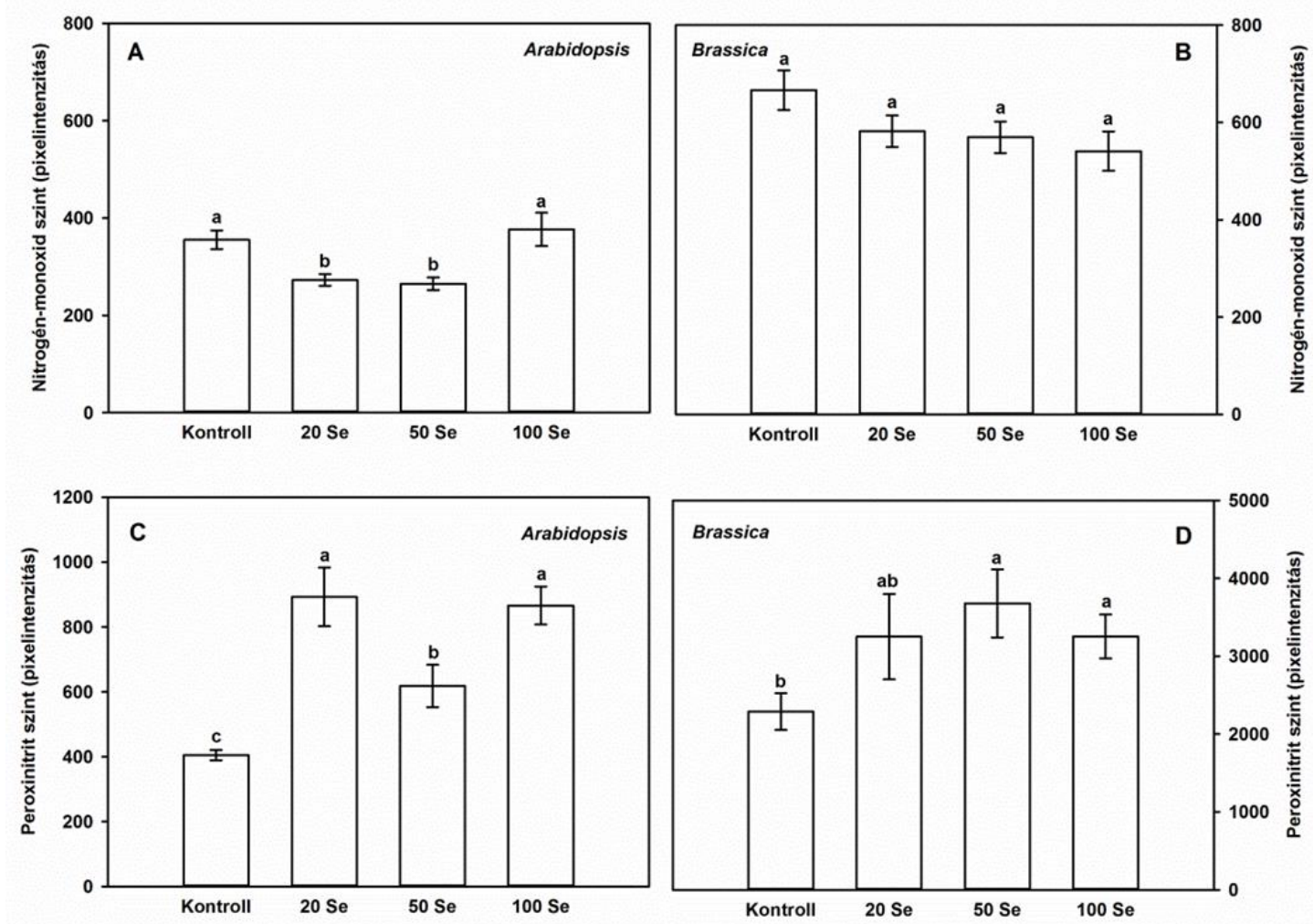

21. ábra A nitrogén-monoxid (a,b) és peroxinitrit szint (c,d) Arabidopsis thaliana és Brassica juncea növényekben 7 napos szelenitkezelés hatására. A statisztikailag szignifikánsan különböző adatsorok más betüvel kerültek jelölésre Duncan teszt alapján $(\mathrm{n}=10, \mathrm{P} \leq 0,05)$. 

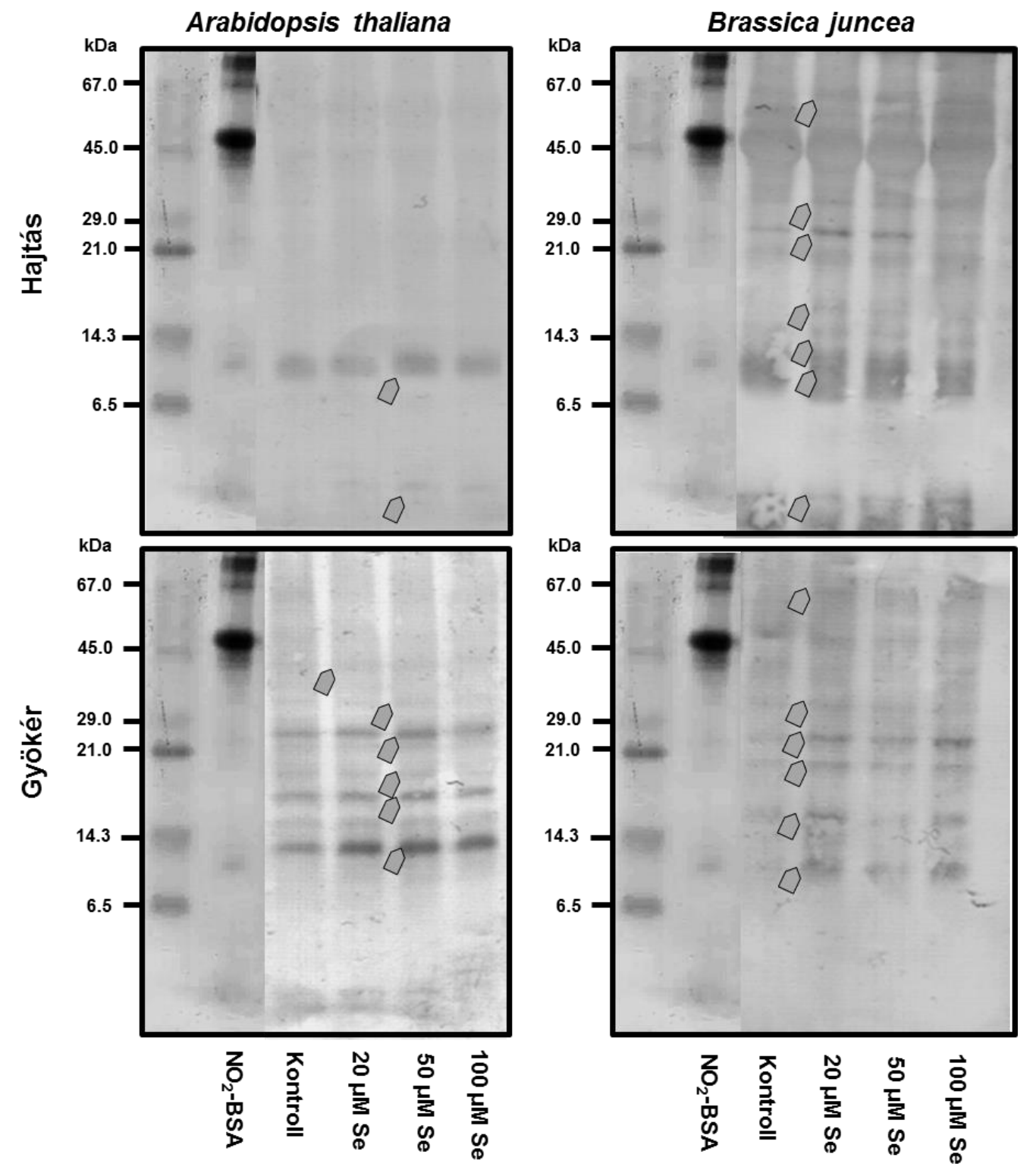

22. ábra A proteintirozin-nitráció kimutatása western blot analízissel, ahol az előhívás során fekete formazán keletkezett a 3- nitrotirozin elleni antitesttel jelölt fehérjék közelében a membránon. A szürke nyilak a kontrollhoz képest erősödő fehérjesávokat jelölnek, valamint pozitív kontrollként nitrált borjú szérum albumint használtunk. 


\section{3. Különböző szelénérzékenységü növények összehasonlítása a csüdfüvek családjában}

Kísérleteinket egy olyan rendszerben folytattuk, melyben szelén-hiperakkumuláló Astragalus bisulcatus és nem akkumuláló Astragalus membranaceus fajok szelenátterhelésre adott nitro-oxidatív válaszait hasonlítottuk össze.

A hiperakkumuláló és szelénérzékeny növények összehasonlitásához elsőként szükség volt a szelénakkumulációs képesség tanulmányozására. Mindkét növény képes volt felvenni a nem esszenciális nemfémes elemet, de az A. membranaceus inkább a gyökerében raktározta, kevésbé transzlokálta a sziklevelekbe, mint a toleráns hiperakkumuláló A. bisulcatus (23. ábra). A szelén képes befolyásolni más mikroelemek felvételét. A vizsgálatok kimutatták, hogy az $A$. membranaceus-ban jelentősen csökkent a $\mathrm{B}, \mathrm{Fe}, \mathrm{Zn}$ és Mn mennyisége a szelén kezelés hatására, míg A. bisulcatus-ban a mikroelem-homeosztázist kevésbé befolyásolta a szelenát. A szövetek molibdéntartalma A. membranaceus mindkét szervében és A. bisulcatus sziklevélben is megnövekedett a kontrollhoz képest (2. táblázat). 


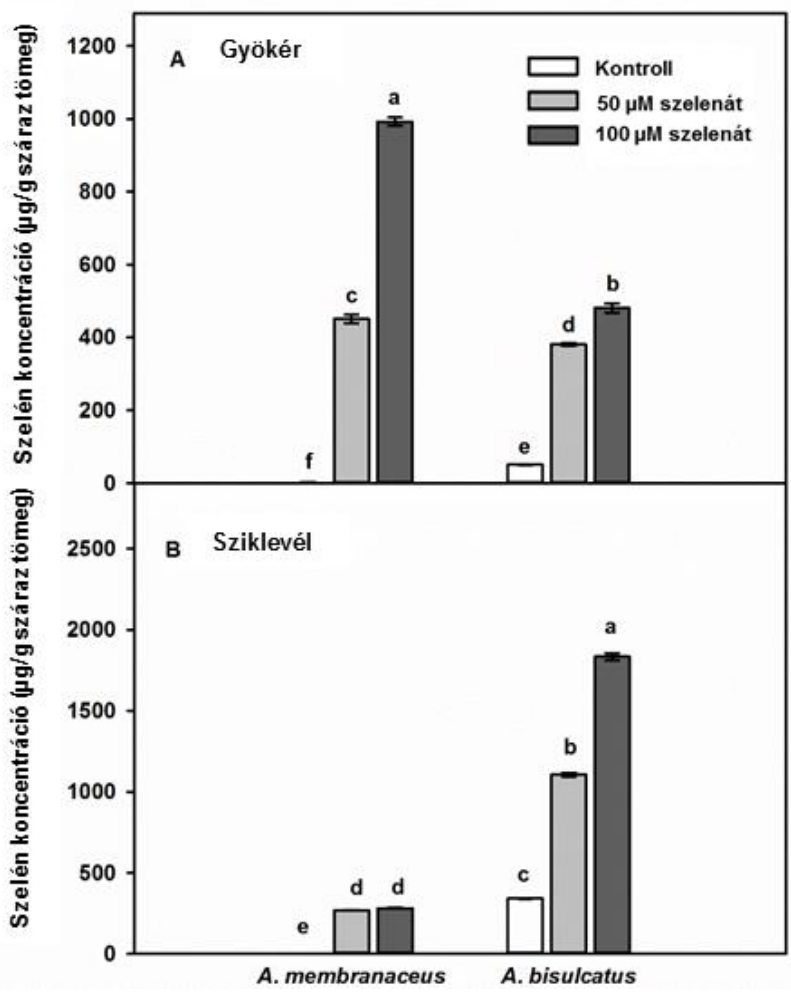

23. ábra Szelénkoncentrációk különböző szelénérzékenységü csüdfüfajok (Astragalus membranaceus és Astragalus bisulcatus) gyökerében (a) és sziklevelében (b). A különbözö betűvel jelölt adatsorok statisztikailag szignifikánsan különbözö adatsorokat jelölnek Duncan teszt alapján ( $\mathrm{n}=3, \mathrm{P} \leq 0,05)$. 


\begin{tabular}{|c|c|c|c|c|c|}
\hline & & \multicolumn{2}{|c|}{ A. membranaceus } & \multicolumn{2}{|c|}{ A. bisulcatus } \\
\hline & & sziklevél & gyökér & sziklevél & gyökér \\
\hline \multirow{3}{*}{$\begin{array}{c}\text { Vastartalom } \\
\text { ( } \mu \mathrm{g} / \mathrm{g} \text { száraz } \\
\text { tömeg) }\end{array}$} & Kontroll & $133,20 \pm 1,9^{a}$ & $503,80 \pm 8,3^{\mathrm{a}}$ & $108,23 \pm 2,4^{\mathrm{a}}$ & $963,60 \pm 25,7^{b}$ \\
\hline & $50 \mu \mathrm{M}$ Se & $65,35 \pm 0,6^{\mathrm{b}}$ & $338,81 \pm 11,3^{b}$ & $105,80 \pm 3,4^{\mathrm{a}}$ & $1234,00 \pm 14,7^{8}$ \\
\hline & $100 \mu \mathrm{M} \mathrm{Se}$ & $59,81 \pm 1,6^{\mathrm{c}}$ & $358,90 \pm 16,3^{b}$ & $95,47 \pm 0.4^{b}$ & $811,70 \pm 5,0^{c}$ \\
\hline \multirow{3}{*}{$\begin{array}{c}\text { Cinktartalom } \\
\text { ( } \mu \mathrm{g} / \mathrm{g} \text { száraz } \\
\text { tömeg) }\end{array}$} & Kontroll & $101,50 \pm 1,2^{\mathrm{a}}$ & $152,10 \pm 1,6^{b}$ & $73,97 \pm 0,7^{\mathrm{a}}$ & $336,00 \pm 5,2^{a}$ \\
\hline & $50 \mu \mathrm{M} \mathrm{Se}$ & $72,18 \pm 1,4^{b}$ & $145,51 \pm 2,1^{c}$ & $74,98 \pm 0,6^{\mathrm{a}}$ & $344,62 \pm 5,0^{\mathrm{a}}$ \\
\hline & $100 \mu \mathrm{M} \mathrm{Se}$ & $65,54 \pm 0,3^{\mathrm{c}}$ & $166,93 \pm 6,6^{a}$ & $73,58 \pm 0,7^{\mathrm{a}}$ & $295,28 \pm 0,4^{b}$ \\
\hline \multirow{3}{*}{\begin{tabular}{|c|} 
Mangán- \\
tartalom $(\mu \mathrm{g} / \mathrm{g}$ \\
száraz \\
tömeg) \\
\end{tabular}} & Kontroll & $106,61 \pm 0,4^{\mathrm{a}}$ & $129,63 \pm 1,8^{\mathrm{a}}$ & $102,88 \pm 4,9^{\mathrm{a}}$ & $147,3 \pm 2,3^{\mathrm{a}}$ \\
\hline & $50 \mu \mathrm{M} \mathrm{Se}$ & $85,94 \pm 0,7^{b}$ & $76,41 \pm 0,9^{b}$ & $107,86 \pm 0,6^{\mathrm{a}}$ & $90,08 \pm 5,6^{b}$ \\
\hline & $100 \mu \mathrm{M} \mathrm{Se}$ & $68,22 \pm 1,1^{c}$ & $60,57 \pm 1,1^{\mathrm{c}}$ & $99,92 \pm 0,2^{\mathrm{a}}$ & $96,65 \pm 1,8^{b}$ \\
\hline \multirow{3}{*}{$\begin{array}{c}\text { Bórtartalom } \\
\text { ( } \mu \mathrm{g} / \mathrm{g} \text { száraz } \\
\text { tömeg) }\end{array}$} & Kontroll & $113,84 \pm 0,7^{\mathrm{a}}$ & $51,62 \pm 0,2^{\mathrm{a}}$ & $46,26 \pm 1,9^{\mathrm{a}}$ & $47,35 \pm 4,7^{\mathrm{a}}$ \\
\hline & $50 \mu \mathrm{M}$ Se & $53,22 \pm 0,5^{b}$ & $51,55 \pm 1,3^{\mathrm{a}}$ & $47,77 \pm 0,2^{\mathrm{a}}$ & $31,68 \pm 2,1^{b}$ \\
\hline & $100 \mu \mathrm{M} \mathrm{Se}$ & $39,61 \pm 1,0^{\mathrm{c}}$ & $44,27 \pm 1,0^{b}$ & $43,53 \pm 0,5^{b}$ & $40,63 \pm 1,5^{\mathrm{a}}$ \\
\hline \multirow{3}{*}{\begin{tabular}{|c|} 
Molibdén- \\
tartalom $(\mu \mathrm{g} / \mathrm{g}$ \\
száraz \\
tömeg)
\end{tabular}} & Kontroll & $5,87 \pm 0,08^{b}$ & $2,88 \pm 0,1^{b}$ & $1,63 \pm 0,4^{\mathrm{a}}$ & $3,08 \pm 0,02^{\mathrm{a}}$ \\
\hline & $50 \mu \mathrm{M} \mathrm{Se}$ & $6,80 \pm 0,1^{\mathrm{a}}$ & $5,13 \pm 0,09^{a}$ & $2,13 \pm 0,2^{a}$ & $2,24 \pm 0,09^{b}$ \\
\hline & $100 \mu \mathrm{M} \mathrm{Se}$ & $6,88 \pm 0,09^{\mathrm{a}}$ & $5,02 \pm 0,2^{a}$ & $1,94 \pm 0,2^{\text {a }}$ & $2,21 \pm 0,1^{b}$ \\
\hline
\end{tabular}

2. táblázat Astragalus membranaceus és Astragalus bisulcatus szervenkénti Fe, Zn, Mn, B, Mo tartalma. Az adatok $\mu \mathrm{g} / \mathrm{g}$ száraz tömegben vannak kifejezve, a különböző betük pedig statisztikailag különböző adatsorokat jelentenek a Duncan teszt alapján. $(n=3, P \leq 0,05)$

A felvett szelén és a mikroelemek homeosztázisának változása befolyásolta a növények fiziológiás életmüködését. A nem akkumuláló A. membranaceus csírázása, valamint a hajtás és gyökér friss tömege is szignifikánsan csökkent a kontrollnövényekhez képest szelenátkezelés hatására. Ezzel szemben az A. bisulcatus csírázása és a sziklevelek friss tömege nem változott jelentősen a kezelések hatására. A gyökerek friss tömege csökken a kezelések hatására, de sokkal kisebb mértékben, mint az A. membranaceus esetén (24. ábra). 

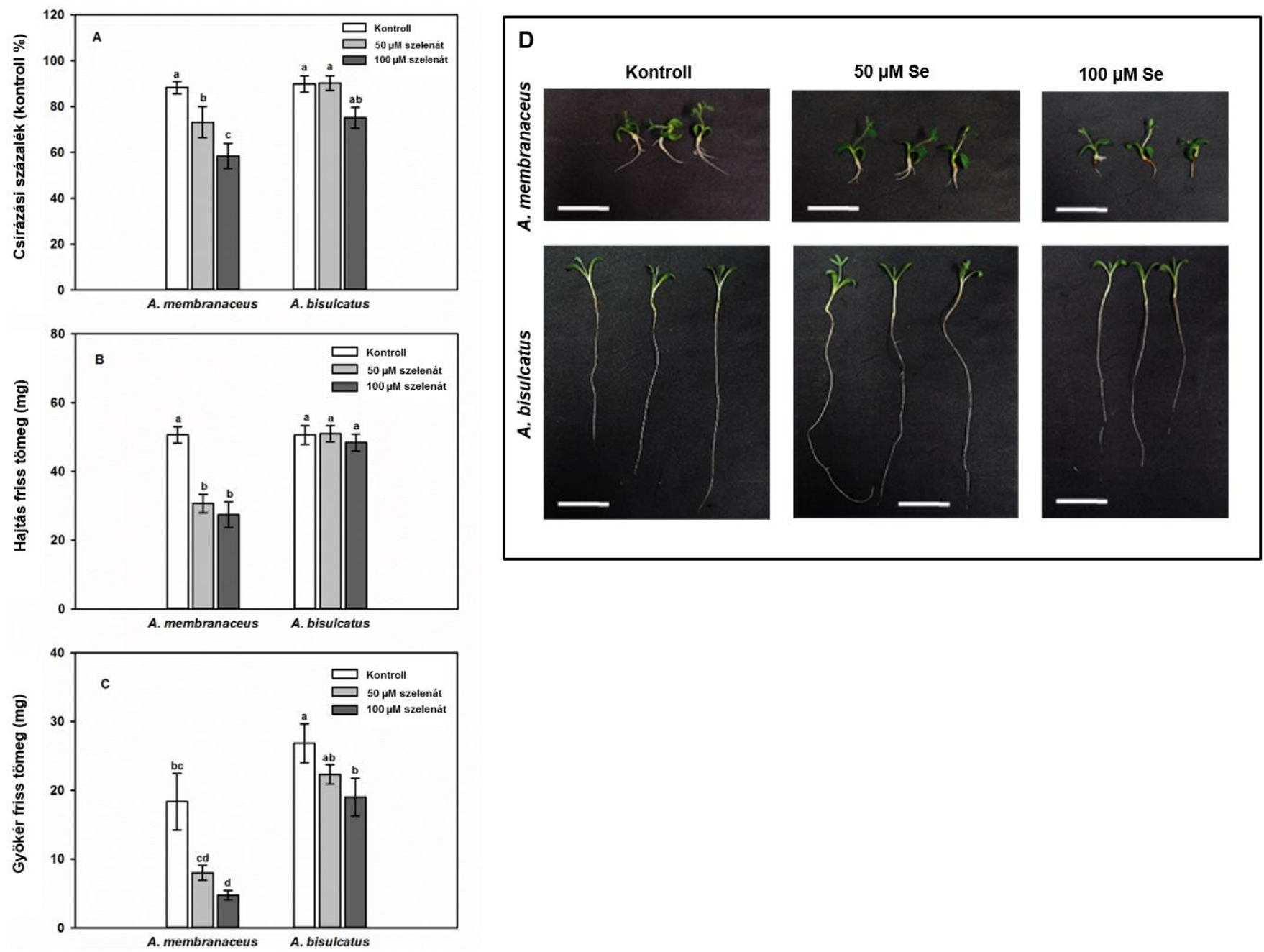

24. ábra A vizsgált Astragalus fajok csírázása (a), hajtás (b) és gyökér (c) friss tömege a 14 napos szelenátkezelés hatására. Az adatsorok összehasonlítása statisztikailag Duncan teszttel történt, ahol a szignifikáns különbségeket eltérő betükkel jelöltük ( $\mathrm{n}=15, \mathrm{P} \leq 0,05)$. (d) A 14 napos kontroll és szelenát-kezelt Astragalus membranaceus és Astragalus bisulcatus csíranövények morfológiáját bemutató reprezentatív felvételek (mérce $=3 \mathrm{~cm}$ ).

A növények szeléntürésére utaló toleranciaindex A. membranaceus-nál igen jelentősen csökkent minden kezelési koncentráció hatására, bizonyítva a növény szelénérzékenységét, míg a toleráns $A$. bisulcatus statisztikailag nem szignifikánsan, de a kontrollnál nagyobb értékeket mutatott (25. ábra a). A gyökérmerisztéma-sejtek életképessége jelentősen csökkent mindkét kezelési koncentráció hatására $A$. membranaceus-nál, míg a toleráns növényfaj csak a nagyobb dózisú szelenátkezelés hatására szenvedett szignifikáns csökkenést. Megemlítendő, hogy a két növényfaj azonos kezelési koncentrációjú adatsorai is különböznek statisztikailag szignifikáns módon, és mindkét kezelési koncentrációnál a toleráns faj mutatott magasabb életképességet (25. ábra b,c). 

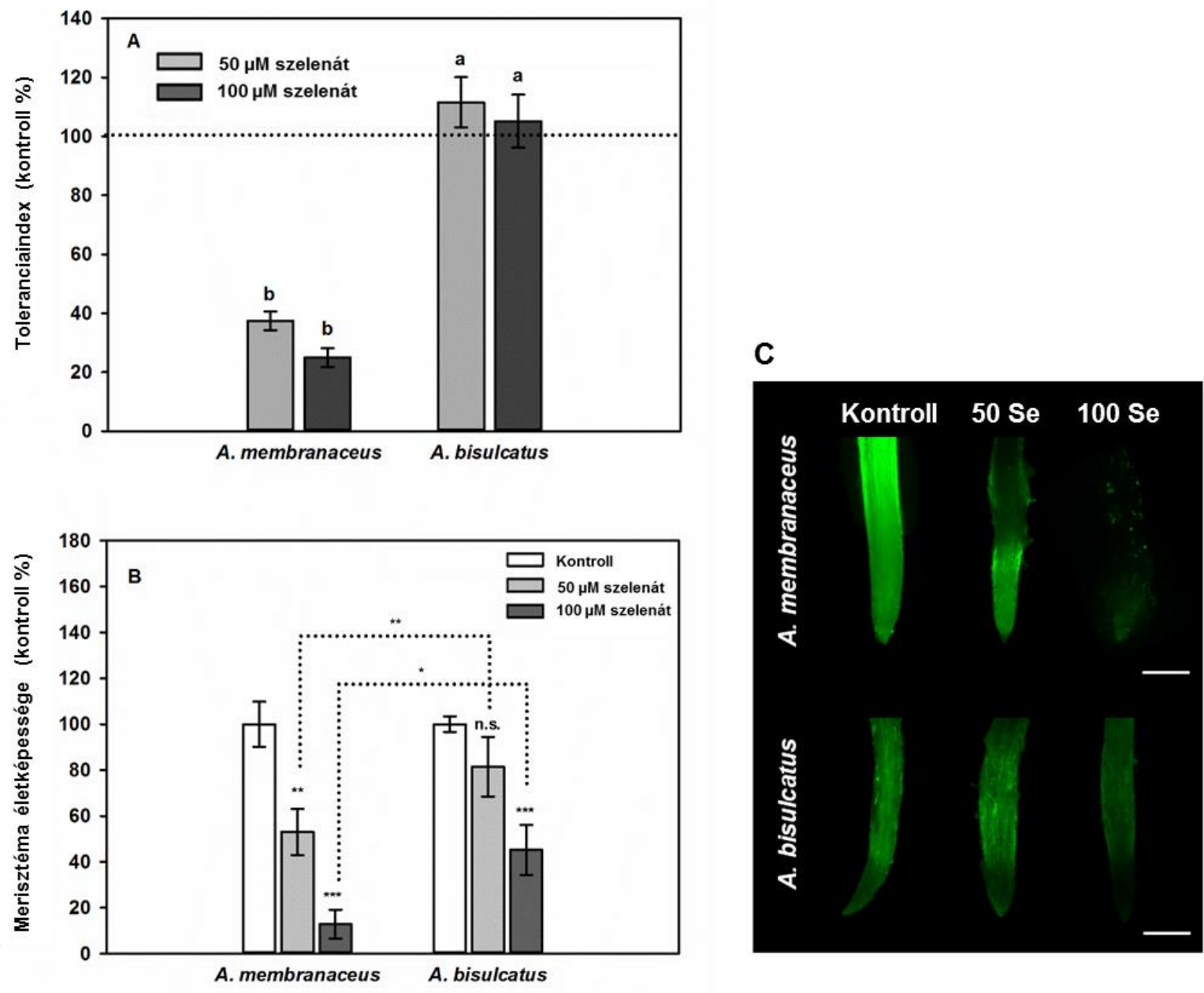

25. ábra A kontroll és szelén-kezelt Astragalus membranaceus és Astragalus bisulcatus szelén toleranciaindexe (a) mely a szelén-indukált főgyökér rövidülésből számolható. A különböző betük statisztikailag különböző adatsorokat jelölnek Duncan teszt alapján $(\mathrm{n}=10, \mathrm{P} \leq 0,05)$. A merisztémasejtek életképessége (kontroll \%, b) és reprezentatív fotók (c) az FDA-jelölt gyökércsúcsokról (mérce $=500 \mu \mathrm{m})$. Az adatsorok elemzése Student féle T-próbával történt, n.s.-el pedig a nem szignifikáns különbségeket jelöltünk ( $\mathrm{n}=15, * \mathrm{P} \leq 0,05, * * \mathrm{P} \leq 0,01, * * * \mathrm{P} \leq 0,001$,$) .$

A tapasztalt morfológiai és növekedési változások együtt járhatnak a gyökér szöveti szerkezetében és a sejtfalak összetételében beálló változásokkal. A gyökér átmérője az érzékeny fajnál nem változott a kezelések hatására, míg a toleráns fajnál a nagyobb kezelési koncentráció hatására gyökérvastagodást figyeltem meg (26. ábra a). A föbb régiók a gyökéren belül különbözőképp alakultak a két fajban. $50 \mu \mathrm{M}$-os kezelés hatására A. membranaceus-ban a kortex és sztéle vastagsága is megnőtt kontrollhoz képest, érdemes megfigyelni, hogy a gyökér összesített átmérőjét ez nem növelte meg annyira, hogy a teljes átmérő is szignifikánsan növekedjen, míg $100 \mu \mathrm{M}$-os kezelés hatására a kortex vastagsága enyhén növekedett a sztéle átmérője pedig szignifikánsan csökkent. A. bisulcatus-ban a kisebb kezelési koncentráció 
hatására a kortex vastagsága enyhén megnövekedett, míg a sztéle ezzel párhuzamosan kissé csökkent átméröben, míg a nagyobb kezelés mindkét gyökér régió vastagságának növekedését indukálta (26. ábra b,c). Az érzékenyebb faj sejtfalaiba jelentős mennyiségü kallóz rakódott be a szelénkezelések hatására, ezzel szemben a toleráns fajban ez statisztikailag szignifikáns módon csökkent a kontrollhoz képest (26. ábra d). A lignin és szuberin berakódása a sejtfalban szintén védelmi szerepet láthat el. Festéssel láthatóvá téve mindkét faj szállítóedényeiben volt jelentős mennyiségü lignin, valamint a kezelések hatására A. membranaceus-ban az exodermiszben, míg A. bisulcatus-ban az exo- és endodermiszben is jelentősen megnövekedett a lignin és szuberin mennyisége (26. ábra e).
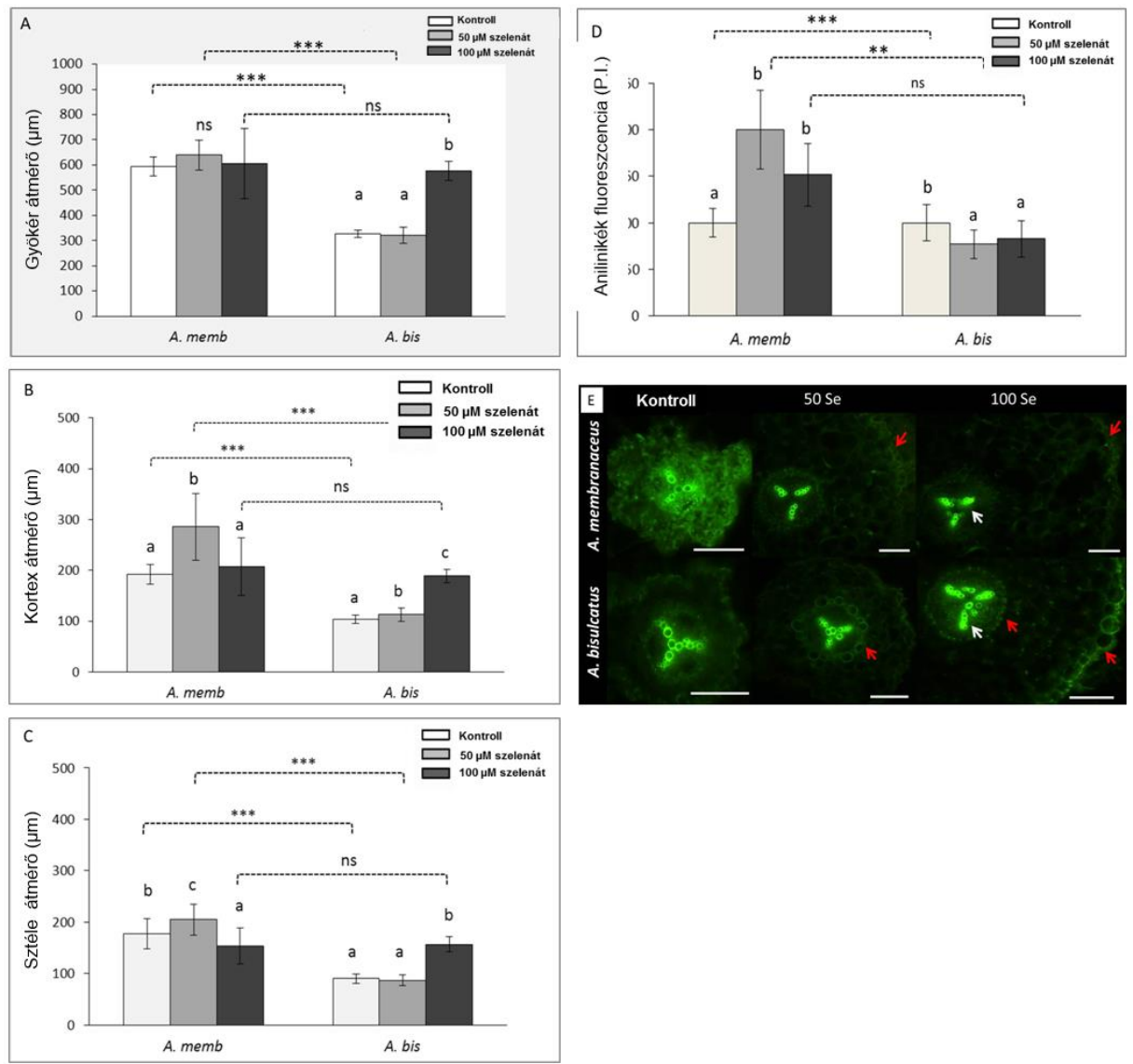

26. ábra Az Astragalus fajok (Astragalus membranaceus és Astragalaus bisulcatus) teljes gyökér- (a) és központi henger átmérője (c) valamint a kortex szélessége (b). A kallózberakódás anilinkék festékkel lett vizsgálva és kontroll százalékban került ábrázolásra (d). Az azonos fajon belüli adatsorok statisztikai különbségeit Kruskal-Wallis

ANOVA segítségével mutattunk ki $(\mathrm{n}=6, \mathrm{P} \leq 0,05)$, míg az azonos szelén koncentrációval kezelt, különböző növényfajok adatainak összehasonlítása Mann-Whitney U-teszttel történt $(\mathrm{n}=6, * \mathrm{P} \leq 0,05, * * \mathrm{P} \leq 0,01, * * * \mathrm{P} \leq 0,001$, n.s.- nem szignifikáns). A gyökerek lignin- és szuberinszintjének vizsgálata Auramin O festéssel történt (e), ahol a fehér nyilak xilém nyalábokat, míg a vörös nyilak az endo- vagy exodermiszt jelölik (mérce=100 $\mu \mathrm{m})$. 
A $\mathrm{O}_{2}{ }^{-}$mennyisége az érzékeny faj gyökerében és hajtásában is igen jelentősen megemelkedett a kontrollhoz képest, míg ezzel szemben a toleráns faj sziklevelei mutattak csak $\mathrm{O}_{2}{ }^{--}$-akkumulációt a legnagyobb kezelési koncentráció hatására (27. ábra a,b,c). A NAPDHoxidáz aktivitása mindkét növényfajban minden kezelés hatására megnövekedett a kontrollhoz képest, de megemlítendő, hogy új izoenzimek aktiválódása csupán az érzékeny faj gyökerére volt jellemző (27. ábra d). A SOD-aktivitás az érzékeny növényfajban mindkét szervben növekedést mutatott a kezelések hatására, ezzel ellentétben a hiperakkumuláló fajnál csupán a gyökérben láthattunk aktiválódást a kontrollhoz képest (27. ábra e,f). Az érzékenyebb faj szikleveleiben 6 különböző SOD izoformát detektáltunk (MnSOD I, Fe SOD I,II, Cu/Zn SOD I-III), melyek közül a kisebb kezelési koncentráció jelentősen megemelte öt izoforma aktivitását. Ezzel szemben a toleráns faj szikleveleiben két $\mathrm{Cu} / \mathrm{Zn}$ SOD izoforma aktivitását nem lehetett kimutatni, és a szelén hatására is csak enyhe aktivitás növekedést mutattak. A gyökérben A. membranaceus-nál és A. bisulcatus-nál is négy izoformát különböztethettünk meg, melyeknek emelkedett az aktivitása a kezelések hatására (27. ábra g). 

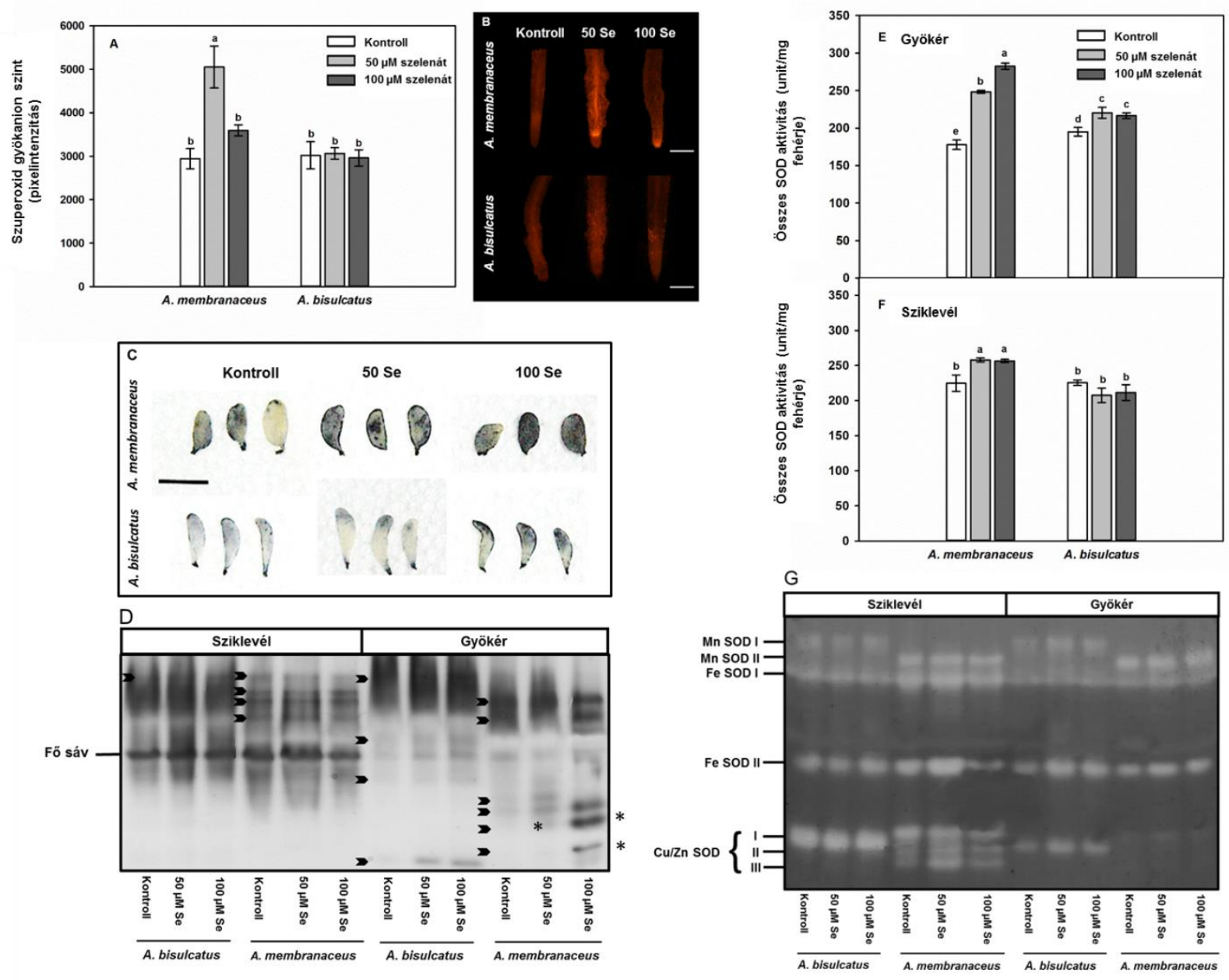

27. ábra A szuperoxid gyökanion metabolizmusa Astragalus fajokban 14 nap szelenátkezelés hatására. Szuperoxid gyökanion szint a gyökérben $(\mathrm{a}, \mathrm{b})$ DHE festéssel vizualizálva $(\mathrm{n}=10$, mérce $=500 \mu \mathrm{m})$, hajtásban $(\mathrm{c})$ NBT festéssel kimutatva, mely a molekulával reagálva kékes színné válik (mérce $=1 \mathrm{~cm}$ ). $\mathrm{A} \mathrm{O}_{2}{ }^{-}$keletkezésért felelős NADPHoxidáz enzim aktivitása natív gélben vizsgálva (d), ahol a fekete nyilak jelölik a különböző izoenzimeket, csillaggal kiemelve az újonnan megjelent izoenzimeket. A teljes SOD aktivitás gyökérben (e) és sziklevélben (f) ( $\mathrm{n}=3)$. Minden adatsort Duncan teszttel hasonlítottunk össze és a statisztikailag szignifikánsan különböző adatokat különböző betűkkel jelöltük $(\mathrm{P} \leq 0,05)$. A SOD enzim különböző izoenzimeinek aktivitása natív gélben $(\mathrm{g})$.

Az érzékenyebb A. membranaceus gyökerében és szikleveleiben is megnőtt a NO szint, ezzel szemben a toleráns növényfajban csupán a sziklevelekben volt kimutatható szelén-indukált növekedés (28. ábra a,b,c,d). A ONOO` tartalom a kisebb kezelési koncentráció hatására megnőtt az érzékeny növényfaj gyökerében, valamint mindkét szelénkoncentráció nagymértékben növelte a $\mathrm{ONOO}^{-}$szintet a sziklevélben. Ezzel szemben a toleráns A. bisulcatus gyökerében és hajtásában is inkább enyhén csökkent, vagy kontroll közeli $\mathrm{ONOO}^{-}$szintröl beszélhetünk (29. ábra a,b,c,d). A növények GSNO-szintje mind gyökérben, mind sziklevélben csökkent, kivéve az érzékeny 
növényfaj szikleveleit ahol koncentrációfüggő növekedést láthatunk (30. ábra a,b,c,d). A GSNOR enzim felelős a GSNO bontásáért, mely a toleráns növényfaj mindkét szervében csökkent aktivitást mutatott a szelenát hatására, míg az érzékeny gyökerekben kontroll közeli aktivitással rendelkezett. Érdemes megemlíteni, hogy $50 \mu \mathrm{M}$-os szelenát kezelés indukálta az enzimet $A$. membranaceus esetén a kontrollhoz képest (30. ábra e).
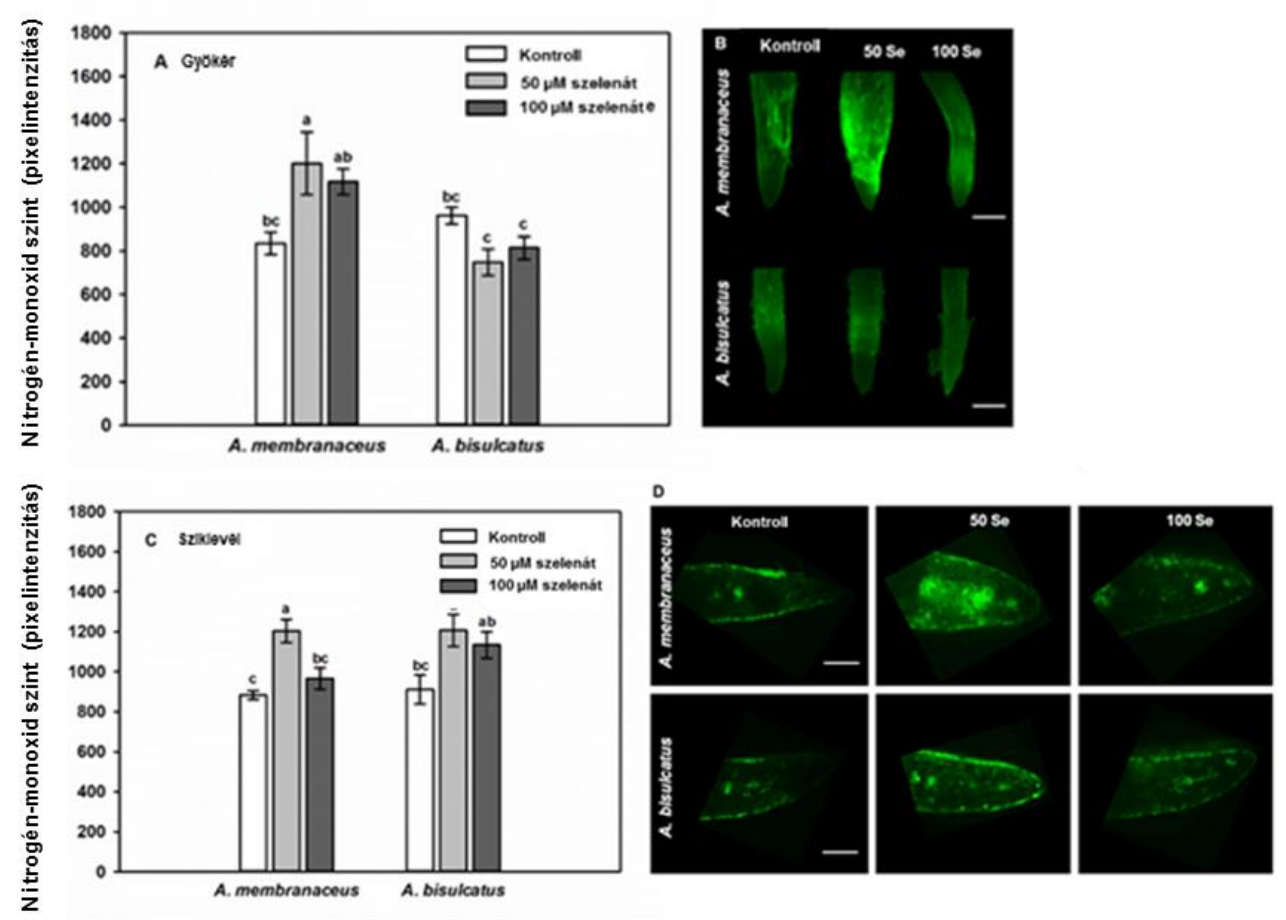

28. ábra A nitrogén-monoxidszint kontroll és szelenátkezelt Astragalus membranaceus és Astragalus bisulcatus gyökerében (a) és sziklevelében (c). Minden adatsort Duncan teszttel hasonlítottunk össze és a statisztikailag szignifikánsan különböző adatokat különböző betükkel jelöltem $(\mathrm{P} \leq 0,05)$. DAF-FM DA-val jelölt gyökércsúcsok (b) és sziklevél keresztmetszetek (d) (mérce $=500 \mu \mathrm{m})$. 


\section{B}
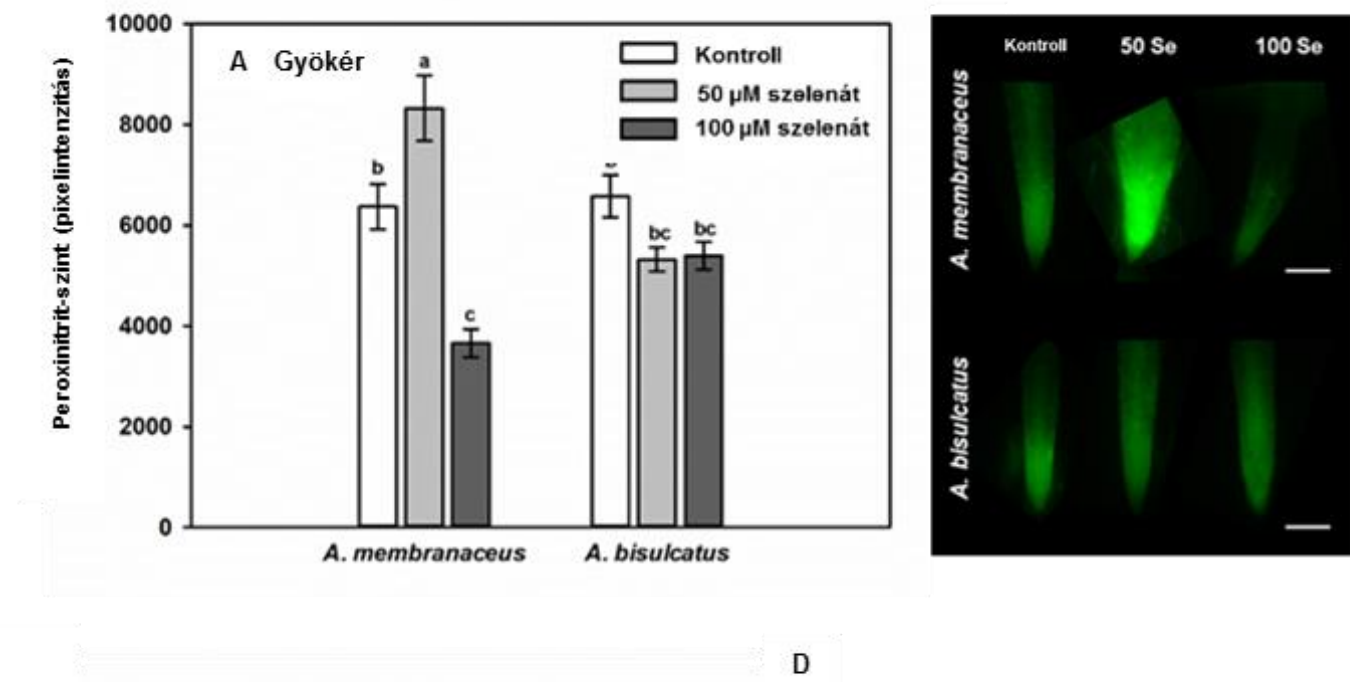

$$
\text { ह⿱艹 }
$$
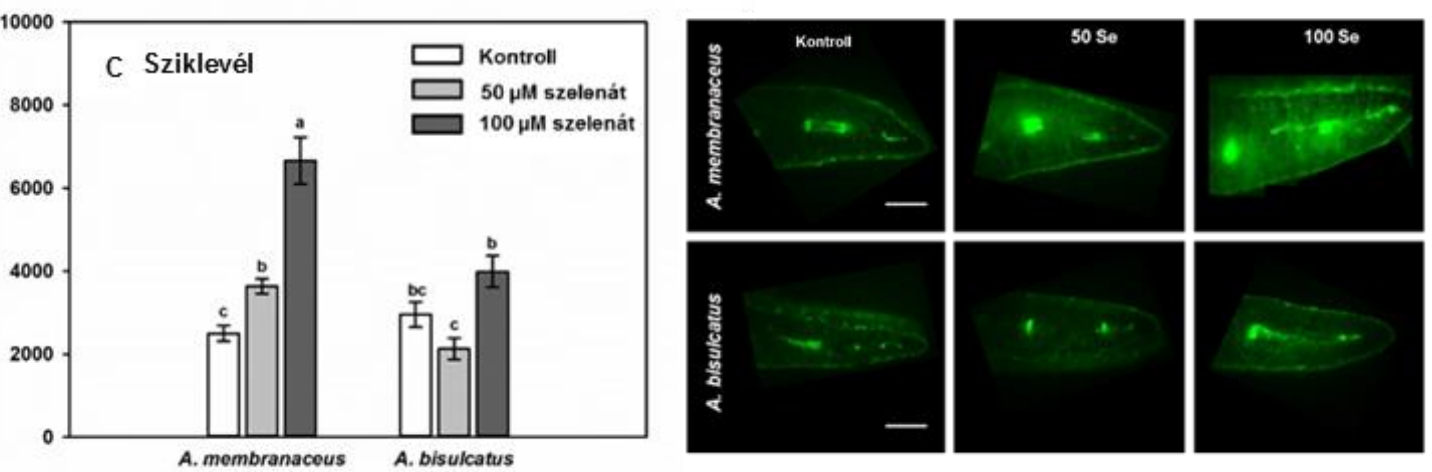

29. ábra Peroxinitrit-szint kontroll és szelenátkezelt Astragalus membranaceus és Astragalus bisulcatus gyökerében

(a.) és sziklevelében (c). Minden adatsort Duncan teszttel hasonlítottunk össze és a statisztikailag szignifikánsan különböző adatokat különböző betükkel jelöltük $(\mathrm{P} \leq 0,05)$. DHR fluorofórral jelölt gyökércsúcsok (b) és sziklevél keresztmetszetek $(\mathrm{d})($ mérce $=500 \mu \mathrm{m})$. 

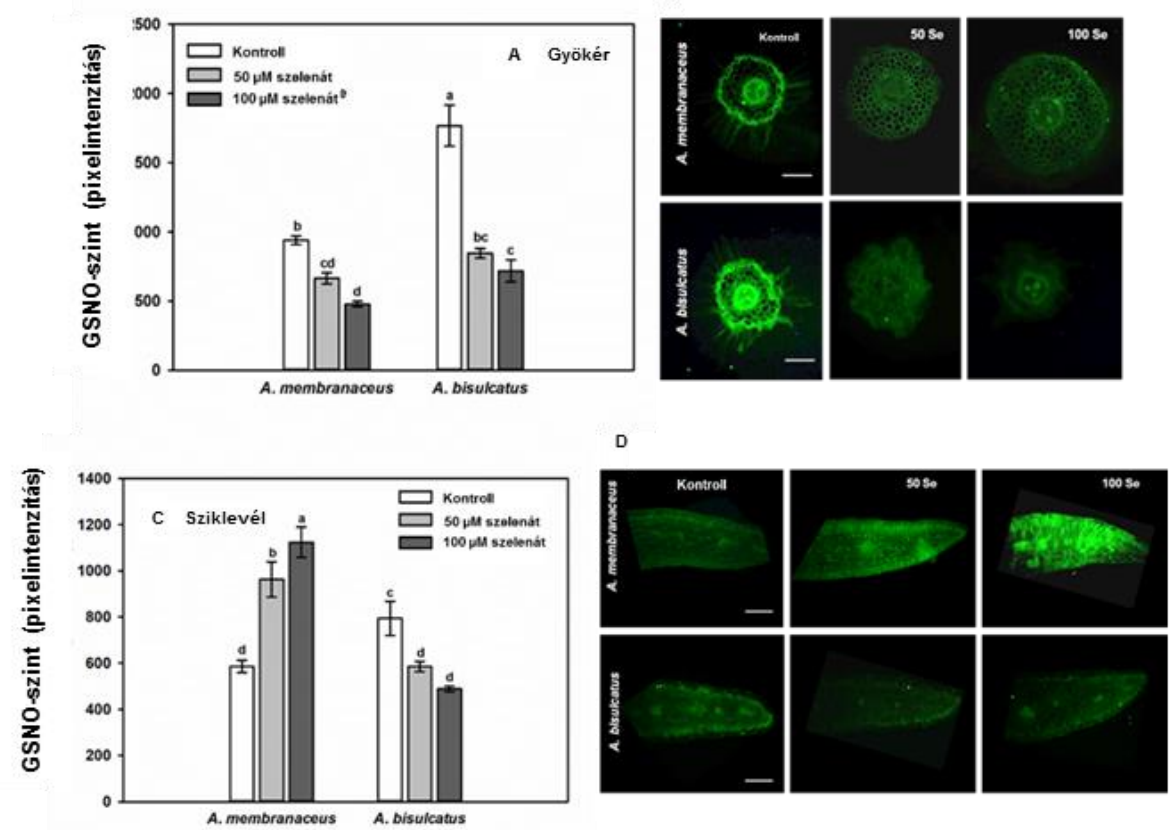

E
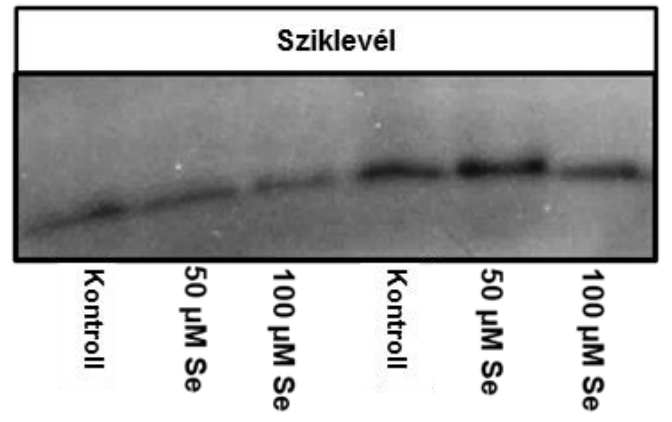

A. bisulcatus

A. membranaceus

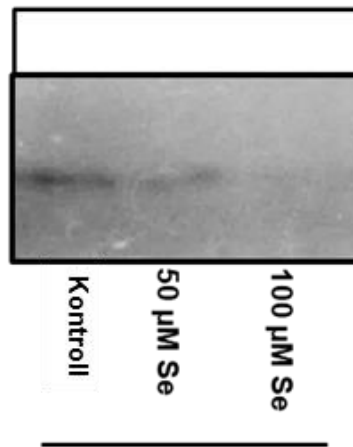

A. bisulcatus

\section{Gyökér}

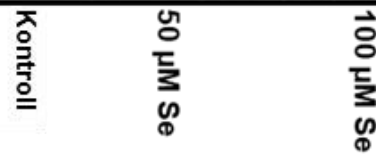

A. membranaceus

30. ábra A GSNO-szint kontroll és szelenát-kezelt Astragalus membranaceus és Astragalus bisulcatus gyökerében

(a) és sziklevelében (c). Minden pixel intenzitás érzéket Duncan teszttel hasonlítottunk össze a statisztika különbségek megállapításához, melyet különböző betűvel jelöltünk $(n=5-6, P \leq 0,05)$. Anti-GSNO immunjelölt gyökércsúcsok (b) és sziklevél keresztmetszetek (d) (mérce=200 $\mu \mathrm{m})$. (e) A GSNO-reduktáz enzim aktivitása natív gélben.

Immunfluoreszcenciával kimutatásra került a nitrált proteinek gyökéren belüli lokalizációja. Az érzékenyebb A. membranaceus esetén jelentős nitrációt láthatunk, mely gyökérben és hajtásban is intenzív minden szövetben, bár ki kell emelni a szállítónyalábok igen erős jelét mindkét szervben. Ezzel szemben a toleráns A. bisulcatus gyökerében látható csak intenzitásnövekedés a szelenátterhelés hatására, azon belül is a központi henger és exodermisz régiókban, míg a sziklevelek csökkent nitrációval rendelkeznek a kontrollhoz képest (31. ábra a,b,c,d). 

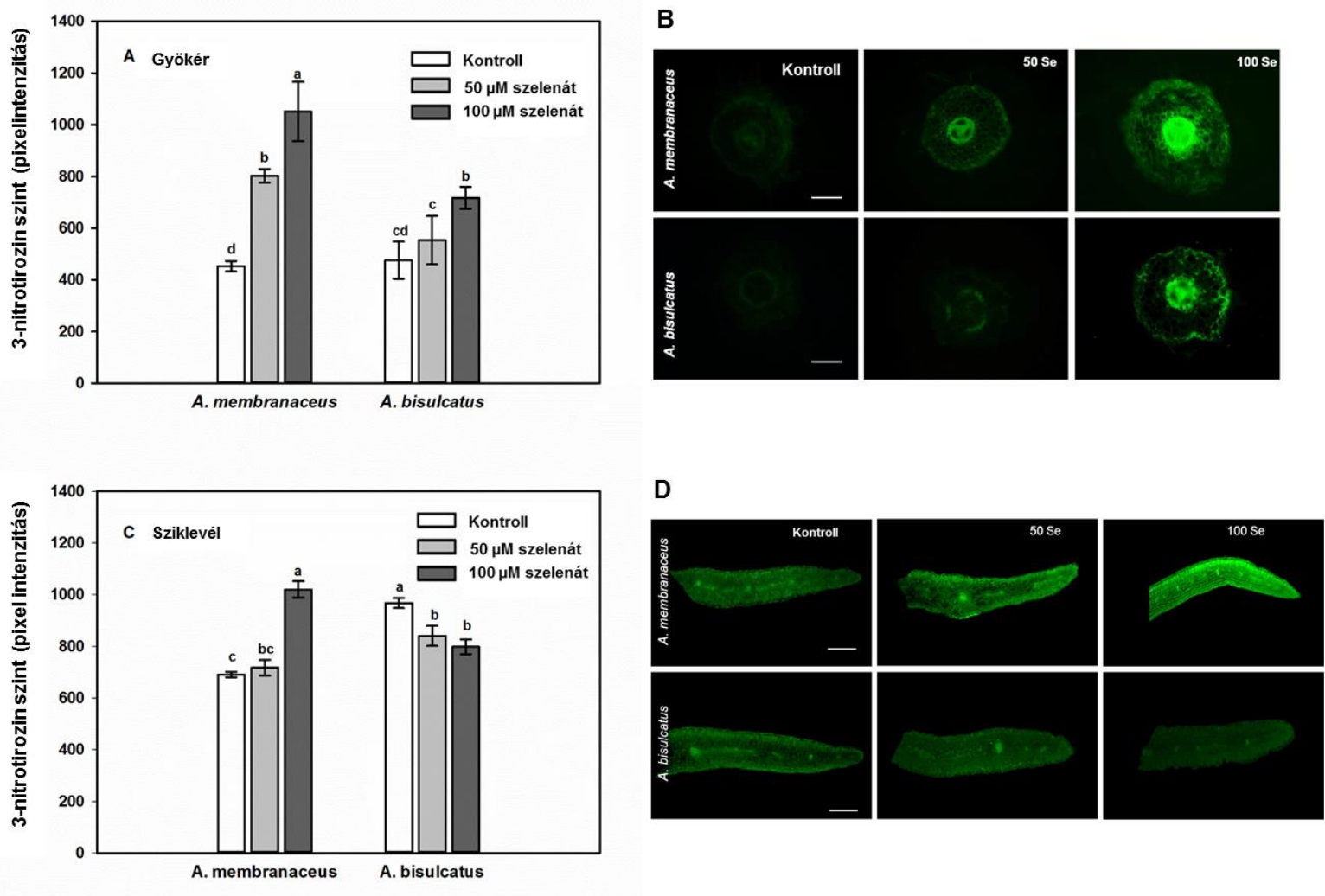

31. ábra In situ proteintirozin-nitráció gyökérben (a) és sziklevélben (c) 14 napig szelenáttalkezelt Astragalus membranaceus és Astragalus bisulcatus növények esetében. Az adatsorok összehasonlítására Duncan tesztet használtunk, a statisztikailag szignifikáns különbségeket pedig különböző betükkel jelöltük $(n=5-6, P \leq 0,05)$ A szöveti metszeteket bemutató példafotókon $(\mathrm{c}, \mathrm{d})$ is megfigyelhető a szállítónyalábok kitüntetett szerepe mindkét szervben.

Western blot analízissel tanulmányozható a növényi szervek nitrációs mintázata. Az érzékenyebb növényfaj esetében a sziklevélben öt jól elkülöníthető sávban, valamint összességében is megnő a nitrált proteinek mennyisége, míg ezzel szemben a toleráns növényfajban egy új nitrált fehérjesávtól eltekintve nincs jelentős változás. A gyökérben a toleráns növényfajban ismét enyhe változást tapasztalhatunk néhány csökkenő nitrációjú fehérjesáv képében, ezzel ellentétben az érzékeny növényfajban 2 sávnak erősödik a nitrációja, valamint több újonnan megjelenő fehérjesávot is láthatunk, mely jelentős nitrozatív stresszre utal (32. ábra). 

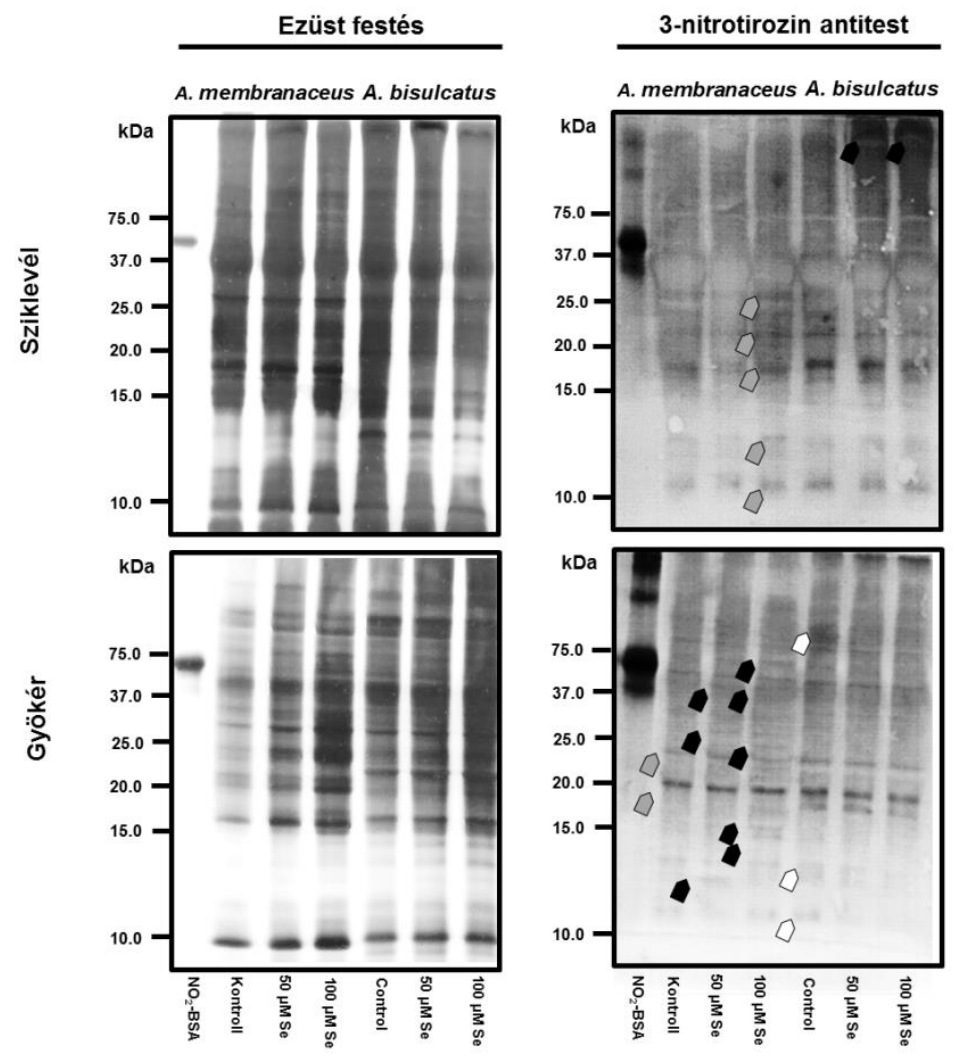

32. ábra Proteintirozin-nitráció kimutatása western blot analízissel 14 napig szelenáttal kezelt Astragalus membranaceus és Astragalus bisulcatus növényekben. A membránon az elöhíváskor fekete színü formazán keletkezik minden 3-nitrotirozin elleni antitesttel jelölt fehérjesávnál, amit a pozitív kontrollként alkalmazott nitrált borjú szérum albumin jól szemléltet. A szürke nyilak a kezelés hatására megnövekedő nitrációs intenzitású sávokat, a feketék újonnan megjelent sávokat, míg a fehérek csökkenő nitrációjú sávokat jelölnek. 


\section{VI. Értékelés}

\section{1. Különböző szelénformákat összehasonlító kísérletek}

Az irodalmi adatokhoz hasonlóan (Sharma és mtsai., 2010) az indiai mustár képes volt felvenni és felhalmozni szöveteiben a szelént mindkét szelénformával történő kezelés esetén. A szelén akkumulációja a gyökérben magas volt, míg a hajtásba történő transzlokáció gyér volt, hasonlóan a már leírt eredményekhez (Hawrylak-Nowak és mtsai., 2015). Az egyik lehetséges magyarázata a kismértékü transzportnak a szerves szelénformák keletkezésében keresendő. A szelenit könnyen beépül szerves molekulákba, melyek gyors keletkezése már jól dokumentált (de Souza és mtsai., 1998; Zayed és mtsai.,1998). A szelenát ezzel szemben jó transzlokációs értékekkel rendelkezett a hajtás irányába, mely enyhén csökkentette a gyökér szelénkoncentrációját, hasonlóan Ramos és mtsai. (2010) adataihoz.

A szeléntöbblet kihatott a növények biomassza-termelésére. A szelenátkezelés esetében a $20 \mu \mathrm{M}$-os koncentráció pozitív hatással bírt a növekedésre, mely az irodalom alapján valószínüleg a szelén stresszenyhítő tulajdonságainak tudható be (Djanaguiraman és mtsai., 2010; Garcia-Banuelos és mtsai., 2011; Kaur és mtsai., 2014; Hawrylak- Nowak és mtsai., 2015; Ebrahimi és mtsai., 2015; Hajiboland és Keivanafar, 2012). Pozitív hatást ellenben nem lehetett megfigyelni a szelenitkezelés esetében. A nagyobb kezelési koncentráció hajtás- és gyökérnövekedés-gátlása mindkét szelénformánál létrejött, de a szelenit toxikusabbnak bizonyult mind a hajtásban, mind a gyökérben, bizonyítva az irodalmilag is igazolt jelentősebb toxicitását (Hawrylak-Nowak és mtsai., 2015). A toleranciaindex és biomassza-csökkenés hátterében részben a gyökérmerisztéma életképességének csökkenése állt, mely hasonlóan az irodalmi adatokhoz (Smith és Watkinson, 1984) jelentősebben csökkent a toxikus szelenit hatására, mint a kevésbé toxikus szelenát kezelés esetében. A toxicitásbeli igen jelentős különbségek hátterében részben az áll, hogy a szelenit sokkal gyorsabban lép reakcióba aminosavakkal és épül be a fehérjékbe, mint a szelenát (Lyons és mtsai., 2005).

A növekedésen kívül a szelénkezelés hatással van a metabolizmusra, melyből kiemelten fontos a ROF- és RNF-metabolizmus esetünkben. Munkacsoportunk már igazolta a szeléntöbblet indukáló hatását a nitro-oxidatív stresszre (diszkutálva Kolbert és mtsai., 2016 által), melynek egyik központi molekulája a NO. A NO-szint emelkedését már dokumentálták szelénkezelés 
hatására borsóban (Lehotai és mtsai., 2016b) és mezei mustárban (Chen és mtsai., 2014), míg szelenitkezelés lúdfü gyökerekben nitrát-reduktáz-független NO csökkenést eredményezett (Lehotai és mtsai., 2016a). Kísérleteim folyamán az indiai mustárban egyik kezelés sem okozott jelentősebb NO szint változást, mely igazolja a NO metabolizmus fajszintü különbségeit szelénstressz esetében. A $\mathrm{O}_{2}{ }^{--}$mennyisége irodalmi adatok szerint emelkedik szeléntöbblet hatására (Tamaoki és mtsai., 2008; Freeman és mtsai., 2010), melyet a jelenlegi kísérleti rendszereinkben csupán a magasabb szelenitkezelés igazolt. A szelén egyik pozitív hatása, az antioxidáns kapacitás, jól megfigyelhető a $20 \mu \mathrm{M}$-os kezelési koncentráció esetében, melyet az irodalom is széleskörüen dokumentált (Xue és mtsai., 2001; Djanaguiraman és mtsai., 2010; Ekanayake és mtsai., 2015; Bachiega és mtsai., 2016). A ONOO-, mely a $\mathrm{O}_{2}{ }^{-*}$ és $\mathrm{NO}$ reakciójából keletkezik, igen erős makromolekula módosító hatással bír (Arasimowicz-Jelonek és FloryszakWieczorek, 2011), így mennyisége utal a nitro-oxidatív stressz erösségére. A szelenátkezelés hatására csökkent a mennyisége a gyökérmerisztémában, melynek hátterében az aktiválódó lebontó folyamatok állnak. A szelenit nagyobb koncentrációi emelték a $\mathrm{ONOO}^{-}$szintet, mely szintén igazolja a toxicitásbeli különbséget a két szelénforma között. A növényi fejlödés és abiotikus stressz rezisztencia egyik központi molekulája a glutation (Gill és mtsai., 2013). A szelén-indukált redukáltglutation-csökkenés széleskörủen leírt az irodalomban (Van Hoewyk és mtsai., 2008; Tamaoki és mtsai., 2008; Hugouvieux és mtsai., 2009; Freeman és mtsai., 2010; Dimkovikj és Van Hoewyk, 2014). A mustár esetében a szelenát egy enyhe csökkenést eredményezett csak, míg a szelenit jelentősen csökkentette a redukált glutation szintet. A szelenit képes reakcióba lépni a redukált glutationnal szeleno-diglutationt létrehozva, mely közben az oxidatív robbanáshoz hozzájáruló $\mathrm{O}_{2}{ }^{-}$gyökanion keletkezik (Wallenberg és mtsai., 2010). A proteintirozin-nitráció egyike a legáltalánosabb nitro-oxidatív makromolekula módosításoknak, mely fiziológiás körülmények között is jelen van (Corpas és mtsai., 2009; Chaki és mtsai., 2009, 2015). A növényi szervek között jelentős különbségek vannak a nitrációs mintázatban (Corpas és mtsai., 2009, Lehotai és mtsai., 2016a), mely a kísérletek folyamán is megfigyelhető volt. A szelenátkezelés enyhe nitrációsmintázat-erősödést okozott mindkét szervben, $\mathrm{s}$ bár ez hatással lehetett az aktív protein poolra, a növények számára kevésbé volt hátrányos. A szelenitkezelés ezzel ellentétben hajtásban megváltoztatta a növények nitrációs mintázatát (új nitrált fehérjesávok jelentek meg), mely hozzájárulhat e szelénforma jelentősebb toxicitásához. A gyökérben, bár a nitrációsmintázat nem változott, de a nitráció mértéke jelentősen emelkedett. A növényi proteinek 
inaktivációja nitráción keresztül egy igen érzékeny folyamat, így ennek jelentős változásai, akár a szelenit esetében, erős toxicitásra engednek következtetni.

\section{2. Különböző szelénérzékenységü növények összehasonlítása a keresztesvirágúak családjában}

A szelenitkezelés hatására mind a Brassica juncea, mind pedig az Arabidopsis thaliana felvette és akkumulálta szöveteiben a szelént, de ebben jelentős különbségek mutatkoztak a két faj között. Lúdfühajtásban a szelén mennyisége a kontroll kb. 28-szorosa, 125 szorosa és 300szorosa volt a 20, 50 és $100 \mu \mathrm{M}$-os kezelések esetén. Ez igen jelentős növekedés, mely gyökérben is jellemző volt, hiszen a kontroll gyökerek szelén tartalmának 70-szeres, 128-szoros és 220-szoros értékei alakultak ki ugyanezen kezelések hatására. Ezzel összehasonlítva, a fiatalabb mustárnövények a hajtásukban kisebb (19-szeres, 26-szoros és 68-szoros), gyökerükben pedig a lúdfüénél kissé magasabb (57-szeres, 133-szoros és 264-szeres) akkumulációs értékeket mutattak. A rossz transzlokáció mindkét fajban magyarázható a szelén aminosavakba, névlegesen szelenometioninba történő beépülésével (Zayed és mtsai., 1998). A felvett szelenit a legkisebb kezelési koncentráció esetében egyik növénynél sem okozott kontrolltól statisztikailag szignifikánsan eltérő biomassza-produkciót. Lúdfünél az 50 és $100 \mu \mathrm{M}$-os kezelések is jelentős friss és száraz tömeg csökkenést okoztak mind a hajtásban, mind a gyökérben, míg ezzel szemben az irodalom szerint (Zhang és mtsai., 2006; Harris és mtsai., 2014) toleránsabb növényfaj csupán a nagyobb kezelés hatására mutatott számottevő csökkenést. A főgyökérhossz 50\%-os csökkenéséhez $120 \mu \mathrm{g} / \mathrm{g}$ száraz tömeg szelén kellett lúdfünél, míg az indiai mustár, bizonyítva toleranciáját, $250 \mu \mathrm{g} / \mathrm{g}$ száraz tömeg mellett mutatta ugyanezt a választ. A gyökérmorfológia is megváltozott. Az Arabidopsis gyökerei $20 \mu \mathrm{M}$ kezelés hatására több oldalgyökeret növesztettek, ellensúlyozva a kissé csökkent fögyökérhosszt, míg a nagyobb dózisú kezelések hatására az oldalgyökérszám és főgyökérhossz is jelentősen csökkent. A magyarázat erre a gyökérmerisztéma életképességében keresendő, hiszen minden kezelés jelentősen csökkentette azt, bizonyítva a növény érzékenységét a szelénstresszel szemben, melyet más munkák is dokumentáltak már (Lehotai és mtsai., 2016a). A mustár főgyökérhossza megnőtt a kontrollhoz képest a $20 \mu \mathrm{M}$ szelenit hatására, melyhez a kontrollhoz viszonyítva változatlan 
életképesség tartozott, alátámasztva a szelenit pozitív hatását kis mennyiségben. A főgyökérhossz csökkenését csupán a $100 \mu \mathrm{M}$-os kezelés esetén figyeltük meg, de mindkét magasabb kezelési koncentráció növelte az oldalgyökerek számát, a növény így próbálta tolerálni a szelénstresszt (Zhang és mtsai., 2007; Tamaoki és mtsai., 2008; Freeman és mtsai., 2010). A főgyökér merisztémájának életképessége jelentősen csupán a két nagyobb kezelési koncentráció hatására csökkent, de a redukció mértéke elmaradt a lúdfü életképesség-csökkenésétöl. A növekedési adatok és a merisztéma-életképesség jelentősen csökkent a növényekben a szelenitkezelés hatására, s jól példázza a két faj közötti relatív toleranciakülönbséget (Schiavon és Pilon-Smits, 2017).

A fajok közötti szeléntolerancia különbségében az eltérő szövet- és sejtszintü detoxifikációs mechanizmusok lehetnek felelősek. A szelénvolatilizáció bizonyított a keresztesvirágúak családjában, $\mathrm{s}$ az indiai mustár képes $60 \mu \mathrm{g} / \mathrm{g}$ friss tömeg szelén volatilizására naponta $40 \mu \mathrm{M}$ szelenitkezelés hatására (Van Huysen és mtsai., 2003). Ez a jó hatékonyságú volatilizációs képesség a kísérleteimben is igazolható volt a 20 és $100 \mu \mathrm{M}$ kezelések hatására megnövekedő sztómaszámmal és nyitottsággal. Az érzékenyebbnek bizonyuló modellnövény bár fokozta a gázcserenyílások nyitottságát, de a számuk jelentősen csökkent, így az összesített sztómakonduktancia feltehetőleg nem változott sokat. Az irodalomban található adatok szerint is növényfaj-függő a volatilizációs képesség, hiszen szelénkezelés hatására a sztómakonduktancia megnőtt dohányban (Jiang és mtsai., 2015) és takarmánylucernában (Hajiboland és mtsai., 2015), míg csökkent uborkában (Haghigi és mtsai., 2016) és kukoricában (Jiang és mtsai., 2017). Terry és mtsai. (1992) kimutatták, hogy a levél szeléntartalma és a volatilizáció között kapcsolat van, de a szerves szelénformák hatásmechanizmusa a sztómamozgásra mindmáig ismeretlen. A hajtás szeléntárolásában szerepet játszanak az epidermiszben lévő raktározó sejtek (Freeman és mtsai., 2006, 2010), melyekben a kísérletemben antociánakkumulációt tapasztaltam. Az irodalom szintén beszámol antociánfelhalmozódásról (Hawrylak-Nowak, 2008; Liu és mtsai., 2017), de a háttérben két folyamat is lehet: az antociánmolekulák képesek fémek vagy a szelén megkötésére, így védelmi szerepük lehet (Winkel-Shirley, 2002). A másik magyarázat pedig az, hogy a szelén megzavarja a foszfor metabolizmusát a növényeken belül (Li és mtsai., 2008), melynek hiánya antociánfelhalmozódással, így lilulással jár. A másik jelentős szeléndetoxifikálási út a sejtfalban történő megkötés és kompartmentalizáció. A sejtfalak pektintartalma képes fémek megkötésére, így megelőzve a citoplazmába jutásukat (Polec-Powlak és mtsai., 2007; Douchiche és mtsai., 
2010; Hossain és mtsai., 2006). Az érzékenyebb lúdfüben a pektintartalom csupán egyetlen kezelésnél növekedett meg, míg ezzel szemben a toleráns növényfaj mindhárom kezelésnél jelentösebb növekedést mutatott, mely alátámasztja a pektin nehézfémek és nemfémek elleni toleranciában betöltött szerepét (El-Moneim és mtsai., 2014). Érzékeny növényfajokban dokumentálták a nehézfémek hatására akkumulálódó kallózt a gyökerekben (Llugany és mtsai., 1994; Piršelová és mtsai., 2012), melyhez hasonlóan a lúdfü is jelentős kallózmennyiséget halmozott fel. A kallóz megvastagítva a sejtfalat képes gátolni a fémek citoplazmába jutását (Kartusch, 2003), de akkumulációja gátolhatja a plazmodezmák müködését megzavarva a sejtek közötti kommunikációt, így hozzájárulva a növekedésgátláshoz (Zavaliev és mtsai., 2011).

A szeléntöbblet prooxidánsként viselkedhet és felboríthatja a ROF természetes metabolizmusát (Van Hoewyk, 2013). Kísérleteink során mind a $\mathrm{O}_{2}-$-szint, mind a $\mathrm{H}_{2} \mathrm{O}_{2}$-szint jelentősen változott a két növényfajban, kiváltképp a $100 \mu \mathrm{M}$-os kezelési koncentráció hatására. Az irodalmi adatoknak ezek megfelelnek, hiszen különbözö növényfajokban és szervekben leírták már ezt a folyamatot (Tamaoki és mtsai., 2008; Freeman és mtsai., 2010; Lehotai és mtsai., 2012, 2016a, 2016b; Chen és mtsai., 2014; Dimkovikj és Van Hoewyk, 2014). Az egyik legföbb antioxidáns, a glutation mennyisége is megváltozott a kezelések hatására, mely az irodalomban is jól dokumentált (Tamaoki és mtsai., 2008; Freeman és mtsai., 2010; Lehotai és mtsai., 2011; Dimkovikj és Van Hoewyk, 2014). Az előzőekben leírt reakció, miszerint a szelénnel szeleno-diglutationt (Terry és mtsai., 2000; Schiavon és Pilon-Smits, 2017) alkot, itt is fontos szerepet játszhat, kiváltképp hogy a redukáltglutation-csökkenés jellemzőbb a toleráns fajra. A sejtfali peroxidázok szerepe sokrétü, de legtöbbször a sejtfali oxidációs reakciókért felelősek. A toleráns mustár minden kezelés hatására aktiválta a sejtfal-asszociált peroxidázokat, ezzel szemben az érzékeny növényfajban csak a két nagyobb dózis okozott változást. Az általuk szintetizált hosszú szerves fenolok hozzájárulnak a sejtfal rigiditásához (Cosgrove, 1997), mely részben felelös lehet a gyökérnövekedés gátlásáért. A lipidperoxidáció az egyik legelfogadottabb markere az oxidatív stressznek (Pompella és mtsai., 1987), amely során az ROF-k károsítják a membránok többszörösen telítetlen zsírsav-oldalláncait, reaktív aldehideket eredményezve (Hartley és mtsai., 1999). A specifikus festés alapján kijelenthető, hogy a lúdfüben már a kisebb koncentrációjú kezelések is jelentős oxidatív stresszt eredményeztek, míg a toleráns növényfajban csak a legnagyobb kezelési dózis okozott lipidperoxidációt a gyökerekben. 
A ROF mellett a szeléntöbblet hatással van az RNF metabolizmusra is. A NO-szint növényfajonként eltérően alakul szelénterhelés hatására, mivel a borsó és mezei mustár növényekben növekvő mennyiséget mutattak ki (Lehotai és mtsai., 2016b; Chen és mtsai., 2014), míg a lúdfü csíranövényeknél lecsökkent a molekula szintje (Lehotai és mtsai., 2016a). A lúdfüben a két kisebb kezelési koncentráció az irodalom alapján várt eredményt adta, míg a toleráns növényfajban nem változott jelentősen az NO-szintje. A csökkenés hátterében Lehotai és mtsai. (2016a) szerint feltehetően a citokininakkumuláció állhat, de kísérleteink során ezt nem vizsgáltuk. A $\mathrm{ONOO}^{-}$-szint megemelkedett mindkét faj gyökerében, de érdemes megemlíteni, hogy a kontrollhoz viszonyított növekedés jelentösebb volt az érzékeny növényfajban, így feltételezhető, hogy a toxicitási mechanizmusok közé tartozik. A ONOO- PTN-t okoz, mely bár mindkét növényfajban létrejött, a toleránsabb mustárnövények jelentősebb nitrációsmintázaterősödést szenvedtek el, mint a lúdfü. Mivel a nitrozatív stressz sok egyéb makromolekulamódosítást is magába foglal, valamint a nitrációval inaktivált fehérjék sem ismertek esetünkben, így adataink alapján kijelenthető, hogy a nitráció, bár kapcsolódik a szelénstresszhez, de a szelén toxicitásáért nem önállóan felelős.

\section{3. Különböző szelénérzékenységü növények összehasonlítása csüdfüvek családjában}

Az Astragalus membranaceus és az Astragalus bisulcatus is képes volt nagymennyiségü szelén akkumulációjára, de a szerveik közti arányok jelentősen eltértek. Az A. membranaceus szikleveleiben bár megnőtt a szelén mennyisége minden alkalmazott szelenátkezelés hatására, de az A. bisulcatus szikleveleiben az akkumuláció több, mint hétszerese volt a másik fajnak. Az $A$. bisulcatus szelén-hiperakkumuláló tulajdonsága így kíséreteinkben is bizonyítást nyert, kiváltképp, ha megfigyeljük az igen jónak mondható 3,8-szoros hajtás/gyökér szelén-arányt (Freeman és mtsai., 2010). Az A. bisulcatus alap szeléntartalma is magasabb volt a kínai csüdfühöz képest, valamint a sziklevelekben felhalmozott $1800 \mu \mathrm{g} / \mathrm{g}$ száraz tömeg is alátámasztja a növény szelén-hiperakkumulációját (Mehdawi és Pilon-Smits, 2012). A nagymennyiségű szelén felborítja más nyomelemek homeosztázisát (Pazurkiewicz-Kocot és mtsai., 2003; Filek és mtsai., 2010; Zembala és mtsai., 2010), mely itt is megtörtént. Az érzékenyebbnek bizonyuló növényfajban a $\mathrm{Mn}, \mathrm{Fe}, \mathrm{Zn}$ és B koncentrációja is csökkent a kontrollhoz képest, míg ilyet a toleráns növényfajban nem tapasztalhatunk. A felvett szelén csökkentette az A. membranaceus 
csírázását, főgyökérmegnyúlását és gyökér biomassza-termelését koncentráció-függő módon, mely hasonló az irodalmi adatokhoz (Tamaoki és mtsai., 2008). A csökkent fögyökérhossz és biomassza-produkció hátterében részben egy jelentősen csökkent gyökérmerisztéma-életképesség áll, mely alátámasztja a növény jelentős szelén-érzékenységét. Ezzel ellentétben az A. bisulcatus csupán a $100 \mu \mathrm{M}$-os kezelés hatására szenvedett enyhe gyökérbiomassza- és merisztémaéletképesség csökkenést, de ezek messze elmaradtak az érzékeny növényfaj válaszaitól. Az eredményeink is alátámasztják, hogy a hiperakkumuláló növényfajok jelentős toleranciával rendelkeznek, de ez nem a felvett elem kizárásán alapul (Mehdawi és Pilon-Smits, 2012). Az A. bisulcatus esetében, a szelenocisztein-metiltranszferáz (SMT) enzim igen jelentősen hozzájárul a toleranciához, mivel képes annak megelőzésére, hogy a keletkező szelenocisztein fehérjékbe épüljön be (Neuhierl és Bock, 1996). Irodalmi adatok alapján a fémek akkumulációja kihat a gyökerek vastagságára (Arduini és mtsai., 1995; Maksimović és mtsai., 2007; Potters és mtsai., 2007). Az érzékeny növényfaj gyökere vastagabb volt, mint a toleráns növényé, melyet részben a vastagabb kortex magyaráz. Az A. bisulcatus a $100 \mu \mathrm{M}$-os kezelés hatására megnövelte mind a kortex mind a sztéle vastagságát, s ezt a toleranciamechanizmust már megfigyelték más hiperakkumuláló növényeknél is (Li és mtsai., 2009). A sejtfalösszetétel megváltozása klasszikus stresszválasz nehézfémstressz esetében, ilyen a kallózszintézis (Kartusch, 2003; Feigl és mtsai., 2013) vagy az exodermális szuberinberakódás (Dalla Vecchia és mtsai., 1999; Rahoui és mtsai., 2017). Az érzékeny növényfaj a sejtfalaiban mindkét sejtfalelváltozást mutatta, míg ezzel szemben kallózszint-növekedést nem lehetett megfigyelni a hiperakkumuláló növényeknél. Érdemes azonban megemlíteni, hogy az A. bisulcatus nem csupán az exodermiszben, hanem az endodermiszben is jelentős szuberint halmozott fel a kezelések hatására, mely hozzájárulhat a szeléntoleranciához (Vaculík és mtsai., 2012).

Az oxidatív stressz előidézése egyike a szelén toxicitási mechanizmusainak (Van Hoewyk, 2013), s az irodalom számos helyen dokumentálta a módosult $\mathrm{O}_{2}{ }^{-}$-szintet (Tamaoki és mtsai., 2008; Freeman és mtsai., 2010; Chen és mtsai., 2014; Dimkovikj és Van Hoewyk, 2014), mely az érzékeny $A$. membranaceusnál is megfigyelhetö. A növényben a szelénkezelés megnövelte a NADPH-oxidáz enzimek aktivitását, kiváltképp gyökérben, ahol új izoenzimeket is megfigyeltünk. A SOD aktivitása minden izoformában s mindkét szervben nőtt a kontrollhoz képest, de ez nem volt képes megakadályozni az oxidatív robbanást. Más hiperakkumulálókban leírták már az antioxidáns védelmi rendszer fontosságát (Freeman és mtsai., 2010) az oxidatív 
stressz elleni védekezésben, s a mi eredményeink is alátámasztják ezt. A hiperakkumuláló $A$. bisulcatus-ban legtöbbször kontrollközeli maradt a $\mathrm{O}_{2}{ }^{-}$-szint. A NADPH-oxidázok aktiválódtak, de ezzel párhuzamosan a $\mathrm{Cu} / \mathrm{Zn}$ SOD aktivitása is megnövekedett, mely ezt képes volt lebontani a $\mathrm{O}_{2}{ }^{-}-\mathrm{t}$, megvédve a sejteket az oxidatív károsodásoktól, valamint nem szabad elfeledni, hogy a hiperakkumulálók szerves szelénformákként tárolják a szelént, így csökkentve a hatását az oxidatív folyamatokra (Schiavon és Pilon-Smits, 2017). Számos publikáció bemutatta már a szelénérzékeny növényfajok NO-szintjének növekedését (Lehotai és mtsai., 2016b; Chen és mtsai., 2014), mely szintén megfigyelhető az kísérleteinkben $50 \mu \mathrm{M}$ szelenátkezelés hatására. A NO-termelés növekedéséért részben a nitrát-reduktázt teszik felelőssé, mely föleg gyökérben, de kisebb mértékben hajtásban is szerepet játszik az NO szintézisben (Zhang és mtsai., 2016). A szelén-indukált NR aktivitásnövekedést már feltételezték (Rios és mtsai., 2010), s ennek hátterében a molibdénkoncentráció növekedése állhat (Shinmachi és mtsai., 2010; Yu és mtsai., 2010), mely esetünkben is megfigyelhető volt. A nitro-oxidatív stressz súlyosságát jól tükrözi a $\mathrm{ONOO}^{-}$molekula szintje (Arasimowicz-Jelonek és Floryszak-Wieczorek, 2011), mely az esetünkben az érzékeny növényfajnál emelkedik csupán meg a szelenát hatására. A $100 \mu \mathrm{M}$-os kezelés hatására gyökérben megfigyelhető hirtelen $\mathrm{ONOO}^{-}$-szint-csökkenést valószínüleg egy aktiválódó lebontó mechanizmus okozhatja. A GSNO mennyiségét növényi szövetekben három folyamat befolyásolja: spontán NO-felszabadítás, GSNOR által katalizált redukció és transznitroziláció más proteinekkel (Begara-Morales és mtsai., 2018; Lindermayr, 2018). Az érzékeny növényfaj gyökerében csökkent a GSNO mennyisége, amiért a GSNOR aktivitás lehet felelős, míg ezzel szemben a jelentős GSNOR aktivitás sem volt képes lebontani a termelődő GSNO mennyiséget a sziklevelekben. A. bisulcatus esetében mindkét szervben csökkent a GSNO mennyisége, de a csökkenő GSNOR aktivitás helyett inkább a transznitrozilációs folyamatok erősödését feltételezhetjük. Sziklevelekben az NO-szint kisebb emelkedése inkább a spontán NO felszabadítási reakciók lejátszódására utal. A proteintirozin-nitráció mindkét növényben jelen volt kontroll körülmények között, s a kezelések hatására A. membranaceus-ban jelentősen megnövekedett mindkét szervben. Megemlítendő, hogy a gyökérben újonnan megjelent nitrált proteinsávok igen erős stresszre engednek következtetni, hiszen az aktív proteinpool jelentős változását mutatják. A toleráns növényfaj fiziológiás nitroproteomja kezelés hatására a gyökérben eltünő sávokat eredményezett, melyet feltételezhetően a nitrált proteinek proteoszómális lebontása okozott (Castillo és mtsai., 2015). A toleráns növényfaj 
kontrollkörülmények között jelentősebb GSNO-tartalommal és nitroproteommal rendelkezett, mint az érzékeny növényfaj, így feltételezhető, hogy ezek jobb szabályozása hozzájárulhat a szeléntoleranciájához.

\section{4. Összesített konklúzió}

Az irodalom széleskörüen foglalkozott már a szelénstressz hatásával és az ezek mögött álló molekuláris háttérfolyamatokkal, de a másodlagosan jelentkező nitro-oxidatív stressz és RNF molekulák metabolizmusa kevéssé vizsgált, kapcsolatuk a szeléntoleranciával alig ismert. Az eredményeink megerösítik az irodalmi adatokat, miszerint a szelén felvétele és hajtásba történő transzlokációja mindhárom, általunk alkalmazott kísérleti rendszerben megtörténik, bár mértéke a szelénformáktól és a növényfajtól függően különbségeket mutat. A különbségek a két toleránsnak mondható növényfaj, a Brassica juncea és az Astragalus bisulcatus összehasonlításakor még egyértelmübbek, hiszen a toleráns indiai mustár a hajtásába kevés szelént akkumulál, míg ezzel szemben a toleráns hiperakkumuláló A. bisulcatus inkább a szikleveleibe transzportálja a szelént. Eredményeink az irodalommal egybehangzóan arra utalnak, hogy a növekedési paraméterek és a gyökérmerisztéma életképessége a szelénérzékenységgel szorosan összefügg. Elsőként figyeltük meg, ezért új eredménynek számít, hogy a különböző detoxifikációs tolerancia mechanizmusok közül a sejtfalban gyorsan szintetizálható kallózfelhalmozódás jellemző az érzékeny Arabidopsis thaliana-ra és A. membranaceus-ra, míg a toleráns Brassica juncea és Astragalus bisulcatus inkább pektint és szuberint építenek be a sejtfalba, valamint a volatilizáció is inkább itt volt megfigyelhetö. Mivel ismert a kallózbeépülés szimplasztikus transzportot, ezáltal pedig növekedést gátló hatása, elképzelhető, hogy az érzékeny fajokban a kallóz megjelenése részben oka lehet a jelentős növekedésgátlásnak. A nehézfémmegkötő kapacitással rendelkező pektin és szuberin felhalmozódása a szeléntoleranciával függhet össze. A rendelkezésre álló irodalomi adatokat megerősítik az eredményeink, miszerint a súlyosabb oxidatív stressz a szeléntoxicitás egyik hatásmechanizmusa. Az irodalom kevésbé vizsgálta az RNF formák metabolizmusát, így a kutatás során a szeléntolerancia és nitrozatív stressz közötti összefüggéseket kerestük, és ezzel kapcsolatos eredményeink a nemzetközi irodalomban újnak számítanak. A NO, mivel sok 
intracelluláris folyamat befolyásolja a szintjét összességében inkább fajfüggő választ mutat, s a szintjében bekövetkező szelén-indukált változásokat nem lehet közvetlenül a toleranciához kötni. A peroxinitrit ellenben, mely a nitro-oxidatív stressz egyik legfőbb molekulája, a toxikus szelénkoncentrációk hatására akkumulálódott a növényekben, így ez a molekula szorosan kapcsolható a szeléntoxicitáshoz. A belöle kiinduló PTN kapcsolata a szelénstresszel így kiemelten fontos. A kezelés hatására újonnan megjelenő nitrált fehérjesávok a szelénérzékeny, erős stressznek kitett növényekben detektálhatóak, melynek következménye feltehetően a fehérjék inaktivációja. Ezzel szemben a toleráns növényekben megfigyelt csökkenő nitrációjú fehérjesávok proteinlebontó folyamatok aktiválódását feltételezik, melyek akár a szelenoproteineket is detoxifikálhatják, így elősegítve a szeléntürést. A kontrollnövényben is jelenlévő, a kezelés hatására erősödő nitráció összefüggése a toleranciával nem egyértelmü, ezt minden növényfajban a fiziológiás nitroproteom tükrében kell vizsgálni, s ahhoz viszonyítani az kezelt növényeket. Eredményeink alapján az elmondható, hogy a toleráns növényfajok plasztikusabban képesek kezelni az RNF-metabolizmust és feltételezhetően jobban türik a fehérjenitrációt, ami hozzájárul a toleranciához. A különböző növényfajokban lejátszódó folyamatokat egy sematikus ábrán foglalom össze (33. ábra).

A kísérletek során a proteintirozin-nitráció és szelénstressz közötti kapcsolat néhány aspektusát sikerült részletesen felderítenünk, mely irodalmilag új adatnak számít. Nem szabad azonban eltekinteni a nitrozatív stresszben szerepet játszó más makromolekula-módosításoktól sem, mint a fehérje- $S$-nitroziláció, lipid- és nukleinsav-nitráció, melyek hatását a legfrissebb kutatások bizonyították növényekben. A szeléntoxicitás és nitro-oxidatív stressz kapcsolatának teljes felderítéséhez e folyamatok vizsgálata elengedhetetlenül szükséges lesz a jövőben. 
Szelenit és érzékeny növényfajok

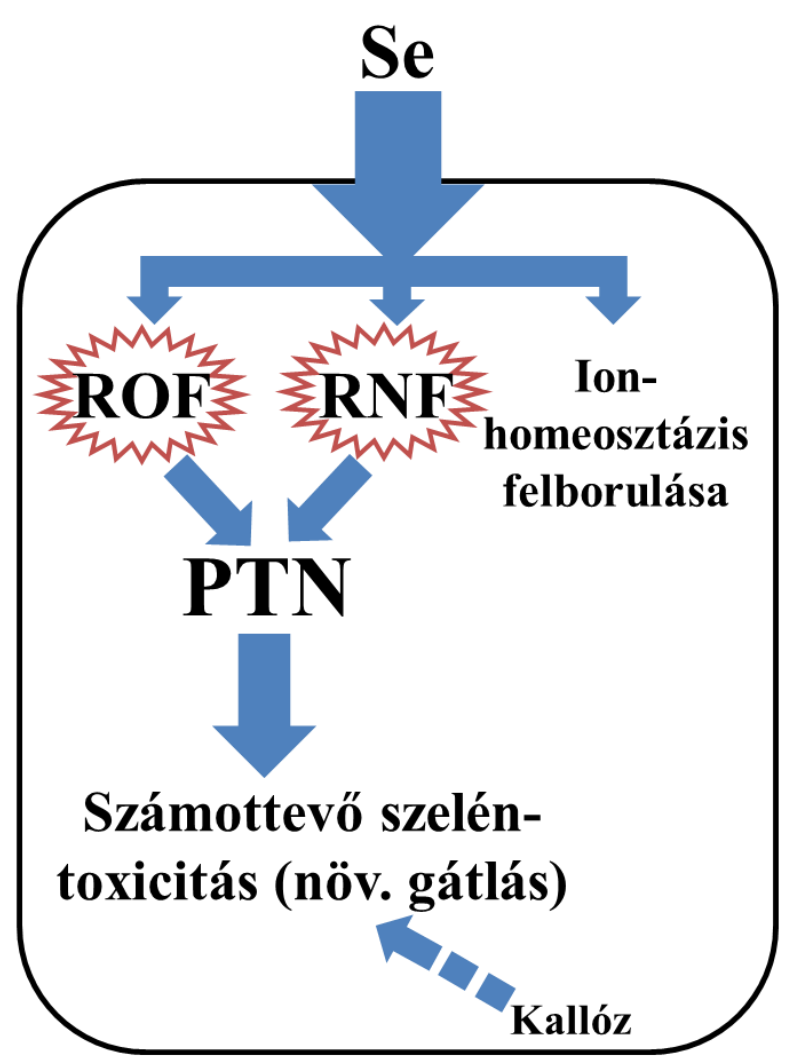

Szelenát és toleráns növényfajok

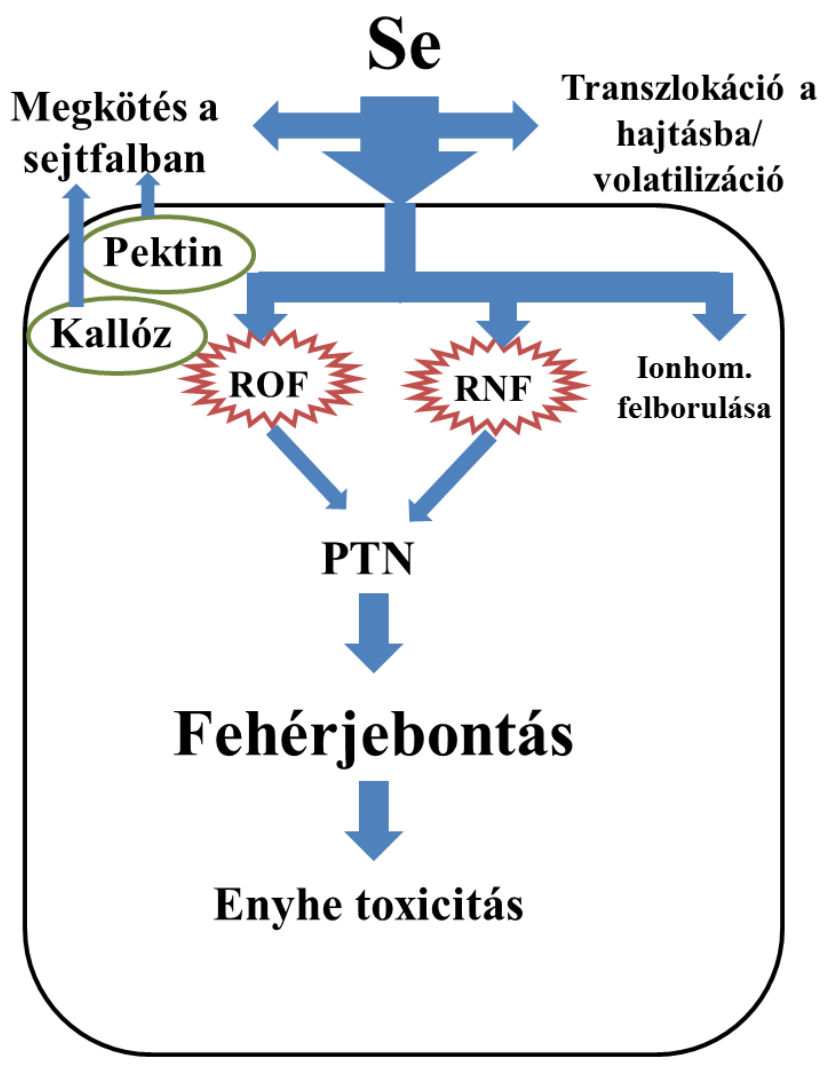

33. ábra A különböző mértékủ szeléntoxicitás hátterében álló folyamatok sematikus vázlata eredményeink alapján. A feliratok nagysága ábrázolja a folyamat intenzitását a sejtben. A teljes leírás a szövegben megtalálható. Az ábrán használt rövidítések: reaktív oxigénformák (ROF), reaktív nitrogénformák (RNF), proteintirozin-nitráció (PTN). 


\section{Köszönetnyílvánítás}

Elsőként szeretném megköszönni témavezetőmnek, Ördögné Dr. Kolbert Zsuzsannának az elmúlt évek alatt nyújtott felbecsülhetetlen segítségét. A szakmai tapasztalata $\mathrm{s}$ tudása nélkülözhetetlennek bizonyult a kutatói pálya megkezdésében. Hála neki, számos lehetőséget kaptam hazai és nemzetközi konferenciákon való részvételben, valamint számos díjat is elnyertem. Kiváló munkáját ékesen bizonyítja, hogy az elmúlt évek során számos publikáció megszületésében vehettem részt. Öszintén köszönöm a rengeteg munkát, időt és türelmet, melyet rám áldozott az elmúlt időszak folyamán!

Köszönetet mondanék Dr. Fehér Attila Tanszékvezető egyetemi tanárnak, hogy lehetöséget teremtett a Növénybiológiai Tanszék munkájába való bekapcsolódáshoz, s hogy biztosította a dolgozat kísérleteihez a szükséges környezetet. Köszönöm támogatását és bizalmát, mely hozzájárult a doktori munkám megszületéséhez.

Szeretném megköszönni a SZTE Reaktív Nitrogénforma jelátviteli kutatócsoport valamennyi jelenlegi s múltbéli tagjának, hiszen segítségük és támogatásuk nélkül nem jöhetett volna létre a dolgozat. Kiemelném közülük Dr. Feigl Gábort, aki rendíthetetlen kitartással tanított be a módszerekre minden hibám ellenére, melynek hála egy módszertanilag szerteágazó dolgozatot készíthettem. Köszönetet mondanék Dr. Szöllősi Rékának a mikroszkópos minták előkészítésében nyújtott segítségéért. Hálásan köszönöm Kapásné Török Éva fáradhatatlan munkáját, melynek hála a kísérleteket elvégezhettem. Köszönet illeti a szakdolgozóimat, Trifán Vandát, Szabó Zsuzsannát és Kéri Krisztinát, hogy segédkeztek a kísérletek elvégzésében.

Szeretném megköszönni Dr. Ördög Attilának a növények ültetésében és az induktív csatolású plazma tömegspektrometriás vizsgálatokban nyújtott odaadó munkáját.

Köszönetet mondanék a Növénybiológiai Tanszék valamennyi jelenlegi és múltbéli munkatársának, hiszen odaadó támogatásuk és segítségük nélkül nem jöhetett volna létre a dolgozat.

Köszönet illeti az SZTE Szervetlen és Analitikai Kémiai Tanszékének munkatársait, akik az elemtartalom analízissel nagy segítségemre voltak a munkám során.

S végül, de nem utolsó sorban, hálával tartozom mindazon szeretteimnek és barátaimnak, akik támogattak az évek során, s mellettem álltak az életem ezen szakaszában. 


\section{Irodalomjegyzék}

1. Adriano DC (2001) Trace elements in terrestrial environments. Biogeochemistry, bioavailability and risks of metals (2nd edn) Springer-Verlag, New York

2. Airaki M, Leterrier M, Mateos RM, Valderrama R, Chaki M, Barroso JB, del Río LA, Palma JM, Corpas FJ (2012) Metabolsim of reactive oxygen species and reactive nitrogen species in pepper (Capsicum annuиm L.) plants under low temperature stress. Plant Cell Environ 35:281-295.

3. Airaki M, Sánchez-Moreno L, Leterrier M, Barroso JB, Palma JM, Corpas FJ (2011) Detection and quantification of S-nitrosoglutathione (GSNO) in pepper (Capsicum annuum L.) plant organs by LC-ES/MS. Plant Cell Phys 52:2006-2015.

4. Alamillo JM, García-Olmedo F (2001) Effects of urate, a natural inhibitor of peroxynitrite-mediated toxicity, in the response of Arabidopsis thaliana to the bacterial pathogen Pseudomonas syringae. The Plant J 25:529-540.

5. Ali MB, Singh N, Shohael AM, Hahn EJ, Paek KY (2006) Phenolics metabolism and lignin synthesis in root suspension cultures of Panax ginseng in response to copper stress. Plant Science 171:147-154.

6. Alves LR, Prado ER, de Oliveira R, Santos E, Souza I, Reis A, Azevedo R, Gratão P (2020) Mechanisms of cadmium-stress avoidance by selenium in tomato plants. Ecotoxicology DOI: $10.1007 / \mathrm{s} 10646-020-02208-1$

7. Amenos M, Corrales I, Poschenrieder C, Illes P, Baluska F, Barcelo J (2009) Different effects of aluminum on the actin cytoskeleton and Brefeldin A-sensitive vesicle recycling in root apex cells of two maize varieties differing in root elongation rate and aluminum tolerance. Plant Cell Physiol 50:528-540.

8. Andryka-Dudek P, Ciacka K, Wiśniewska A, Bogatek R, Gniazdowska A (2019) Nitric oxide-induced dormancy removal of apple embryos is linked to alterations in expression of genes encoding ABA and JA biosynthetic or transduction pathways and RNA nitration. International Journal of Molecular Sciences 20:1007.

9. Arasimowicz-Jelonek M, Floryszak-Wieczorek J (2011) Understanding the fate of peroxynitrite in plant cells - from physiology to pathophysiology. Phytochemistry 72:681-688.

10. Arasimowicz-Jelonek M, Floryszak-Wieczorek J, Kubiś J (2009) Involvement of nitric oxide in water stressinduced responses of cucumber roots. Plant Sci 177:682-690.

11. Arduini I, Godbold DL, Onnis A (1995) Influence of copper on root growth and morphology of Pinus pinea L. and Pinus pinaster Ait. seedlings. Tree Physiol 15:411-415.

12. Arnaud J, van Dael P (2018) Selenium Interactions with Other Trace Elements, with Nutrients (and Drugs) in Humans. In: Michalke B. (eds) Selenium. Molecular and Integrative Toxicology. Springer, Cham

13. Arvy MP (1993) Selenate and selenite uptake and translocation in bean plants (Phaseolus vulgaris). J Exp Bot 44:1083-1087.

14. Bachiega P, Salgado JM, de Carvalho JE, Ruiz ALT, Schwarz K, Tezotto T, Morzelle MC (2016) Antioxidant and antiproliferative activities in different maturation stages of broccoli (Brassica oleracea Italica) biofortified with selenium. Food Chem 190:771-776.

15. Baker AJ, McGrath SP, Reeves RD, Smith JAC (2000) Metal hyperaccumulator plants: a review of the ecology and physiology of a biological resource for phytoremediation of metal polluted soils. In: Terry N, Bañuelos GS (eds) Phytoremediation of contaminated soil and water. CRC Press, Boca Raton, 85-107.

16. Baluska F, Liners F, Hlavacka A, Schlicht M, van Cutsem P, McCurdy DW, Menzel D (2005) Cell wall pectins and xyloglucans are internalised into dividing root cells and accumulate within cell plates during cytokinesis. Protoplasma 225:141-155.

17. Bañuelos GS, Ajwa HA, Terry N, Zayed A (1997) Phytoremediation of selenium laden soils: a new technology. J Soil Water Conserv 52:426-430.

18. Barillas JRV, Quinn CF, Freeman JL, Lindblom SD, Fakra SC, Marcus MA, Gilligan TM, Alford ER, Wangeline AL, Pilon-Smits EAH (2012) Selenium distribution and speciation in the hyperaccumulator Astragalus bisulcatus and associated ecological partners. Plant Physiol 159:1834-1844.

19. Barroso JB, Corpas FJ, Carreras A, Rodríguez-Serrano M, Esteban FJ, Fernandez-Ocana A (2006) Localization of S-nitrosoglutathione and expression of S-nitrosoglutathione reductase in pea plants under cadmium stress. J Exp Bot 57:1785-1793.

20. Barroso JB, Valderrama R, Corpas FJ (2013) Immunolocalization of S-nitrosoglutathione, S-nitrosoglutathione reductase and tyrosine nitration in pea leaf organelles. Acta Physiol Plant 35:2635-2640.

21. Beauchamp C, Fridovich I (1971) Superoxide dismutase: improved assays and an assay applicable to acrylamide gels. Anal Biochem 44:276-287.

22. Begara-Morales JC, Chaki M, Valderrama R, Sánchez-Calvo B, Mata-Pérez C, Padilla MN, Corpas FJ, Barroso JB (2018) NO buffering and conditional NO release in stress response. J Exp Bot 69(14):3425-3438. 
23. Begara-Morales JC, Sánchez-Calvo B, Chaki M, Mata-Pérez C, Valderrama R, Padilla MN, López-Jaramillo J, Luque F, Corpas FJ, Barroso JB (2015) Differential molecular response of monodehydroascorbate reductase and glutathione reductase by nitration and S-nitrosylation. J Exp Bot 66:5983-5996.

24. Begara-Morales JC, Sánchez-Calvo B, Chaki M, Valderrama R, Mata-Pérez C, López-Jaramillo J, Padilla MN, Carreras A, Corpas FJ, Barroso JB (2014) Dual regulation of cytosolic ascorbate peroxidase (APX) by tyrosine nitration and S-nitrosylation. J Exp Bot 65:527-538.

25. Begara-Morales JC, Sánchez-Calvo B, Gómez-Rodríguez MV, Chaki M, Valderrama R, Mata Pérez C, LópezJaramillo J, Corpas FJ, Barroso JB (2019) Short-Term Low Temperature Induces Nitro Oxidative Stress that Deregulates the NADP-Malic Enzyme Function by Tyrosine Nitration in Arabidopsis thaliana. Antioxidants (Basel) 8:448.

26. Bethke PC, Badger MR, Jones RL (2004) Apoplastic synthesis of nitric oxide by plant tissues. Plant Cell 16:332341.

27. Blum H, Beier H, Gross HJ (1987) Improved silver staining of plant proteins, RNA and DNA in polyacrylamide gels. Electrophoresis 8:93-99.

28. Bradford MM (1976) A rapid and sensitive method for the quantification of microgram quantities of protein utilizing the principle of protein-dye-binding. Anal Biochem 72:248-255.

29. Broniowska KA, Diers AR, Hogg N (2013) S-Nitrosoglutathione. Biochim Biophys Acta 1830:3173-3181.

30. C Welinder, L Ekblad (2011) Coomassie staining as loading control in Western blot analysis J Proteome Res 10:1416-1419.

31. Cao Y, Lou Y, Han Y Shi J, Wang Y, Wang W, Ming F (2011) Al toxicity leads to enhanced cell division and changed photosynthesis in Oryza rufipogon L. Mol Biol Rep 38:4839.

32. Cartes P, Gianfreda L, Mora ML (2005) Uptake of selenium and its antioxidant activity in ryegrass when applied as selenate and selenite forms. Plant Soil 276:359-367.

33. Cartes P, Jara AA, Pinilla L, Rosas A, Mora ML (2010) Selenium improves the antioxidant ability against aluminium-induced oxidative stress in ryegrass roots. Annals of Applied Biology 156:297-307.

34. Castillo MC, Lozano-Juste J, Gonzalez-Guzman M, Rodriguez L, Rodriguez PD, Leon J (2015) Inactivation of PYR/PYL/RCAR ABA receptors by tyrosine nitration may enable rapid inhibition of ABA signaling by nitric oxide in plants. Sci Signal 8:392.

35. Caverzan A, Casassola A, Brammer SP (2016) Antioxidant responses of wheat plants under stress. Genetics and Molecular Biology 39:1-6.

36. Cecconi D, Orzetti S, Vandelle E, Rinalducci S, Zolla L, Delledonne M (2009) Protein nitration during defense response in Arabidopsis thaliana. Electrophoresis 30:2460-2468.

37. Chaki M, Carreras A, López-Jaramillo J, Begara-Morales JC, Sánchez-Calvo B, Valderrama R, Corpas FJ, Barroso JB (2013) Tyrosine nitration provokes inhibition of sunflower carbonic anhydrase (-CA)activity under high temperature stress. Nitric Oxide 29:30-33.

38. Chaki M, Fernández-Ocana AM, Valderrama R, Carreras A, Esteban FJ, Luque F, Gómez-Rodríguez MV, BeragaMorales JC, Corpas FJ, Barroso JB (2009) Involvement of reactive oxygen and nitrogen species (ROS and RNS) in sunflower-mildew interaction. Plant Cell Phys 50:265-279.

39. Chaki M, Valderrama R, Fernandez-Ocana AM, Carreras A, Gomez-Rodriguez MV, Lopez-Jaramillo J, BegaraMorales JC, Sanchez-Calvo B, Luque F, Leterrier M, Corpas FJ, Barroso JB (2011) High temperature triggers the metabolism of $\mathrm{S}$ nitrosothiols in sunflower mediating a process of nitrosative stress which provokes the inhibition of ferredoxin-NADP reductase by tyrosine nitration. Plant Cell Environ 34(11):1803-18.

40. Chamizo-Ampudia A, Sanz-Luque E, Llamas Á, Ocaña-Calahorro F, Mariscal V, Carreras A, Barroso JB, Galván A, Fernández E (2016) A dual system formed by the ARC and NR molybdoenzymes mediates nitrite-dependent NO production in Chlamydomonas. Plantcell Environ 39:2097-2107.

41. Chen JJ, Boylan LM, Wu CK, Spallholz JE (2007) Oxidation of glutathione and superoxide generation by inorganic and organic selenium compounds. Biofactors 31:55-66.

42. Chen Y, Mo HZ, Zheng, MY, Xian M, Qi ZQ, Li YQ, Hu LB, Chen J, Yang LF (2014) Se inhibits root elongation by repressing the generation of endogenous hydrogen sulfide in Brassica rapa. PLoS ONE 9, e110904.

43. Claus H (2004) Laccases: Structure, reaction, distribution. Micron 35:93-96.

44. Cooney RV, Harwood PJ, Custer LJ, Franke AA (1994) Light-mediated conversion of nitrogen dioxide to nitric oxide by carotenoids. Environ Health Persp. 102:460-462.

45. Corpas FJ, Barroso JB (2013) Nitro-oxidative stress vs oxidative or nitrosative stress in higher plants. New Phytologist 199(3):633-635

46. Corpas FJ, Barroso JB (2017) Nitric oxide synthase-like activity in higher plants. Nitric Oxide Biol Chem 68:5. 
47. Corpas FJ, Carreras A, Esteban FJ, Chaki M, Valderrama R, del Río LA, Bassoso JB (2008) Localization of Snitrosothiols and assay of nitric oxide synthase and S-nitrosoglutathione reductase activity in plants. Methods Enzymol 437:561-574.

48. Corpas FJ, Carreras A, Valderrama R, Chaki M, Palma JM, del Río LA, Barroso JB (2007) Reactive nitrogen species and nitrosative stress in plants. Plant Stress 1:37-41.

49. Corpas FJ, Palma JM (2018) Assessing Nitric Oxide (NO) in Higher Plants: An Outline. Nitrogen 1:12-20.

50. Corpas FJ, Palma JM, DelRío LA, Barroso JB (2009) Evidence supporting the existence of L-arginine-dependent nitric oxide synthase activity in plants. New Phytol 184:9-14.

51. Correa-Aragunde N, Foresi N, Del Castello F, Lamattina LA (2018) singular nitric oxide synthase with a globin domain found in Synechococcus PCC 7335 mobilizes N from arginine to nitrate. Sci Rep 8:12505.

52. Cosgrove DJ (1997) Assembly and enlargement of the primary cell wall in plants. Annu Rev Cell Dev Biol 13:171-201.

53. Craig PJ (1986) Organometallic Compounds in the Environment, Longman Group Ltd. London 255-277.

54. Cumming JR, Taylor GJ (1990) Mechanism of metal tolerance in plants: physiological adaptations for exclusion of metal ions from the cytoplasm. In: Alscher RG, Cumming JR (eds) Stress response in plants: adaptation and acclimation mechanism. Wiley-Liss, New York 329-356.

55. Dalla Vecchia F, Cuccato F, La Rocca N, Larcher W, Rascio N (1999) Endodermis-like sheaths in the submerged freshwater macrophyte Ranunculus trichophyllus Chaix. Ann Bot 83:93-97.

56. Dalton TP, Shertzer HG, Puga A (1999) Regulation of gene expression by reactive oxygen. Annual Review of Pharmacology and Toxicology 39:67-101.

57. de Souza MP, EAH P-S, Lytle CM (1998) Rate limiting steps in selenium assimilation and volatilization by Indian mustard. Plant Physiol 117:1487-1494.

58. de Souza MP, Pilon-Smits EAH, Terry N (1999): The physiology and biochemistry of selenium volatilisation by plants; In: Ruskin, I.; Ensley, B. D. (eds.), Phytoremediation of toxic metals; Wiley, New York

59. De Vos CHR, Vonk MJ, Voojis R, Schat H (1992) Glutathione depletion due to copper-induced phytochelatin sythesis causesoxidative stress in Silene cucbalus. Plant Physiology 98:853-858.

60. del Río LA, Sandalio FM, Corpas FJ, Palma JM, Barroso JB (2006) Reactive oxygen species and reactive nitrogen species in peroxisomes. Production, scavenging, and role in cell signaling. Plant Physiology 141:330-335.

61. Delledonne M, Zeier J, Marocco A, Lamb C (2001) Signal interactions between nitric oxide and reactive oxygen intermediates in the plant hypersensitive disease resistance response. Proc Natl Acad Sci 98:13454-13459.

62. Dhindsa RS, Plumb-Dhindsa P, Thorpe TA (1981) Leaf senescence: correlated with increased levels of membrane permeability and lipid peroxidation, and decreased levels of superoxide dismutase and catalase. J Exp Bot 32:93101.

63. Dietz KJ, Baier M, Krämer U (1999) Free radicals and reactive oxygen species as mediators of heavy metal toxicity in plants. In: Hagemeyer J (ed.) Heavy metal stress in plants, Prasad MNV, Springer-Verlag, 73-97.

64. Dimkovikj A, Fisher B, Hutchison K, Van Hoewyk D (2015) Stuck between a ROS and a hard place: analysis of the ubiquitin proteasome pathway in selenocysteine treated Brassica napus reveals different toxicities during selenium assimilation. J Plant Physiol 181:50-54.

65. Dimkovikj A, Van Hoewyk D (2014) Selenite activates the alternative oxidase pathway and alters primary metabolism in Brassica napus roots: evidence of a mitochondrial stress response. BMC Plant Biol 14:259.

66. Djanaguiraman M, Prasad PV, Seppanen M (2010) Selenium protects sorghum leaves from oxidative damage under high temperature stress by enhancing antioxidant defense system. Plant Physiol Biochem 48:999-1007.

67. Domokos-Szabolcsy E, Alshaal T, Elhawat N, Abdalla N, Reis A, El-Ramady H (2017) The Interactions between Selenium, Nutrients and Heavy Metals in Higher Plants under Abiotic Stresses. Env. Biodiv. Soil Security. 1:4-30.

68. Dordas C, Hasinoff BB, Igamberdiev AU, Manac'h N, Rivoal J, Hill RD (2003) Expression of a stress-induced hemoglobin affects NO levels produced by alfalfa root cultures under hypoxic stress. The Plant Journal vol 35(6):763-770.

69. Douchiche O, Driouich A, Morvan C (2010) Spatial regulation of cell wall structure in response to heavy metal stress: Cadmium-induced alteration of the methyl-esterification pattern of homogalacturonans. Ann Bot 105: 481491.

70. Drazkiewicz M, Skórzynska-Polit E, Krupa Z (2003) Response of the ascorbate-glutathione cycle to excess copper in Arabidopsis thaliana (L.). Plant Science 164:195-202.

71. Durand C, Vicré-Gibouin M, Follet-Gueye ML, Duponchel L, Moreau M, Lerouge P, Driouich A (2009) The organization pattern of root border-like cells of Arabidopsis is dependent on cell wall homogalacturonan. Plant Physiol 150:1411-1421. 
72. Ebrahimi N, Hartikainen H, Simojoki A, Hajiboland R, Seppänen M (2015) Dynamics of dry matter and selenium accumulation in oilseed rape (Brassica napus L.) in response to organic and inorganic selenium treatments. Agric Food Sci 24(2):104-117.

73. Ekanayake LJ, Vial E, Schatz B, McGee R, Thavarajah P (2015) Selenium fertilization on lentil (Lens culinaris Medikus) grain yield, seed selenium concentration, and antioxidant activity. Field Crops Res 177:9-14.

74. Eleftheriou EP, Adamakis I-D, Panteris E, Fatsio M (2015) Chromium-induced ultrastructural changes and oxidative stress in roots of Arabidopsis thaliana. Int J Mol Sci 16:15852-15871.

75. Elkelish AA, Soliman HM, Alhaithloul HA, El-Esawi MA (2019) Selenium protects wheat seedlings against salt stress-mediated oxidative damage by up-regulating antioxidants and osmolytes metabolism. Plant Physiology and Biochemistry 137:144-153.

76. El-Moneim DA, Contreras R, Silva-Navas J, Gallego JF, Figueiras AM, Benito C (2014) Pectin methylesterase gene and aluminum tolerance in Secale cereal. Environ Exp Bot 107:125-133.

77. El-Ramady H, Abdalla N, Alshaal T, El-Henawy A, Faizy SEDA, Shams MS, Shalaby T, Bayoumi Y, Elhawat N, Shehata S, Sztrik A, Prokisch J, Fári M, Pilon-Smits EAM, Domokos-Szabolcsy (2015) Selenium and its Role in Higher Plants; E. Lichtfouse et al. (eds.), Pollutants in Buildings, Water and Living Organisms. Environmental Chemistry for a Sustainable World, 7:235-296.

78. Elstner EF (1987) Metabolism of activated oxygen species, In: D.D.Davies (ed) The Biochemistry of Plants: A Comprehensive Treatise, vol. 8, Elsevier, 253-315.

79. Espunya MC, De Michele R, Gómez-Cadenas A, Martínez MC (2012) S-Nitrosoglutathione is a component of wound- and salicylic acid-induced systemic responses in Arabidopsis thaliana. J Exp Bot 63:3219-3227.

80. Eticha D, Stass A, Horst WJ (2005) Cell-wall pectin and its degree of methylation in the maize root apex: Significance for genotypic differences in aluminium resistance. Plant Cell Env 28:1410-1420.

81. Exposito-Rodriguez M, Laissue PP, Yvon-Durocher G, Smirnoff N, Mullineaux PM (2017) Photosynthesisdependent $\mathrm{H} 2 \mathrm{O} 2$ transfer fromchloroplasts to nuclei provides a high-light signalling mechanism. Nature Communications 8:1.

82. Fares A, Rossignol M, Peltier JB (2011) Proteomics investigation of endogenous S-nitrosylation in Arabidopsis. Biochem Biophys Res Commun 416:331-336.

83. Feigl G, Kumar D, Lehotai N, Tugyi N, Molnár Á, Ördög A, Szepesi Á, Gémes K, Laskay G, Erdei L, Kolbert Zs (2013) Physiological and morphological responses of the root system of Indian mustard (Brassica juncea $\mathrm{L}$.

Czern.) and rapeseed (Brassica napus L.) to copper stress. Ecotoxicol Environ Saf 94:179-189.

84. Feigl G, Lehotai N, Molnár A, Ördög A, Rodríguez-Ruiz M, Palma J M, Corpas FJ, Erdei L, Kolbert Z (2015) Zinc induces distinct changes in the metabolism of reactive oxygen and nitrogen species (ROS and RNS) in the roots of two Brassica species with different sensitivity to zinc stress. Ann Bot 116:613-625.

85. Filek M, Zembala M, Kornas A, Walas S, Mroviec H, Hartikainen H (2010) The uptake and translocation of macro- and microelements in rape and wheat seedlings as affected by selenium supply level. Plant Soil 336:303312.

86. Fisher B, Yarmolinsky D, Abdel-Gany S, Pilon M, Pilon-Smits EA, Sagi M, Van Hoewyk D (2016) Superoxide generated from the glutathione-mediated reduction of selenite damages the iron-sulphur cluster of chloroplastic ferredoxin. Plant Physiol Biochem 106:228-235.

87. Fordyce F (2005) Selenium deficiency and toxicity in the environment. In: Selinus O, Alloway B, Centeno J, Finkelman R, Fuge R, Lindh U, Smedley P (Eds.) Essentials of Medical Geology. Elsevier, London, 373-415.

88. Foresi N, Correa-Aragunde N, Parisi G, Caló G, Salerno G, Lamattina L (2010) Characterization of a nitric oxide synthase from the plant kingdom: NO generation from the green alga Ostreococcus tauri is light irradiance and growth phase dependent. Plant Cell 22:3816-3830.

89. Foyer CH, Noctor G (2011) Ascorbate and glutathione: the heart of the redox hub. Plant Phys 155:55-64.

90. Foyer CH, Ruban AV, Noctor G (2017) Viewing oxidative stress through the lens of oxidative signalling rather than damage. Biochem J 474:877-883.

91. Freeman JL, Tamaoki M, Stushnoff C, Quinn CF, Cappa JJ, Devonshire J, Fakra SC, Marcus MA, McGrath SP, Van Hoewyk D, Pilon-Smits EAH (2010) Molecular mechanisms of selenium tolerance and hyperaccumulation in Stanleya pinnata. Plant Physiol 153:1630-1652.

92. Freeman JL, Zhang LH, Marcus MA, Fakra S, Pilon-Smits EAH (2006) Spatial imaging, speciation and quantification of selenium in the hyperaccumulator plants Astragalus bisulcatus and Stanleya pinnata. Plant Physiol 142:124-134.

93. Garcia-Banuelos ML, Hermosillo-Cereceres A, Sanchez EM (2011) The importance of selenium biofortification in food crops. Curr Nutr Food Sci 7:181-190.

94. Garousi F (2015) The toxicity of different selenium forms and compounds - review. Agrártud Közl 64:33-38. 
95. Geoffery L, Gilbin R, Simon O, Floriani M, Adam C, Pradines C, Cournac L, Garnier-Laplace J (2007) Effect of selenate on growth and photosynthesis of Chlamydomonas reinhardtii. Aquat Toxicol 83:149-158.

96. Germ M, Stibilj V, Kreft I (2007) Metabolic importance of selenium for plants. Eur J Plant Sci Biotech 1:91-97.

97. Gietler M, Nykiel M, Orzechowski S, Fettke J, Zagdánska B (2016) Proteomic analysis of S-nitrosylated and Sglutathionylated proteins in wheat seedlings with different dehydration tolerances. Plant Physiol Biochem 108:507-518.

98. Gill SS, Anjum NA, Hasanuzzaman M, Gill R, Kumar DT, Ahmad I, Pereira E, Tuteja N (2013) Glutathione and glutathione reductase: a boon in disguise for plant abiotic stress defense operations. Plant Phys Biochem 70:204212.

99. Golob A, Stibilj V, Kreft I, Vogel-Mikuš K, Gabeř̌čik A, Germ M (2018) Selenium treatment alters the effects of UV radiation on chemical and production parameters in hybrid buckwheat. Acta Agriculturae Scandinavica, Section B - Soil \& Plant Science 68:5-15.

100. Goretski J, Hollocher TC (1988) Trapping of nitric oxide produced during denitrification by extracellular hemoglobin. J Biol Chem 263:2316-23

101. Gow AJ, Farkouh CR, Munson DA, Posencheg MA, Ischiropoulos H (2004) Biological significance of nitric oxide-mediated protein modifications. Am J Physiol Lung Cell Mol Physiol 287:262-268.

102. Grant K, Carey NM, Mendoza M, Schulze J, Pilon M, Pilon-Smits EA, van Hoewyk D (2011) Adenosine 5phosphosulfate reductase (APR2) mutation in Arabidopsis implicates glutathione deficiency in selenate toxicity. Biochem J 438:325-335.

103. Guerra D, Ballard K, Truebridge I, Vierling E (2016) S-nitrosation of conserved cysteines modulates activity and stability of S-nitrosoglutathione reductase (GSNOR). Biochemistry 55:2452-2464.

104. Guignardi Z, Schiavon M (2017) Biochemistry of Plant Selenium Uptake and Metabolism. In: Pilon-Smits E, Winkel L, Lin ZQ (eds) Selenium in plants. Plant Ecophysiology, vol 11. Springer, Cham

105. Haghighi M, da Silva JAT (2016) Influence of selenium on cadmium toxicity in cucumber (Cucumis sativus cv. $4200)$ at an early growth stage in a hydroponic system. Communications in Soil Science and Plant Analysis 47:142-155.

106. Haghighi M, Sheibanirad A, Pessarakli M (2016) Effects of Se as a beneficial element on growth and photosynthetic attributes of greenhouse cucumber. J Plant Nutr 39:1493-1498.

107. Hajiboland R, Keivanafar N (2012) Selenium supplementation stimulates vegetative and reproductive growth in canola (Brassica napus L.) plants. Acta Agric Slov 99-1:13-19.

108. Hajiboland R, Rahmat S, Aliasgharzad N, Hartikainen H (2015) Se-induced enhancement in carbohydrate metabolism in nodulated alfalfa (Medicago sativa $\mathrm{L}$.) as related to the glutathione redox state. Soil Sci Plant Nutr 61:676-687.

109. Hajiboland R, Rahmat S, Zeinalzadeh N, Farsad-Akhtar N, Hosseinpour-Feizi MA (2019) Senescence is delayed by selenium in oilseed rape plants. J Trace Elem Med Biol 55:96-106.

110. Han D, Li X, Xiong S, Tu S, Chen Z, Li J, Xie Z (2013) Selenium uptake, speciation, and stress response of Nicotiana tabacum L. Environmental and Experimental Botany 95:6-14.

111. Hancock JT, Neill SJ (2019) Nitric Oxide: Its generation and interactions with other reactive signaling compounds. Plants 8:41.

112. Handa N, Kohli SK, Sharma A, Thukral AK, Bhardwaj R, Abd Allah EF, Alqarawi AA, Ahmad P (2019) Selenium modulates dynamics of antioxidative defence expression, photosynthetic attributes and secondary metabolites to mitigate chromium toxicity in Brassica juncea L. plants. Environ Exp Bot 161:180-192.

113. Harris J, Schneberg KA, Pilon-Smits EAH (2014) Sulfur-selenium-molybdenum interactions distinguish selenium hyperaccumulator Stanleya pinnata from non-hyperaccumulator Brassica juncea (Brassicaceae). Planta 239:479-491.

114. Hartikainen H, Xue T, Piironen V (2000) Selenium as an anti-oxidant and pro-oxidant in ryegrass. Plant and Soil 225:193-200.

115. Hartley DP, Kolaja KL, Reichard J, Petersen DR (1999) 4-Hydroxynonenal and malondialdehyde hepatic protein adducts in rats treated with carbon tetrachloride: immunochemical detection and lobular localization. Toxicol Appl Pharmacol 161:23-33.

116. Hawkesford MJ (2005) Sulphur. In: Broadley MR, White PJ (eds) Plant nutritional genomics. Oxford: Blackwell, 87-111.

117. Hawrylak-Nowak B (2008) Changes in anthocyanin content as indicator of maize sensitivity to Se. J Plant Nutr 31:1232-1242.

118. Hawrylak-Nowak B (2015) Selenite is more efficient than selenate in alleviation of salt stress in lettuce plants. Acta Biologica Cracoviensia s Botanica 57:49-54. 
119. Hawrylak-Nowak B, Matraszek R, Pogorzelec M (2015) The dual effects of two inorganic selenium forms on the growth, selected physiological parameters and macronutrients accumulation in cucumber plants. Acta Physiol Plant 37: 41 .

120. Hazebrouck S, Camoin L, Faltin Z, Strosberg AD, Eshdat Y (2000) Substituting selenocysteine for catalytic cysteine 41 enhances enzymatic activity of plant phospholipid hydroperoxide glutathione peroxidase expressed in Escherichia coli. J Biol Chem 275:28715-28721.

121. Hebelstrup KH, Hunt P, Dennis E, Jensen SB, Jensen EO (2006) Hemoglobin is essential for normal growth of Arabidopsis organs. Physiologia Plantarum 127:157-166.

122. Henry Y, Guissani A (1999) Interactions of nitric oxide with hemoproteins: Roles of nitric oxide in mitochondria. Cell Mol Life Sci 55:1003-1014.

123. Hondal RJ, Marino SM, Gladyshev VN (2013) Selenocysteine in thiol/disulfide-like exchange reactions. Antiox Redox Signal 18:1675-1689.

124. Horst WJ, Wang Y,Eticha D (2010) The role of the root apoplast in Aluminum-induced inhibition of root elongation and in aluminum resistance of plant. Rev Ann Bot 106:185-197.

125. Hossain AKMZ, Koyama H, Hara T (2006) Growth and cell wall properties of two wheat cultivars differing in their sensitivity to aluminum stress. J Plant Physiol 2006 163:39-47.

126. Hossain MA, Bhattacharjee S, Armin S, Qian P, Xin W, Li HY, Burritt DJ, Fujita M, Tran LS (2015) Hydrogen peroxide priming modulates abiotic oxidative stress tolerance: insights from ROS detoxification and scavenging. Frontiers in Plant Science 6:420.

127. Houston K, Tucker MR, Chowdhury J, Shirley N and Little A (2016) The plant cell wall: a complex and dynamic structure as revealed by the responses of genes under stress conditions. Front. Plant Sci 7:984.

128. Hu J, Huang X, Chen L, Sun X, Lu C, Zhang L, Wang Y, Zuo J (2015) Site-specific nitrosoproteomic identification of endogenously S-nitrosylated proteins in Arabidopsis. Plant Physiol 167:1731-1746.

129. Hu QH, Pan GX, Zhu JC (2001) Effect of se on green tea preservation quality and amino acid composition of tea protein. J Hortic Sci Biotechnol 76:344-346.

130. Hugouvieux V, Dutilleul C, Jourdain A, Reynaud F, Lopez V, Bourguignon J (2009) Arabidopsis putative selenium-binding protein1 expression is tightly linked to cellular sulfur demand and can reduce sensitivity to stresses requiring glutathione for tolerance. Plant Physiol 151:768-781.

131. Ischiropoulos H, Zhu L, Chen J, Tsai M, Martin JC, Smith CD, Beckman JS (1992) Peroxynitrite-mediated tyrosine nitration catalyzed by superoxide dismutase. Arch Biochem Biophys 298:431-437.

132. Izbiańska K, Floryszak-Wieczorek J, Gajewska J, Meller B, Kuźnicki D, Arasimowicz-Jelonek M (2018) RNA and mRNA Nitration as a Novel Metabolic Link in Potato Immune Response to Phytophthora infestans. Front Plant Sci 9:672.

133. Jahnová J, Luhová L, Petřivalský M (2019) S-nitrosoglutathione reductase-the master regulator of protein Snitrosation in plant NO signalling. Plants 8:48.

134. Jajic I, Sarna T, Strzalka K (2015) Senescence, stress, and reactive oxygen species. Plants 4: 393-411.

135. Jeandroz S, Lamotte O, Astier J, Rasul S, Trapet P, Besson-Bard A, Bourque S, Nicolas-Francès V, Ma W, Berkowitz GA, Wendehenne D (2013) There's more to the picture than meets the eye: nitric oxide cross talk with Ca2+ signaling. Plant Phys 163:459-470.

136. Jena NR, Mishra PC (2007) Formation of 8-nitroguanine and 8-oxoguanine due to reactions of peroxynitrite with guanine. J Comput Chem 28:1321-35.

137. Jiang C, Zu C, Shen J, Shao F, Li T (2015) Effects of Se on the growth and photosynthetic characteristics of fluecured tobacco (Nicotiana tabacum L.). Acta Soc Bot Pol 84: 71-77.

138. Jiang J, Tang X, Xue Y, Lin G, Xiong YL (2017) Dietary linseed oil supplemented with organic Se improved the fatty acid nutritional profile, muscular Se deposition, water retention, and tenderness of fresh pork. Meat Sci 131:99-106.

139. Jiang X, Wang C (2008) Zinc distribution and zinc-binding forms in Phragmites australis under zinc pollution. J Plant Physiol 165:697-704.

140. Johnson CC, Fordyce FM, Rayman MP (2010) Symposium on 'Geographical and geological influences on nutrition' Factors controlling the distribution of selenium in the environment and their impact on health and nutrition. Proc Nutr Soc 69:119-132.

141. Jóźwiak W, Politycka B, (2019) Effect of Selenium on Alleviating Oxidative Stress Caused by a Water Deficit in Cucumber Roots. Plants 8:217.

142. Kabata Pendias A (2001) Trace elements in soils and plants. 3rd ed. Boca Raton (FL): CRC Press, $241-252$.

143. Kartusch R (2003) On the mechanism of callose synthesis induction by metal ions in onion epidermal cells.

Protoplasma 220:219-225. 
144. Karuppanapandian T, Moon JC, Kim C, Manoharan K, Kim W (2011) Reactive oxygen species in plants: their generation, signal transduction, and scavenging mechanisms. Australian Journal of Crop Science 5:709-725.

145. Kaur N, Sharma S, Kaur S, Nayyar H (2014) Selenium in agriculture: a nutrient or contaminant for crops? Arch Agron Soil Sci 60:1593-1624.

146. Kádár I (1998) A szennyezett talajok vizsgálatáról. In: Németh T (Eds) Kármentesítési kézikönyv 2. Környezetvédelmi Minisztérium, Budapest.

147. Keszler A, Zhang Y, Hogg N (2010) Reaction between nitric oxide, glutathione, and oxygen in the presence and absence of protein: how are S-nitrosothiols formed? Free Rad Biol Med 48:55-64.

148. Kim HY, Gladyshev VN (2005) Different catalytic mechanisms in mammalian selenocysteine- and cysteinecontaining methionine-R-sulfoxide reductases. PLoS Biol. 3:e375.

149. Kolbert Zs, Feigl G, Bordé Á, Molnár Á, Erdei, L (2017) Protein tyrosine nitration in plants: present knowledge, computational prediction and future perspectives. Plant Physiol Biochem 113:56-63.

150. Kolbert Zs, Feigl G, Freschi L, Poór P (2019b) Gasotransmitters in action: Nitric oxide-ethylene crosstalk during plant growth and abiotic stress responses. Antioxidants 8:167.

151. Kolbert Zs, Lehotai N, Molnár Á, Feigl G (2016) "The roots" of Se toxicity: a new concept. Plant Signal Behav 11:e1241935.

152. Kolbert Zs, Molnár Á, Feigl G, Van Hoewyk D (2019a) Plant selenium toxicity: Proteome in the crosshairs. Journal of Plant Physiology 232:291-300.

153. Kolbert Zs, Molnár Á, Oláh D, Feigl G, Horváth E, Erdei L, Ördög A, Rudolf E, Barth T, Lindermayr C (2019c) $\mathrm{S}-$ Nitrosothiol signaling is involved in regulating hydrogen peroxide metabolism of zinc-stressed Arabidopsis. Plant Cell Physiol 60:2449-2463

154. Kolbert Zs, Pető A, Lehotai N, Feigl G, Ördög A, Erdei L (2012) In vivo and in vitro studies on fluorophorespecificity. Acta Biol Szeged 56:37-41.

155. Kovács B, Széles É, Simon L, Győri Z (2008) Szeléntartalom vizsgálata tartamkisérletekben. Talajvédelem különszám 275-280.

156. Kovács I, Holzmeister C, Wirtz, M, Geerlof A, Fröchlich T, Römling G (2016) ROS-mediated inhibition of Snitrosoglutathione reductase contributes to the activation of anti-oxidative mechanisms. Front Plant Sci 7:1669.

157. Krzesłowska M (2011) The cell wall in plant cell response to trace metals: polysaccharide remodeling and its role in defense strategy. Acta Physiologiae Plantarum 33:35-51

158. Krzeslowska M, Lenartowska M, Mellerowicz EJ, Samardakiewicz S, Wosny A (2009) Pectinous cell wall thickenings formation-a response of moss protonema cells to Pb. Environ Exp Bot 65:119-131.

159. Krzeslowska M, Lenartowska M, Samardakiewicz S, Bilski H, Wosny A (2010) Lead deposited in the cell wall of Funaria hygrometrica protonema is not stable-a remobilization can occur. Environ Pollut 158:325-338.

160. Lancaster JR (2015) Nitric oxide: A brief overview of chemical and physical properties relevant to therapeutic applications. Future Sci OA:1.

161. Le Gall H, Philippe F, Domon JM, Gillet F, Pelloux J, Rayon C (2015) Cell wall metabolism in response to abiotic stress. Plants (Basel), 4:112-166.

162. Lehotai N, Feigl G, Koós Á, Molnár Á, Ördög A, Pető A, Erdei L, Kolbert Zs (2016a) Nitric oxide-cytokinin interplay influences selenite sensitivity in Arabidopsis. Plant Cell Rep http://dx.doi.org/10.1007/s00299-016-2028$\underline{5}$.

163. Lehotai N, Kolbert Zs, Peto A, Feigl G, Ördög A, Kumar D, Tari I, Erdei L (2012) Selenite-induced hormonal and signalling mechanisms during root growth of Arabidopsis thaliana L. J Exp Bot 63:5677-5687.

164. Lehotai N, Lyubenova L, Schröder P, Feigl G, Ördög A, Szilágyi K, Erdei L, Kolbert Zs (2016b) Nitro-oxidative stress contributes to selenite toxicity in pea (Pisum sativum L). Plant Soil 400:107-122.

165. Lehotai N, Petö A, Erdei L, Kolbert Zs (2011) The effect of Se (Se) on development and nitric oxide levels in Arabidopsis thaliana seedlings. Acta Biol. Szeged 55:105-107.

166. Li HF, McGrath SP, Zhao FJ (2008) Selenium uptake, translocation and speciation in wheat supplied with selenate or selenite. New Phytol 178:92-102.

167. Li J, Zhong R, Palva P (2017) WRKY70 and its homolog WRKY54 negatively modulate the cell wall-associated defenses to necrotrophic pathogens in Arabidopsis. PLoS ONE 12, Article ID e0183731.

168. Li T, Yang X, Lu L, Islam E, He Z (2009) Effects of zinc and cadmium interactions on root morphology and metal translocation in a hyperaccumulating species under hydroponic conditions. J Hazard Mat 169:734-741.

169. Lindermayr C (2018) Crosstalk between reactive oxygen species and nitric oxide in plants: key role of Snitrosoglutathione reductase. Free Rad Biol Med 122:110-115.

170. Lindermayr C, Saalbach G, Durner J (2005) Proteomic identification of S-nitrosylated proteins in Arabidopsis. Plant Physiol 137:921-930. 
171. Liu D, Li H, Wang Y, Ying Z, Bian Z, Zhu W, Liu W, Yang L, Jiang D (2017) How exogenous Se affects anthocyanin accumulation and biosynthesis-related gene expression in purple lettuce? Pol J Environ Stud 26:717722.

172. Liu K, Cai M, Hu C, et al. (2019)Selenium (Se) reduces Sclerotinia stem rot disease incidence of oilseed rape by increasing plant Se concentration and shifting soil microbial community and functional profiles. Environmental Pollution $254 \mathrm{Pt}$ B

173. Liu KF, Yeh MS, Kou GH, Cheng W, Lo CF (2010) Identification and cloning of a selenium dependent glutathione peroxidase from tiger shrimp, Penaeus monodon, and its transcription following pathogen infection and related to the molt stages. Dev Comp Immunol 34:935-944.

174. Liu Y, Wang L, Liu H, Zhao R, Liu B, Fu Q, Zhang Y (2016) The antioxidative defense system is involved in the premature senescence in transgenic tobacco (Nicotiana tabacum NC89). Biological Research 49:1.

175. Llugany M, Massot N, Wissemeier AH, Poschenrieder C, Horst WJ, Barceló J (1994) Aluminium tolerance of maize cultivars as assessed by callose production and root elongation. J Plant Nutr Soil Sci 157:447-451.

176. Loix C, Huybrechts M, Vangronsveld J, Gielen M, Keunen E, Cuypers A (2017) Reciprocal interactions between cadmium-induced cell wall responses and oxidative stress in plants. Front. Plant Sci., 8:1867

177. Lombardi L, Sebastiani L (2005) Copper toxicity in Prunus cerasifera: growth and antioxidant enzymes responses of in Vitro grown plants. Plant Science 168:797-802.

178. López-Huertas E, Corpas JF, Sandalio ML, del Rio LA (1999) Characterization of membrane polypeptides from pea leaf peroxisomes involved in superoxide radical generation. Biochem J 337:531-536.

179. Luna R, Pastor V, Robert J, Flors V, Mauch-Mani B, Ton J (2011) Callose deposition: a multifaceted plant defense response. Mol Plant Microbe Interact 24:183-193.

180. Lv X, Li H, Chen X, Xiang X, Guo Z, Yu J, Zhou Y (2018) The role of calcium-dependent protein kinase in hydrogen peroxide, nitric oxide and ABAdependent cold acclimation. Journal of Experimental Botany 69:41274139.

181. Lyons GH, Stangoulis JCR, Graham RD (2005) Tolerance of wheat (Triticum aestivum L.) to high soil and solution selenium levels. Plant Soil 270:179-188.

182. Maksimović I, Kastori R, Krstić L, Luković J (2007) Steady presence of cadmium and nickel affects root anatomy, accumulation and distribution of essential ions in maize seedlings. Biol Plant 51:589-592.

183. Malerba M, Cerana R (2018) Effect of Selenium on the Responses Induced by Heat Stress in Plant Cell Cultures. Plants 7:64.

184. Malik JA, Kumar S, Thakur P, Sharma S, Kaur N, Kaur R, Pathania DS, Bhandhari K, Kaushal N, Singh K, Srivastava A, Nayyar H (2011) Promotion of growth in mungbean (Phaseolus aureus Roxb.) by selenium is associated with stimulation of carbohydrate metabolism. Biol Trace Elem Res 143:530-539.

185. Martens DA (2003) Selenium. In: Stewart BA, Howell T (Eds) Encyclopedia of Water Science, Basel: Marcel Decker Inc., New York, 840-842.

186. Mata-Pérez C, Sánchez-Calvo B, Begara-Morales JC, Carreras A, Padilla MN, Melguizo M, Valderrama R, Corpas FJ, Barroso JB (2016b) Nitro-linolenic acid is a nitric oxide donor. Nitric Oxide 5:57-63.

187. Mata-Pérez C, Sánchez-Calvo B, Padilla MN, Begara-Morales JC, Luque F, Melguizo M, Jiménez-Ruiz J, FierroRisco J, Peñas-Sanjuán A, Valderrama R, Corpas FJ, Barroso JB (2016a) Nitro-fatty acids in plant signaling: Nitrolinolenic acid induces the molecular chaperone network in Arabidopsis. Plant Physiol 170:686-701.

188. Mehdawi AFE, Pilon-Smits EAH (2012) Ecological aspects of plant selenium hyperaccumulation. Plant Biol $14: 1-10$.

189. Mikkelsen RL, Haghnia GH, Page AL (1989) Factors affecting selenium accumulation by crop plants. Jacobs LW,(ed) Selenium in agricultural and the environment. Madison, WI: American Society of Agronomy and Soil Science Society of America 65-93.

190. Montes-Bayón M, LeDuc DL, Terry N, Caruso JA (2002) Selenium speciation in wild-type and genetically modified Se accumulating plants with HPLC separation and ICP-MS/ES-MS detection. J Anal At Spectrom 17: $872-879$.

191. Nappi AJ, Vass E, Frey F, Carton Y (2000) Nitric oxide involvement in Drosophila immunity. Nitric oxide 4:423-430.

192. Neuhierl B, Bock A (1996) On the mechanism of selenium tolerance in selenium-accumulating plants: purification and characterization of a specific selenocysteine methyltransferase from cultured cells of Astragalus bisulcatus. Eur J Biochem 239:235-238.

193. Pagnussat GC, Lanteri ML, Lombardo MC, Lamattina L (2004) Nitric oxide mediates the indole acetic acid induction activation of a mitogen-activated protein kinase cascade involved in adventitious root development. Plant Physiol 135:279-286. 
194. Palmer RM, Ferrige AG, Moncada S (1987) Nitric oxide release accounts for the biological activity of endothelium-derived relaxing factor. Nature 327:524-526.

195. Palms JM, Corpas FJ, del Río LA (2009) Proteome of plant peroxisomes: newperspectives on the role of these organelles in cell biology. Proteomics 9:2301-2312.

196. Pazurkiewicz-Kocot K, Galas W, Kita A (2003) The effect of selenium on the accumulation of some metals in Zea mays L. plants treated with indole-3-acetic acid. Cell Mol Biol Lett 8:97-103.

197. Pelloux J, Rusterucci C, Mellerowicz EJ, New insight into pectin methylesterase structure and function. Trends Plant Sci 12:1363-1372.

198. Peng A, Xu Y, Wang ZJ (2001) The effect of fulvic acid on the dose effect of selenite on the growth of wheat. Biol Trace Elem Res 83:275-279.

199. Pilon-Smits EAH (2019) On the Ecology of Selenium Accumulation in Plants. Plants 8:197.

200. Pilon-Smits EAH, de Souza MP, Hong G, Amini A, Bravo RC, Payabyab ST, Terry N (1999) Selenium volatilization and accumulation by twenty aquatic plant species. J Environ Qual 28:1011-1018.

201. Pilon-Smits EAH, Quinn CF, (2010): Selenium Metabolism in Plants; In: Hell R, Mendel RR (eds.), Cell Biology of Metals and Nutrients. Plant Cell Monographs, 17:225-241.

202. Piršelová B, Mistríková V, Libantová J, Moravčíková J, Matušíková I (2012) Study on metal-triggered callose deposition in roots of maize and soybean. Biologia 67:698-705.

203. Pokora W, Aksmann A, Baścik-Remisiewicz A, Dettlaff-Pokora A, Rykaczewski M, Gappa M, Tukaj Z (2017) Changes in nitric oxide/hydrogen peroxide content and cell cycle progression: study with synchronized cultures of green alga Chlamydomonas reinhardtii. Journal of Plant Physiology 208:84-93.

204. Polec-Powlak K, Ruzik R, Lipiec E, Ciurzynska M, Gawronska H (2007) Investigation of Pb(II) binding to pectin in Arabidopsis thaliana. J Anal Atom Spectrom 22:968-972.

205. Pompella A, Maellaro E, Casini AF, Comporti,M (1987) Histochemical detection of lipid peroxidation in the liver of bromobenzene-poisoned mice. Am J Pathol 129:295-301.

206. Potters G, Pasternak TP, Guisez Y, Palme KJ, Jansen MAK (2007) Stress-induced morphogenic responses: growing out of trouble? Trends Plant Sci 12:98-105.

207. Price A H (1990) A possible role for calcium in oxidative plant stress. Free Radic Res Commun 10:345-349.

208. Puyaubert J, Fares A, Rézé N, Peltier JB, Baudouin E (2014) Identification of endogenously S-nitrosylated proteins in Arabidopsis plantlets: Effect of cold stress on cysteine nitrosylation level. Plant Sci 215-216, 150-156.

209. Rahmat S, Hajiboland R, Sadeghzade N (2017) Selenium delays leaf senescence in oilseed rape plants. Photosynthetica 55:338-350.

210. Rahoui S, Martinez Y, Sakouhi L, Ben C, Rickauer M, Rickauer M, Ferjani EE, Gentzbittel L, Chaoui A (2017) Cadmium-induced changes in antioxidative systems and differentiation in roots of contrasted Medicago truncatula lines. Protoplasma 254:473-489.

211. Ramos SJ, Faquin V, Guilherme LRG, Castro EM, Ávila FW, Carvalho GS, Bastos CEA, Oliveira C (2010) Selenium biofortification and antioxidant activity in lettuce plants fed with selenate and selenite. Plant Soil Environ 56(12):584-588.

212. Rockel P, Strube F, Rockel A, Wildt J, Kaiser WM (2002) Regulation of nitric oxide (NO) production by plant nitrate reductase In Vivo and In Vitro. J Exp Bot 53:103-110.

213. Rodrigues O, Reshetnyak G, Grondin A, Saijo Y, Leonhardt N, Maurel C, Verdoucq L (2017) Aquaporins facilitate hydrogen peroxide entry into guard cells to mediate ABA- and pathogen-triggered stomatal closure. Proceedings of the National Acadamy of Sciences of the United States of America 114:9200-9205.

214. Sabbagh M, Van Hoewyk D (2012) Malformed selenoproteins are removed by the ubiquitin-proteasome pathway in Stanleya pinnata. Plant Cell Physiol 53:555-564.

215. Safia Habib, Asif Ali (2011) Biochemistry of Nitric Oxide Ind J Clin Biochem 26:3-17.

216. Sanz-Luque E, Ocaña-Calahorro F, Llamas A, Galvan A, Fernandez E (2013) Nitric oxide controls nitrate and ammonium assimilation in Chlamydomonas reinhardtii. J Exp Bot 64:3373-3383.

217. Sarkar TS, Biswas P, Ghosh KS, Ghosh S (2014) Nitric oxideproduction by necrotrophic pathogen Macrophomina phaseolina and the host plant in charcoal rot disease of jute: complexity of theinterplay between necrotroph-host plant interactions. PLoS One 9:e107348.

218. Scandalios JG (1997) Oxidative Stress and the Molecular Biology of Antioxidant Defenses, Cold Spring Harbor Laboratory Press, Plainview, NY, USA.

219. Scandalios JG (2005) Oxidative stress: molecular perception and transduction of signals triggering antioxidant defense genes. Brazilian Journal of Medical and Biological Research 38:995-1014.

220. Schiavon M, Pilon-Smits EAH (2017) The fascinating facets of plant Se accumulation-biochemistry, physiology, evolution and ecology. New Phytol 213:1582-1596. 
221. Schützendübel A, Polle A (2002) Plant responses to abiotic stresses: heavy metal-induced oxidative stress and protection by mycorrhization. J of Exp Bot 53:1351-1365.

222. Sehrawat A, Deswal R (2014) S-nitrosylation analysis in Brassica juncea apoplast highlights the importance of nitric oxide in cold-stress signaling. J Proteome Res 13:2599-2619.

223. Seymour JL, Lazarus RA (1989) Native gel activity stain and preparative electrophoretic method for the detection and purification of pyridine nucleotide-linked dehydrogenases. Anal Biochem 178:243-247.

224. Sharma PI, Jha AB, Dubey RS, Pessarakli M (2012) Reactive oxygen species, oxidative damage, and antioxidative defense mechanism in plants under stressful conditions. Journal of Botany Article ID 217037.

225. Sharma S, Bansal A, Dhillon SK, Dhillon K (2010). Comparative effects of selenate and selenite on growth and biochemical composition of rapeseed (Brassica napus L.). Plant Soil 329-339.

226. Shibagaki N, Rose A, McDermott JP, Fujiwara T, Hayashi H, Yoneyama T, Davies JP (2002) Selenate-resistant mutants of Arabidopsis thaliana identify Sultr1; 2, a sulfate transporter required for efficient transport of sulfate into roots. Plant J 29:475-486.

227. Shinmachi F, Buchner P, Stroud LJ, Parmar S, Zhao FJ, McGrath SP, Hawkesford MJ (2010) Influence of sulphur deficiency on the expression of specific sulphate transporters and the distribution of sulphur, selenium, and molybdenum in wheat. Plant Physiol 153:327-336.

228. Signorelli S, Corpas FJ, Borsani O, Barroso JB, Monza J (2013) Water stress induces a differential and spatially distributed nitro-oxidative stress response in roots and leaves of Lotus japonicus. Plant Sci 201:137-146.

229. Signorelli S, Corpas FJ, Rodriguez-Ruiz M, Valderrama R, Barroso JB, Borsani O, Monza J (2019) Drought stress triggers the accumulation of NO and SNOs in cortical cells of Lotus japonicus L. roots and the nitration of proteins with relevant metabolic function. Environmental and Experimental Botany 161:228-241.

230. Singh M, Singh N, Bhandari DK. 1980. Interaction of selenium and sulfur on the growth and chemical composition of raya. Soil Sci. 129:238-244.

231. Skinner CP (1999) Environmental Chemistry of Selenium. Soil Sci Soc Am J 164:70-72.

232. Smirnoff M (1995) Antioxidant systems and plant response to the environment. Environmental and plant metabolism: flexibility and acclimation. Bios Scientific Publishers, Oxford, UK, 217-243.

233. Smith GS, Watkinson JH (1984) Selenium toxicity in perennial ryegrass and white clover. New Phytol 97(4):557-564.

234. Sodum RS, Fiala ES (2001) Analysis of peroxynitrite reactions with guanine, xanthine, and adenine nucleosides by high-pressure liquid chromatography with electrochemical detection: C8-nitration and - oxidation. Chem Res Toxicol 14:438-50.

235. Souza JM, Peluffo G, Radi R (2008) Protein tyrosine nitration-Functional alteration or just a biomarker? Free Rad Biol Med 45:357-366.

236. Stöhr C, Strube F, Marx G, Ullrich WR, Rockel P (2001) A plasma membrane-bound enzyme of tobacco roots catalyses the formation of nitric oxide from nitrite. Planta 212:835-841.

237. Stöhr C, Ullrich WR (2002) Generation and possible roles of NO in plant roots and their apoplastic space. J Exp Bot 53:2293-2303.

238. Szuba A, Kasprowicz-Maluska A, Wojtaszek P (2015) Nitration of plant apoplastic proteins from cell suspension cultures. J Prot 120:158-168.

239. Takahashi M, Shigeto J, Sakamoto A, Izumi S, Asada K, Morikawa H (2015) Dual selective nitration in Arabidopsis: Almost exclusive nitration of PsbO and PsbP, and highly susceptible nitration of four non-PSII proteins, including peroxiredoxin II E. Electrophoresis 36:2569-2578.

240. Tamaoki M, Freeman JL, Pilon-Smits EAH (2008) Cooperative ethylene and jasmonic acid signaling regulates selenite resistance in Arabidopsis. Plant Physiol 146:1219-1230.

241. Tenhaken R (2014) Cell wall remodeling under abiotic stress. Front. Plant Sci., 5:771. https://doi.org/10.3389/fpls.2014.00771

242. Terry N, Carlson C, Raab TK, Zayed AM (1992) Rates of Se volatilization amongst crop species. J Environ Quality 21:341-344.

243. Terry N, Zayed AM, de Souza MP, Tarun AS (2000) Selenium in higher plants. Annu Rev Plant Physiol Plant Mol Biol 51:401-432.

244. Tuteja N, Gill SS, (2010) Reactive oxygen species and antioxidant machinery in abiotic stress tolerance in crop plants. Plant Physiology and Biochemistry 48:909-930.

245. Vaculík M, Konlechner K, Langer I, Adlassnig W, Puschenreiter M, Lux A, Hauser MT (2012) Root anatomy and element distribution vary between two Salix caprea isolates with different Cd accumulation capacities. Environ Pollut 163:117-126. 
246. Vaculík M, Lux A, Luxová M, Tanimoto E, Lichtscheidl I, (2009) Silicon mitigates cadmium inhibitory effects in young maize plants. Environ Exp Bot 67:52-58.

247. Valderrama R, Corpas FJ, Carreras A, Fernandez-Ocana A, Chaki M, Luque F, Gómez-Rodríguez MV, Colmenero-Varera P, del Río LA, Barroso JB (2007) Nitrosative stress in plants. FEBS Letters 581:453-461.

248. Van Hoewyk D (2013) A tale of two toxicities: malformed selenoproteins and oxidative stress both contribute to Se stress in plants. Ann Bot 112:965-972.

249. Van Hoewyk D (2016) Defects in endoplasmic reticulum-associated degradation (ERAD) increase selenate sensitivity in Arabidopsis. Plant Signal Behav 13: e1171451.

250. Van Hoewyk D, Garifullina GF, Ackley AR, Abdel-Ghany SE, Marcus MA, Fakra S, Ishiyama K, Inoue E, Pilon M, Takahashi H, Pilon-Smits EAH (2005) Overexpression of AtCpNifS enhances selenium tolerance and accumulation in Arabidopsis. Plant Physiol 139:1518-1528.

251. Van Hoewyk D, Takahashi H, Inoue E, Hess A, Tamaoki M, Pilon-Smits EAH (2008) Transcriptome analyses give insight into selenium-stress responses and selenium tolerance mechanisms in Arabidopsis. Physiol Plant 132:236-253.

252. Van Huysen T, Abdel-Ghany S, Hale KL, LeDuc D, Terry N, Pilon-Smits EA (2003) Overexpression of cystathionine- $\gamma$-synthase enhances Se volatilization in Brassica juncea. Planta 218:71-78.

253. Vollár M, Feigl G, Oláh D, Horváth A, Molnár Á, Kúsz N, Ördög A, Csupor D, Kolbert Z (2020) Nitro-Oleic Acid in Seeds and Differently Developed Seedlings of Brassica napus L. Plants 9:406.

254. Vuletic M, Hadsi-Taskovic Sukalovic V, Markovic K, Kravic N, Vucinic Z, Maksimovic V (2014) Differential response of antioxidative systems of maize roots cell walls to osmotic and heavy metal stress. Plant Biol 16:88-96.

255. Wallenberg M, Olm E, Hebert C, Björnstedt M, Fernandes AP (2010) Selenium compounds are substrates for glutaredoxins: a novel pathway for selenium metabolism and a potential mechanism for selenium-mediated cytotoxicity. Biochem J 429:85-93.

256. Wang H, Shan XQ, Wen B, Zhang S, Wang ZJ (2004) Responses of antioxidative enzymes to accumulation of copper in a copper hyperaccumulator of Commoelina communis. Archives of Environmental Contamination and Toxicology 47:185-192.

257. White PJ, Bowen HC, Parmaguru P, Fritz M, Spracken WP (2004) Interactions between selenium and sulphur nutrition in Arabidopsis thaliana. J Exp Bot 55:1927-1937.

258. Willats WGT, Knox JP, Mikkelsen JD (2006) Pectin: New insights into an old polymer are starting to gel. Trends Food Sci Technol 17:97-104.

259. Wimalasekera R, Villar C, Begum T, Scherer GFE (2011) Copper Amine Oxidase1 (CuAO1) of Arabidopsis thaliana contributes to abscisic acid-and polyamine-induced nitric oxide biosynthesis and abscisic acid signal transduction. Mol Plant 4:663-678.

260. Winkel-Shirley B (2002) Biosynthesis of flavonoids and effects of stress. Curr Opin Plant Biol 5:218-223.

261. Wu F, Chi Y, Jiang Z és mtsaik (2020) Hydrogen peroxide sensor HPCA1 is an LRR receptor kinase in Arabidopsis. Nature 578: 577-581.

262. Xia XJ, Zhou YH, Shi K, Zhou J, Foyer CH, Yu JQ (2015) Interplay between reactive oxygen species and hormones in the control of plant development and stress tolerance. Journal of Experimental Botany 66:2839-2856.

263. Xiao Q, Li XL, Gao GF, Chen J, Liu X, Shen ZJ, Zhu XY, Zheng HL (2017) Nitric oxide enhances selenium concentration by promoting selenite uptake by rice roots. J Plant Nutr Soil Sci 180:788-799.

264. Xie X, He Z, Chen N, Tang Z, Wang Q, Cai Y (2019). The roles of environmental factors in regulation of oxidative stress in plant. BioMed Research International Article ID 9732325.

265. Xu S, Guerra D, Lee U, Vierling E (2013) S-nitrosoglutathione reductases are low-copy number, cysteine-rich proteins in plants that control multiple developmental and defense responses in Arabidopsis. Front Plant Sci 4:430.

266. Xue TL, Hartikainen H, Piironen V (2001) Antioxidative and growth-promoting effect of selenium on senescing lettuce. Plant Soil 237:55-61.

267. Yu R, Kampschreur MJ, van Loosdrecht MCM, Chandran K (2010) Mechanisms and specific directionality of autotrophic nitrous oxide and nitric oxide generation during transient anoxia. Environ Sci Technol 44:1313-1319.

268. Yun BW, Feechan A, Yin M, Saidi NB, Le Bihan T, Yu M, Moore JW, Kang JG, Kwon E, Spoel SH, Pallas JA, Loake GJ (2011) S-Nitrosylation of NADPH oxidase regulates cell death in plant immunity. Nature 478:264-268.

269. Zavaliev R, Ueki S, Epel BL, Citovsky V (2011) Biology of callose ( $\beta$-1,3-glucan) turnover at plasmodesmata. Protoplasma 248:117-130.

270. Zayed A, Lytle CM, Terry N (1998): Accumulation and volatilization of different chemical species of selenium by plants; Planta 206:284-292.

271. Zelko I, Lux A, Sterckeman T, Martinka M, Kollárová K, Lišková D (2012) An easy method for cutting and fluorescent staining of thin roots. Ann Bot 110:475-478. 
272. Zembala M, Filek M, Walas S, Mrowiec H, Kornaś A, Miszalski Z, Hartikainen H (2010) Effect of selenium on macro- and microelement distribution and physiological parameters of rape and wheat seedlings exposed to cadmium stress. Plant Soil 329:457-468.

273. Zhang LH, Abdel-Ghany SE, Freeman JL, Ackley AR, Schiavon M, Pilon-Smits EAH (2006) Investigation of selenium tolerance mechanisms in Arabidopsis thaliana. Physiol Plant 128:212-223.

274. Zhang L, Ackley AR, Pilon-Smits EAH (2007) Variation in Se tolerance and accumulation among 19 Arabidopsis thaliana accessions. J Plant Physiol 64:327-336.

275. Zhang L, Hu B, Li W, Che R, Deng K, Li H, Yu F, Ling H, Li Y, Chu C (2014) OsPT2, a phosphate transporter, is involved in the active uptake of selenite in rice. New Phytol 201:1183-1191.

276. Zhang LH, Byrne PF, Pilon-Smits EAH (2006) Mapping quantitative trait loci associated with selenate tolerance in Arabidopsis thaliana. New Phytol 170:33-42.

277. Zhang S, Klessig DF (2001) MAPK cascades in plant defense signalling. Trends Plant Sci 6:520-527.

278. Zhang S, Melzer MM, Sen SN, Çelebi-Ölçüm N, Warren TH (2016) A motif for reversible nitric oxide interactions in metalloenzymes. Nat Chem 8:663-669.

279. Zhao Y, Man Y, Wen J, Guo Y, Lin J (2019) Advancesi n Imaging Plant Cell Walls. Trends Plant Sci 24(9):867878.

280. Zhou Y, Tang Q, Wu M, Mou D, Liu H, Wang S, Zhang Kikkert J, Berkelaar E (2013) Plant uptake and translocation of inorganic and organic forms of selenium. Arch Environ Contam Toxicol 65:458-465. 


\title{
IX. Összefoglalók
}

\author{
IX. 1. Magyar nyelvü
}

Kísérleteink során a különböző érzékenységű növényeket vettetük alá szelén kezelésnek, hogy felderítsük a tolerancia hátterében álló folyamatokat. A vizsgálatok során összehasonlítottuk az Brassica juncea, Arabidopsis thaliana, Astragalus bisulcatus és Astragalus membranaceus növényfajokat. A növények kezelése történhetett szelenittel vagy szelenáttala kísérleti rendszertől függően. Alkalmazott módszereink közé tartozott a növények növekedésének, biomasszájának és morfológiájának monitorozása, az életképesség, sejtfalváltozások és sztómaválasz tanulmányozása, a ROF és RNF metabolizmus változásainak valamint a proteintirozin nitrációnak a kimutatása.

Kísérleteink során a következő megállapítások születtek:

I. Bár nem esszenciális nyomelem számukra, minden vizsgált növényfaj képes volt nagy mennyiségü szelén akkumulációjára. A két szelénforma közül a szelenát rendelkezett magasabb transzlokációs rátával, mely mindhárom kezelt növényfajban megfigyelhető. A felvett szelén hatással volt az érzékeny Astragalus faj növények mikroelem-háztartására, hiszen a fontos tápelemek metabolizmusa, mint a vas, a cink, a mangán, a bór és a molibdén megváltozott.

II. A felvett szelén koncentrációtól függően kihatással volt a növények növekedésére és biomassza-produkciójára. A kisebb kezelési koncentráció több kísérleti rendszerben is pozitív hatású volt. Összességében elmondható, hogy a szelénérzékeny növények (Arabidopsis thaliana és Astragalus membranaceus) növekedését jelentősen gátolta a kezelés, melyhez számottevően csökkent toleranciaindex és gyökérmerisztémaéletképesség is társult. A toleráns és/vagy hiperakkumuláló növények (Brassica juncea és Astragalus bisulcatus) növekedése csupán a nagyobb szeléndózis hatására változott, melyhez egy bár csökkent, de az érzékeny növényfajokénál magasabb életképesség társult. A hajtásban a szelén akkumulációja nem változtatta meg jelentősen a levelek morfológiáját, nem jelentek meg nekrotikus vagy sárgulásos foltok. 
III. A gyökérnövekedés csökkenésének hátterében részben a toleranciamechanizmusok közé tartozó sejtfalmódosulások is állhattak, hiszen a sejtfal változásai megnövelhetik a rigiditását. A szelénérzékenyebb növények sejtfalában kallózszintézis történt a kezelések hatására, melyet a toleráns növényfajok nem mutattak. Ezekben a növényfajokban a sejtfalba lignin épült be és megváltozott a pektineloszlás, mely elösegíthette a növények toleranciáját. A szelén-kezelt indiai mustár levelei nagyszámú, nyitott sztómát tartalmaztak, mely a szelénvolatilizációval történő detoxifikációjára enged következtetni.

IV. A szelén prooxidánsként viselkedett a legtöbb kísérleti rendszerben, de ennek mértéke a növényfajok között eltérő volt. A kezelés megváltoztatta a $\mathrm{O}_{2}{ }^{--}$és $\mathrm{H}_{2} \mathrm{O}_{2}$ szinteket, de a változások az érzékeny növényfajokban jelentősebbek voltak, mint a toleránsaknál. Az oxidatív károsodások közül a lipidperoxidáció is ezt bizonyította. A különbség hátterében az ROF metabolizmusához köthető enzimek és antioxidánsok eltérő viselkedése állhat. A $\mathrm{O}_{2}{ }^{--}$-termelő NADPH-oxidáz aktivitása az érzékenyebb növényekben számottevően változott, valamint új izoenzimek is aktiválódtak. A kioltásért felelős SOD enzim aktivitását szintén befolyásolta a szelén, valamint az izoformái eltérő mértékben aktiválódtak. Összességében a SOD-aktivitás a toleráns növényfajokban volt magasabb a kísérletek folyamán. A sejtfali peroxidázok aktivitása is jelentősebb volt a türö növények gyökerében. A glutationtartalom növényfajonként eltérő választ mutatott: lúdfüben kissé megemelkedett, majd a legnagyobb kezelés csökkentette a szintet, míg az indiai mustárban a koncentrációfüggően csökkent, de ennek mértéke kisebb volt, mint a lúdfüben.

V. A RNF homeosztázisa szintén megváltozott a szelénkezelés hatására. A NO-szint nem változott jelentősen sem a szelénformákat összehasonlító kísérletben sem a keresztesvirágúak családjában. A csüdfüveket vizsgáló kísérletben az érzékenyebb $A$. membranaceus mindkét szervében megnövelte a NO-szintet, míg a hiperakkumuláló $A$. bisulcatus csak a hajtásában. Az ebből keletkező ONOO--szint szorosan kapcsolódott a szeléntoxicitáshoz. Minden szelénérzékeny növényfajban emelkedett a szintje, valamint a toxikusabb szelénforma, a szelenit is jelentősen növelte. A GSNO-szint s metabolizmusa szintén változott. A csüdfüvek családjában minden kezelési koncentráció jelentősen csökkentette a szintjét, kivéve az A. membranaceus sziklevelet, 
ahol ezzel ellentétesen, egy koncentráció-függő növekedés volt megfigyelhető. A bontásában szerepet játszó enzim, a GSNOR aktivitás csökkent az A. bisulcatus-ban, míg A. membranaceus-ban az aktivitás enyhén nőtt levélben.

VI. A peroxinitrit képes megváltoztatni a fehérjék ativitását tirozinnitráción keresztül, melyet a nitrozatív stressz biomarkereként is alkalmaznak. A szelenit jelentősen megváltoztatta a növények nitrációs mintáztatát a szelenáttal összehasonlítva, hajtásban maga a mintázat is változott az újonnan megjelent és csökkenő nitrációjú sávokkal, míg gyökérben csupán egy összesített nitrációs mintázat erősödés figyelhető meg. A lúdfü és indiai mustár kísérleti rendszerben mindkét növényfajban megnövekedett a nitráció intenzitása, de új nitrált fehérjesávok nem jelentek meg. A csüdfüvek családjában az A. membranaceus-ban jelentős nitrációs változások keletkeztek, számos új sáv jelent meg a gyökerekben, míg ezzel ellenétben az $A$. bisulcatus-ban inkább a nitráció csökkenéséről beszélhezünk, mivel egyes fehérjesávok nitrációja jelentősen csökken. Az eredmények alapján feltételezhető, hogy a fehérjék nitrációja és a szelén toxicitás között szoros kapcsolat van, valamint a tolerancia egyik mechanizmusa a módosított fehérjék lebontása.

Kísérleteink során sikerült fényt deríteni a szeléntoxicitás egy kevésbé vizsgált háttérfolyamatára, a nitro-oxidatív stresszre. A különböző növényfajokon és szelénformákkal végzett kísérletek több szempontból is bizonyították a folyamat jelentőségét stressz során, az eredmények pedig betekintést nyújtanak az igen összetett abiotikus stressz védelmi reakciókba, valamint a ROF és RNF homeosztázisába is.

Mivel az irodalom számára új eredményekről van szó, így véleményem szerint a munkám elősegítette a nitro-oxidatív stresszfolyamatok jobb megértését. Nem szabad azonban elfeledni, hogy más RNF-függő makromolekula módosítások (pl. lipid és nukleinsav nitráció) is történhetnek, így a jövőben ezek vizsgálata is megalapozott. 


\section{2. English summary}

In the course of my $\mathrm{PhD}$ studies I have been studying the background effects of selenium toxicity on different plant species. The research has been conducted using three experimental designs: in the first Indian mustard (Brassica juncea) was treated with different selenium forms to evaluate the differences in toxicity. In the second, two plant species were compared: Arabidopsis thaliana as a model plant and Brassica juncea as a heavy metal tolerant plant. Experiments were continued on selenium hyperaccumulator Astragalus bisulcatus and sensitive Astragalus membranaceus. Methods included growth parameters and biomass measurements, microscopic analysis of cell wall, stomatal responses, meristem viability, reactive oxygen- and nitrogen species. As a biomarker of nitro-oxidative stress, protein tyrosine nitration was visualized using immunohistochemistry and western blot.

The research data can be summarized as follows:

I.Selenium is a non-essential micronutrient for plants; however, as the effect of the treatments all plant species were capable to accumulate it. Selenate had much larger translocation rate, than selenite, most likely due to its slower metabolism and incorporation in seleno-amino acids in roots. The accumulated selenium disturbed the homeostasis of micronutrients, notably iron, zinc, manganese, boron and molybdenum in sensitive Astragalus plants.

II.The accumulated selenium changed the growth and biomass of plants. Small amounts of selenium could be beneficial, and in tolerant plant species, like Indian mustard and Astragalus bisulcatus it had beneficial effects on growth. Compared to this, selenium sensitive plants (Arabidopsis thaliana and Astragalus membranaceus) showed diminished growth and biomass, accompanied by the significant decrease in cell viability and tolerance index. Tolerant plant species suffered slight growth reduction in response to high concentrations of selenium. These plants showed milder reduction in meristem cell viability compared to other species. It is notable, that despite the large amount of accumulated selenium in the shoot, no visible symptoms like necrosis or chlorosis appeared on leaves. 
III.Plant tolerance and detoxification mechanisms include alterations in cell wall structure and composition. Sensitive plant species synthetized callose in response to selenium stress, which was not observable in tolerant species. The latter species altered the amount of lignin and pectin in the cell walls, probably effectively alleviating the effects of stress. Selenium-treated Brassica juncea leaves contained increased number of opened stomata suggesting Se detoxification via volatilization.

IV.As other abiotic stresses, also selenium can disturb the natural homeostasis of reactive oxygen species (ROS), resulting in oxidative signal transduction and oxidative macromolecule damage. Treatments altered the levels of $\mathrm{O}_{2}{ }^{--}$and $\mathrm{H}_{2} \mathrm{O}_{2}$ in all plant species, compared to control. These changes were more intense in sensitive species, resulting in increased macromolecule damage. Lipid peroxidation was used as a marker to evaluate ROS-induced macromolecule damage, and selenium increased it in a concentration dependent manner. NADPH oxidase is capable of producing large amounts of $\mathrm{O}_{2}^{--}$, resulting in an oxidative burst. In Astragalus membranaceus, treatments increased the activity of NADPH oxidase and several new isoenzymes were activated. Superoxide radical is quenched by SOD. In almost all plant species and experimental systems, changes in SOD activity were remarkable, especially with respect of the isoenzymes. Even if the total SOD activity was similar to control, the activity of SOD isoenzymes changed significantly in response to selenium. Cell wall peroxidases were also induced in response to the stress. Glutathione levels were altered in both Arabidopsis and Brassica juncea.

V.The homeostasis of reactive nitrogen species (RNS) has been less examined in selenium stress compared to the oxidative counterpart. In our study, NO levels were control-like in species of Brassicaceae family and increased in sensitive A. membranaceus. Moreover, A. bisulcatus cotyledons showed an increase in NO levels, but in roots no significant differences were detected. Peroxynitrite production was associated with selenium toxicity in all three experimental designs. In Astragalus membranaceus, a significant concentration-dependent $\mathrm{ONOO}^{-}$accumulation was observable contributing to selenium toxicity. Selenite treatment significantly increased $\mathrm{ONOO}^{-}$levels compared to selenate, where no notable differences were detected. S-nitrosoglutathione is a mobile NO storage being capable of nitrosative signalization in plant cells through 
posttranslational protein modifications. The levels of GSNO decreased in both organs of A. bisulcatus as the effect of selenium, in contrast cotyledons of A. membranaceus accumulated GSNO. Decomposition of GSNO is catalyzed by GSNOR enzyme. Its activity decreased in A. bisulcatus, in contrast A. membranaceus showed slightly increased GSNOR activity in the cotyledons.

VI.Protein tyrosine nitration is widely used as a biomarker of nitro-oxidative stress. To our understanding nitrated proteins are most likely inactivated, resulting in damage to the active protein pool. Selenite more intensively increased protein tyrosine nitration compared to selenate. In shoot, newly appeared nitrated protein band was observable in response to selenite treatment. Both Arabidopsis thaliana and Brassica juncea showed selenium-triggered increase in protein nitration, without significant changes to the pattern itself. Astragalus membranaceus suffered intense nitration, with several newly appeared nitrated protein bands on the membrane, suggesting a significant stress. The hyperaccumulator $A$. bisulcatus managed to decrease the number of nitrated protein bands, most likely via proteosomal degradation of malformed proteins. It is important to note that proteolysis could contribute to selenium tolerance by degradation of nonspecific selenoproteins. Our resulst suggest that protein tyrosine nitration and nitro-oxidative stress strongly contribute to selenium toxicity, supporting the importance of nitrosative posttranslational modifications in plant defense reactions.

Using different experimental designs and multiple examined species I demonstrated the importance of the process during stress and the results provide insight into the highly complex abiotic stress responses as well as the ROS and RNS homeostasis.

These data are new in international literature, and in my opinion those contributed to the better understanging of nitro-oxidative stress processes in plants. However, we should keep in mind that other RNS-dependent macromolecule modifications (e.g. lipid and nucleic acid nitration) may be involved, therefore their investigation is well-founded in the future. 


\section{Publikációs lista}

X. 1. Tudományos közlemények:

A doktori disszertációhoz tartozó három tudományos közleményt aláhúzással emeltem ki.

- Gábor Feigl, Devanand Kumar, Nóra Lehotai, Nóra Tugyi, Árpád Molnár, Attila Ördög, Ágnes Szepesi, Katalin Gémes, Gábor Laskay, László Erdei, Zsuzsanna Kolbert (2013)

Physiological and morphological responses of the root system of Indian mustard (Brassica juncea L. Czern.) and rapeseed (Brassica napus L.) to copper stress.

Ecotoxicology and Environmental Safety, 94 179-189

- Gábor Feigl, Nóra Lehotai, Árpád Molnár, Attila Ördög, Marta Rodríguez-Ruiz, José M. Palma, Francisco J. Corpas László Erdei, Zsuzsanna Kolbert (2015) Zinc induces distinct changes in the metabolism of reactive oxygen and nitrogen species (ROS and RNS) in the roots of two Brassica species with different sensitivity to zinc stress, Annals of Botany, 116: 613-625

- Gábor Feigl, Devanand Kumar, Nóra Lehotai, Árpád Molnár, Éva Rácz, Attila Ördög, László Erdei, Zsuzsanna Kolbert, Gábor Laskay (2015) Comparing the effects of excess copper in the leaves of Brassica juncea (L. Czern) and Brassica napus (L.) seedlings: growth inhibition, oxidative stress and photosynthetic damage, Acta Biologica Hungarica, 66 (2): 205-221

- Gábor Feigl, Zsuzsanna Kolbert, Nóra Lehotai, Árpád Molnár, Attila Ördög, Ádám Bordé, Gábor Laskay, László Erdei (2016) Different zinc sensitivity of Brassica organs is accompanied by distinct responses in protein nitration level and pattern Ecotoxicology and Environmental Safety, 125: 141-152

- Kolbert Zsuzsanna, Lehotai Nóra, Molnár Árpád, Feigl Gábor (2016) "The roots" of selenium toxicity: a new concept.

Plant Signaling and Behavior 11:(10) Paper e1241935.

- Lehotai Nóra, Feigl Gábor, Koós Ágnes, Molnár Árpád, Ördög Attila, Pető Andrea, Erdei László, Kolbert Zsuzsanna (2016) Nitric oxide-cytokinin interplay influences selenite sensitivity in Arabidopsis.

Plant Cell Reports 35:(10) pp. 2181-2195

- $\quad$ Zsuzsanna Kolbert, Gábor Feigl, Ádám Bordé, Árpád Molnár, László Erdei (2017) Protein tyrosine nitration in plants: Present knowledge, computational prediction and future perspectives.

Plant Physiology and Biochemistry 113 pp. 56-63

- Gábor Feigl, Ádám Bordé, Árpád Molnár, Zsuzsanna Kolbert (2018) Exogenous ascorbic acid is a pro-nitrant in Arabidopsis thaliana. 
ACTA BIOLOGICA SZEGEDIENSIS $62: 2$ pp. 115-122.

- $\quad$ Árpád Molnár, Gábor Feigl, Vanda Trifán, Attila Ördög, Réka Szőllősi, László Erdei, Zsuzsanna Kolbert (2018) The intensity of tyrosine nitration is associated with selenite and selenate toxicity in Brassica juncea $\mathrm{L}$.

Ecotoxicology and Environmental Safety, 147: 93-101

- $\quad$ Árpád Molnár, Zsuzsanna Kolbert, Krisztina Kéri, Gábor Feigl, Attila Ördög, Réka Szőllősi, László Erdei (2018) Selenite-induced nitro-oxidative stress processes in Arabidopsis thaliana and Brassica juncea

Ecotoxicology and Environmental Safety, 148: 664-674

- $\quad$ Zsuzsanna Kolbert, Árpád Molnár, Réka Szőllősi, Gábor Feigl, László Erdei, Attila Ördög (2018) Nitro-Oxidative Stress Correlates with Se Tolerance of Astragalus Species Plant and Cell Physiology, pcy099, 59: 9 pp. 1827-1843

- Gábor Feigl, Edit Horváth, Árpád Molnár, Dóra Oláh, Péter Poór, Zsuzsanna Kolbert (2019) Ethylene-Nitric Oxide Interplay During Selenium-induced Lateral Root Emergence in Arabidopsis

Journal of Plant Growth Regulation 38 pp. 1481-1488

- $\quad$ Kolbert Zsuzsanna, Molnár Árpád, Feigl Gábor, van Hoewyk Doug (2019) Plant selenium toxicity: Proteome in the crosshairs JOURNAL OF PLANT PHYSIOLOGY 232 pp. 291-300.

- Feigl Gábor, Molnár Árpád, Szőllősi Réka, Ördög Attila, Törőcsik Kitti, Oláh Dóra, Bodor Attila, Perei Katalin, Kolbert Zsuzsanna (2019) Zinc-induced root architectural changes of rhizotron-grown B. napus correlate with a differential nitro-oxidative response NITRIC OXIDE-BIOLOGY AND CHEMISTRY 90 pp. 55-65.

- Kolbert Zsuzsanna, Molnár Árpád, Oláh Dóra, Feigl Gábor, Horváth Edit, Erdei László, Ördög Attila, Rudolf Eva, Barth Teresa, Lindermayr Christian (2019) S-Nitrosothiol Signalling Is Involved In Regulating Hydrogen Peroxide Metabolism Of Zinc-Stressed Arabidopsis PLANT AND CELL PHYSIOLOGY 60: 11 pp. 2449-2463.

- Molnár Árpád, Papp Márk, Zoltán Kovács Dávid, Bélteky Péter, Oláh Dóra, Feigl Gábor, Szőllősi Réka, Rázga Zsolt, Ördög Attila, Erdei László, Rónavári Andrea, Kónya Zoltán, Kolbert Zsuzsanna (2020) Nitro-oxidative signalling induced by chemically synthetized zinc oxide nanoparticles (ZnO NPs) in Brassica species

CHEMOSPHERE 251 Paper: 126419

- Vollár Martin, Feigl Gábor, Oláh Dóra, Horváth Attila, Molnár Árpád, Kúsz Norbert, Ördög Attila, Csupor Dezső, Kolbert Zsuzsanna (2020) Nitro-Oleic Acid in Seeds and Differently Developed Seedlings of Brassica napus L.

Plants 9:406. 


\section{2. Konferencia-előadások:}

1. Gábor Feigl, Devanand Kumar, Andrea Pető, Nóra Lehotai, Attila Ördög, Árpád Molnár, Zsuzsanna Kolbert, László Erdei (2012) The effect of zinc on the microelement homeostasis and the metabolism of reactive signal molecules in Brassica juncea and Brassica napus.

Third Annual Workshop of COST Action FA 0905 - Mineral improved crop production for healthy food and feed, Lisbon, Portugal, 23-26 October 2012

2. Lehotai Nóra, Pető Andrea, Feigl Gábor, Ördög Attila, Tugyi Nóra, Molnár Árpád, Lyubenova L, Schröder Peter, Kolbert Zsuzsanna, Erdei László (2013) Selenium induced stress responses in Arabidopsis thaliana and Pisum sativum plants: the possibilities of biofortification.

Societas Biologiae Plantarum Hungarica, Conference of Young Biologists, Szeged, Hungary. 25 January 2013

3. Ördögné Dr. Kolbert Zsuzsanna, Feigl Gábor, Molnár Árpád, Prof Dr. Erdei László (2015) Growth responses induced by microelement excess: the role of reactive nitrogen species. Joint devenlopment of higher education and training programmes in plant biology in support of knowledge-based society opening conference, Szeged, Hungary, 20-21 April 2015

4. Molnár Árpád, Feigl Gábor, Bordé Ádám, Erdei László, Kolbert Zsuzsanna (2015), Különböző Brassica szervek cinkérzékenységének és eltérő protein nitrációjának kapcsolata. A Magyar Szabadgyök-Kutató Társaság VIII. Kongresszusa, Budapest, 2015. november 5-6.

5. Gábor Feigl, Ádám Bordé, Árpád Molnár, Zsuzsanna Kolbert (2016) Disturbance in RNS or ascorbate metabolism affects protein tyrosine nitration in Arabidopsis 6th Plant Nitric Oxide International Meeting. 78 p. Granada, Spanyolország, 2016 szeptember 14-16.

6. Molnár Árpád, Feigl Gábor, Szőllősi Réka, Erdei László, Kolbert Zsuzsanna (2017) Fehérje tirozin nitráció, mint a növényi szelénérzékenység markere Magyar Növénybiológiai Társaság Fiatal Növénybiológusok Előadássorozata, Debrecen, Magyarország, 2017. június 9.

7. Molnár Árpád, Feigl Gábor, Ördög Attila, Szőllősi Réka, Erdei László, Kolbert Zsuzsanna (2017) A fehérje nitráció szerepe a növényi szelén-érzékenységben

12th Congress of the Hungarian Society of Plant Biology, Szeged, Hungary, 30. August-1. September 2017

8. Molnár Árpád (2018) A szelén fitotoxicitás háttérfolyamatai különböző szeléntoleranciájú növényekben 
XXI. Tavaszi Szél Konferencia, Győr, Magyarország, 2018. május 4-6.

9. Zsuzsanna Kolbert, Árpád Molnár, Dóra Oláh, Attila Ördög, Eva Rudolf, Christian Lindermayr, Gábor Feigl (2018) Exogenous zinc modifies reactive nitrogen species metabolism in Arabidopsis

7th Plant Nitric Oxide International Meeting, Nice, France, 24-26 October 2018

10. Molnár Árpád (2019) Cink oxid nanopartikulumok hatása keresztesvirágú növényekre XXII. Tavaszi Szél Konferencia, Debrecen, Magyarország, 2018. május 3-5.

11. Feigl Gábor, Molnár Árpád, Oláh Dóra, Kolbert Zsuzsanna (2019) A fehérje tirozin nitráció mint az elemtöbblet által indukált nitro-oxidatív stressz indikátora növényekben Magyar Szabadgyök-Kutató Társaság X. Kongresszusa, Szeged, Magyarország, 2019. augusztus 29-30.

12. Molnár Árpád, Feigl Gábor, Papp Márk, Bélteky Péter, Rónavári Andrea, Kolbert Zsuzsanna (2019) Cink-oxid nanopartikulum-indukált nitro-oxidatív stressz Brassica növényekben

Magyar Szabadgyök-Kutató Társaság X. Kongresszusa, Szeged, Magyarország, 2019. augusztus 29-30.

\section{3. Konferencia-poszerek:}

1. Feigl G, Pető A, Lehotai N, Molnár Á, Erdei L, Kolbert Zs (2013) Comparison of the effect of copper and zinc in Brassica juncea and Brassica napus roots: Microelement homeostasis, metabolism of reactive signal molecules and morphological adaptation.

Biomedica Miniconference, 13 December 2013, Szeged, Hungary.

2. Feigl Gábor, Lehotai Nóra, Molnár Árpád, Erdei László, Kolbert Zsuzsanna (2014) Detection of protein tyrosine nitration in zinc-treated Brassica plants.

11th Congress of the Hungarian Society of Plant Biology, 27-29. August 2014, Szeged, Hungary

3. Molnár Árpád, Feigl Gábor, Lehotai Nóra, Erdei László, Kolbert Zsuzsanna (2014) Microscopic study of zinc localization in Brassica roots.

11th Congress of the Hungarian Society of Plant Biology, 27-29. August 2014, Szeged, Hungary

4. Molnár Árpád, Trifán Vanda, Feigl Gábor, Erdei László, Kolbert Zsuzsanna (2016)

Selenite treatment induces nitro-oxidative stress and decreases viability in indian mustard 22nd International Symposium on Analytical and Environmental Problems, Szeged, Hungary 2016. október 10 . 
5. Zsuzsanna Kolbert, Árpád Molnár, Gábor Feigl (2017) Selenium-infulenced root growth: the involvement of ethylene

VISCEA International Conference: Plant Nutrition, Growth \& Environment Interactions III., Bécs, Ausztria, 2017. február.20-21.

6. Molnár Árpád, Szőllősi Réka, Ördög Attila, Feigl Gábor, Kolbert Zsuzsanna (2017) In vivo fehérje tirozin nitráció szelén-kezelt Astragalus fajokban.

XV. Magyar Növényanatómiai Szimpózium, Budapest, Magyarország, 2017. szeptember 7.

7. Szőllősi Réka, Ördög Attila, Molnár Árpád, Feigl Gábor, Kolbert Zsuzsanna (2017) Anatómiai változások szelén-kezelt Astragalus fajok gyökerében.

XV. Magyar Növényanatómiai Szimpózium, Budapest, Magyarország, 2017. szeptember 7.

8. Feigl Gábor, Molnár Árpád, Krajner Jolán, Törőcsik Kitti, Kolbert Zsuzsanna (2017) Adaptation or inhibition - a rhizotron study on zinc-affected root growth of Brassica napus L. 12th Congress of the Hungarian Society of Plant Biology, Szeged, Hungary, 30. August-1. September 2017

9. Kolbert Zsuzsanna, Molnár Árpád, Poór Péter, Szőllősi Réka, Feigl Gábor (2017) The involvement of ethylene, stigolactones and nitric oxide in selenium-induced root morphogenic response (SIMR)

12th Congress of the Hungarian Society of Plant Biology, Szeged, Hungary, 30. August-1. September 2017

10. Véseiné Szőllősi Réka, Ördög Attila, Molnár Árpád, Feigl Gábor, Kolbert Zsuzsanna (2017) Szelén-kezelés okozta anatómiai változások Astragalus fajok gyökerében 12th Congress of the Hungarian Society of Plant Biology, Szeged, Hungary, 30. August-1. September 2017

11. Gábor Feigl, Nóra Lehotai, Árpád Molnár, Ádám Bordé, Zsuzsanna Kolbert (2017) Excess element-induced protein tyrosine nitration as the marker of nitrosative stress in plants 8th International Symposium on Root Development, Umeå, Svédország, 29. May-01. June 2017 12. Gábor Feigl, Árpád Molnár, Jolán Krajner, Dóra Oláh, Zsuzsanna Kolbert (2018) The effect of different vertical zinc distribution on the early root development and zinc accumulation of Brassica napus

24th International Symposium on Analytical and Environmental Problems, Szeged, Hungary October 8-9, 2018

13. Árpád Molnár, Gábor Feig1, Réka Szőllősi, Dóra Oláh, Attila Ördög, Zsuzsanna Kolbert (2018) The background processes of selenium-induced protein tyrosine nitration in Astragalus roots 
7th Plant Nitric Oxide International Meeting, Nice, France, 24-26 October 2018

14. Gábor Feigl, Árpád Molnár, Réka Szőllősi, Kitti Törőcsik, Dóra Oláh, Zsuzsanna Kolbert (2018) Distinct nitrosative response behind zinc-induced root architectural changes in Brassica napus L.

7th Plant Nitric Oxide International Meeting, Nice, France, 24-26 October 2018

13. Árpád Molnár, Gábor Feigl, Márk Papp, Dóra Oláh, Zsuzsanna Kolbert (2019) THE EFFECT OF ZINC OXIDE NANOPARTICLES ON ROS AND RNS METABOLISM OF BRASSICA ROOTS

14th International Conference on Reactive Oxygen and Nitrogen Species in Plants, München, Németország 2019. július 10-12.

14. Dóra Oláh, Árpád Molnár, Réka Szőllősi, Gábor Feigl, Zsuzsanna Kolbert (2019) NICKEL-INDUCED ROS AND RNS IMBALANCE IN BRASSICACEAE

14th International Conference on Reactive Oxygen and Nitrogen Species in Plants, München, Németország 2019. július 10-12.

15. Gábor Feigl, Árpád Molnár, Dóra Oláh, Ádám Czifra, Zsuzsanna Kolbert (2019) COMBINED HEAVY METAL TREATMENT AFFECTS NITRO-OXIDATIVE STATUS OF RAPESEED AND SUNFLOWER ROOTS DIFFERENTLY

14th International Conference on Reactive Oxygen and Nitrogen Species in Plants, München, Németország 2019. július 10-12.

16. Zsuzsanna Kolbert, Árpád Molnár, Dalma Ménesi, Ildikó Valkai, Taras Pasternak, Attila Fehér (2019) SIGNAL INTERACTION BETWEEN NITRIC OXIDE (NO) AND RHO GTPASES DURING ROOT GROWTH

14th International Conference on Reactive Oxygen and Nitrogen Species in Plants, München, Németország 2019. július 10-12.

17. Varga Viktória, Molnár Árpád, Kolbert Zsuzsanna, Feigl Gábor (2019) Két Alyssum lesbiacum populáció nikkelre adott válaszainak összehasonlítása nitrozatív paraméterek felhasználásával

Magyar Szabadgyök-Kutató Társaság X. Kongresszusa, Szeged, Magyarország, 2019. augusztus 29-30. 